Sandro Pinheiro de Souza Lemos

\title{
Nervo alógeno conservado em glicerol na regeneração de nervos periféricos: estudo experimental em ratos
}

Dissertação apresentada à Faculdade de Medicina da Universidade de São Paulo para obtenção do titulo de Mestre de Ciências

Área de concentração: Cirurgia Plástica

Orientador: Prof. Dr. Marcio Paulino Costa

São Paulo 
FICHA CATALOGRÁFICA 


\section{DEDICATÓRIA}

Aos meus pais Joaquim e Luzia, pelo apoio, carinho, dedicação e por proporcionarem a minha educação e formação.

A minha esposa Viviane pelo incentivo continuo, pelo carinho, pelo apoio nos momentos mais difíceis e pela compreensão nas minhas ausências. Também por ter-me proporcionado este presente divino, nossa filha, Fernanda.

Ao Prof. Dr. Marcus Castro Ferreira pelo apoio incondicional, pela confiança depositada e pelos ensinamentos a mim proporcionados.

Ao Prof. Dr. Marcio Paulino Costa, pelo apoio incondicional, pelo incentivo, pela confiança, pela amizade e pelos ensinamentos a mim proporcionados. 


\section{AGRADECIMENTOS}

Ao meu amigo Dr. Armando dos Santos Cunha, pelo companheirismo, incentivo e ajuda na elaboração desta dissertação.

Aos meus irmãos Lauriana e Joaquim Luiz, pelo amor, carinho e amizade durante toda a minha vida e pelos maravilhos sobrinhos: Heitor, Sabrinna, Mariana, Pedro, Ana Luisa, Maria Clara e João, motivos de grande alegria e orgulho.

Ao meu cunhado Henrique, pelo grande exemplo de sabedoria, humildade, esforço e pela valorosa amizade.

Aos meus Sogros Helio e Rosa leda e meus cunhados Semana e Frederico, pela amizade, respeito e carinho contínuos.

Ao Dr. Célio Ferreira Leão, Regente do Serviço de Cirurgia Plástica da Santa Casa de Misericórdia de Goiânia, pelo exemplo profissional, pelos ensinamentos, pelo apoio, pela compreensão e amizade.

Ao Dr. Cassiano Lemos Pelix, Chefe do Serviço de Cirurgia Plástica da Santa Casa de Misericórdia de Goiânia, pelo exemplo profissional, pelos ensinamentos, pelo incentivo e pela amizade.

A Dra Antonia da Conceição Almeida, eximia cirurgia plástica, pela amizade, pela confiança, pelos ensinamentos, conselhos e por ter-me incentivado a minha paixão pela cirurgia plástica reconstrutora. 
Ao Dr. Reinaldo Carvelo Carvalho, pelos ensinamentos, pelo apoio e pelos conselhos em minha formação profissional.

Ao Dr. Orlando J. Oliveira, pelos ensinamentos, pelo apoio, pela amizade e pelos conselhos em minha formação profissional.

Ao Dr. Fabiano Inácio, cirurgião de Mão, pela amizade sincera, os bons conselhos e os bons anos de convivência juntos durante a pós-graduação.

Ao Prof. Dr. Luiz Carlos Ishida, exímio cirurgião plástico, pelos ensinamentos, pelo apoio, pela confiança e pela amizade.

Ao Prof. Dr. Jose Carlos Marques Faria, exímio cirurgião plástico e microcirurgião, pelo grande exemplo, pelos ensinamentos, pelo exemplo de incrível habilidade, pela confiança a mim depositada, pela amizade e incentivo. Ao Prof. Dr. Julio Morais Besteiro, pelo seu brilhantismo, pela sabedoria, pelo grande exemplo, pelos ensinamentos em microcirurgia e cirurgia plástica, pela amizade e pelo incentivo.

Ao Prof. Dr. Paulo Tuma Jr., pelo exemplo, pelos ensinamentos, pelos conselhos, pela amizade e pelo incentivo profissional.

Ao Dr. Araldo Ayres Monteiro, pelo exemplo profissional, pelos conselhos, pelo incentivo e pela amizade.

Ao Dr. Gean Paulo Scopel e a Dra Simone Orpheu pela amizade, pela convivência e pelo incentivo.

Ao Dr. Diego Murillo Solis, um grande amigo, a quem tive a honra de acompanhar em sua formação como estagiário estrangeiro de cirurgia plástica 
da Faculdade de Medicina da Universidade de São Paulo, pelos anos de convivência, pelo companheirismo e pelo incentivo.

Ao Dr. An Wan Ching, pela amizade e pelos ensinamentos nos últimos meses.

Aos Assistentes da Disciplina de Cirurgia plástica da Faculdade de medicina da Universidade de São Paulo pelos ensinamentos importantes na complementação do meu conhecimento em Cirurgia plástica e Microcirurgia.

Aos Residentes da Disciplina de Cirurgia Plástica da Faculdade de Medicina da Universidade de São Paulo pela convivência e amizade desde 2004 ate o momento atual, em especial a Luciano Diniz, Julio Grynglas, Fabrício Ribeiro, Thomas Benson, Flavio Nogueira, e Helio Alves.

A Secretaria Edna e as funcionaria Maria, RÔ e Silvana e ao funcionário Ronaldo do Laboratório de Microcirurgia Experimental (LIM4), pelo auxilio e apoio para a realização desta dissertação.

A funcionária Israelita do Centro Cirúrgico do Hospital das Clinicas pelo apoio e amizade durante meu período de estagio em Microcirurgia.

Ao Sr. Fabio Montesano pela realização da estatística desta dissertação de mestrado.

A Sra. Hanna A. Rothschild pela revisão do resumo em inglês desta dissertação de mestrado.

Ao Designer Sr. Marcio Nascimento pelas figuras desta dissertação de mestrado. 
Esta dissertação esta de acordo com as seguintes normas, em vigor no momento desta publicação:

Referências: adaptado de International Committe of Medical Journals Editors (Vancouver).

Universidade de São Paulo. Faculdade de Medicina. Serviço de Biblioteca e Documentação. Guia de apresentação de dissertações, teses e monografias. Elaborado por Annelise Carneiro da Cunha, Maria Julia de A. L. Freddi, Maria F. Crestana, Marinalva de Souza Aragão, Suely Campos Cardoso, Valeria Vilhena. São Paulo: Serviço de Biblioteca e Documentação; 2004.

Abreviatura dos títulos dos periódicos de acordo com List of Journals Indexed in Index Medicus. 
SUMÁRIO

Lista de figuras

Lista de tabelas

Lista de gráficos

Lista de abreviaturas

Lista de símbolos

Resumo

Summary

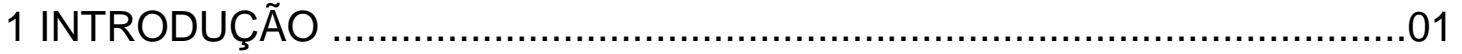

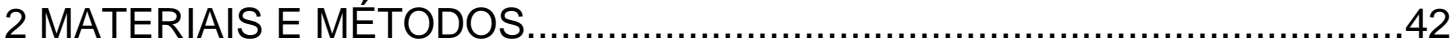

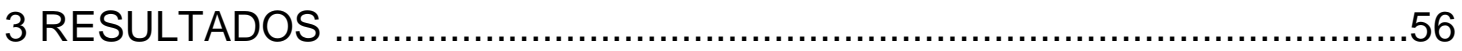

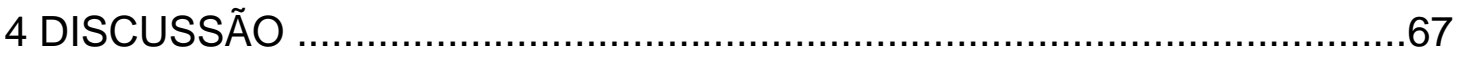

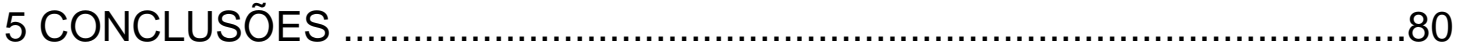

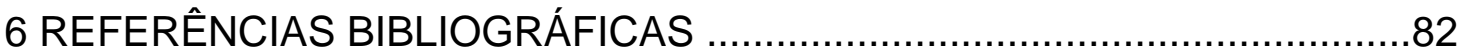




\section{LISTA DE FIGURAS}

Figura 1 - Classificação de lesões de nervos periféricos segundo Sunderland. (McCarthy JG. Plastic Surgery. Philadelphia :W B Saunders; 1990. v.1,p. 656)

Figura 2 - Representação esquemática: tronco do nervo ciático (NC), demonstrando suas ramificações: (NT) nervo tibial posterior, (NS) nervo sural e (NF) nervo fibular .44

Figura 3 - Ramificações do nervo ciático: (NT) nervo tibial posterior, (NS) nervo sural e (NF) nervo fibular. (10x) 45

Figura 4 - Demonstra a localização exata de secção do nervo fibular (NF) de 5 $\mathrm{mm}$ de comprimento e a $5 \mathrm{~mm}$ de sua origem no nervo ciático.Tronco do nervo ciático (NC), o nervo tibial posterior (NT) e o nervo sural (NS). 46

Figura 5 - Modelo esquemático demonstrando o reposicionamento do segmento de nervo autógeno previamente retirado através de sutura com fio monofilamentar de nylon 10.0. NC: nervo ciático, NF: nervo fibular, NS: nervo sural e NT: nervo tibial posterior.

Figura 6 - Modelo esquemático da região cervical anterior do rato, demonstrando a veia jugular externa (VJE) e a musculatura cervical superficial. (M) - Músculo Masseter; (D) - Músculo digástrico; (MSH) - Músculo esternohiodeo; (VFP) - Veia Facial Posterior; (VFA) - Veia Facial Anterior; (MC) - Músculo clavotrapezóide; (MEM) - Músculo esternocleidomastoideo. 
Figura 7 - Modelo esquemático da interposição de veia conservada em glicerol (grupo B) para tubulização de defeito de $5 \mathrm{~mm}$ em nervo fibular. Nota-se que o comprimento da veia é de $10 \mathrm{~mm}$ e que esta recobre $2,5 \mathrm{~mm}$ do coto proximal e 2,5 mm do coto distal, além da fixação em cada coto com ponto em "u".......50

Figura 8 - Modelo esquemático da interposição de nervo alógeno conservado em glicerol (grupo C) para tratamento de defeito de $5 \mathrm{~mm}$ em nervo fibular de rato Wistar, após sua retirada em rato doador de espécie diferente (SpragueDawley) e conservação por sete dias em glicerol a 98\% em refrigeração a $4{ }^{\circ} \mathrm{C}$ . NC: nervo ciático, NFS: nervo fibular de rato doador, NS: nervo sural e NT: nervo tibial posterior.

Figura 9 - Modelo esquemático demonstrando o reposicionamento do segmento de nervo alógeno previamente retirado de rato Sprague-Dawley, através de sutura com fio monofilamentar de nylon 10.0. NC: nervo ciático, NFS: nervo fibular de rato doador, NS: nervo sural e NT: nervo tibial posterior.

Figura 10 - Demonstram-se na impressão da pata do rato as medidas necessárias para quantificação do índice de função do nervo fibular. (De Medinaceli, 1982).

Figura 11 - Grupo A (auto-enxerto): escape de fibras regeneradas para fora dos limites do epineuro do auto-enxerto (200X). .57

Figura 12 - Grupo A (auto-enxerto). Minifascículos de axônios, em sua maioria, mielinizados e de variados diâmetros. (400x) 
Figura 13 - Grupo B (veia autógena + glicerol): corte histológico com presença de pequena reação tecidual perineural e escape axonal fora dos limites do

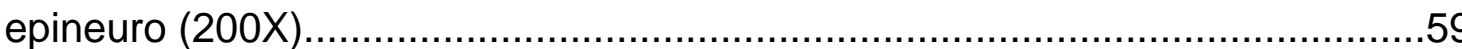

Figura 14 - Grupo B (Veia autógena + Glicerol): Demonstra-se minifascículos de axônios, a sua maioria mielinizada e de diâmetros variados. (400x). 59

Figura 15 - Grupo C (aloenxerto de Nervo + Glicerol): corte histológico com presença de pequena reação tecidual perineural e escape axonal fora dos limites do epineuro (200X)

Figura 16 - Grupo C (nervo alógeno + glicerol): Disposição dos axônios em minifascículos, em grande parte, mielinizados e de variados diâmetros (400x).

Figura 17 - Aspecto normal da pegada da pata traseira direita dos ratos no préoperatório (sem lesão do nervo fibular) 63

Figura 18 - Aspecto das pegadas dos ratos no pré e pós-operatório dos três grupos. 


\section{LISTA DE TABELAS}

Tabela 1 - Grupos experimentais com a distribuição dos animais de acordo

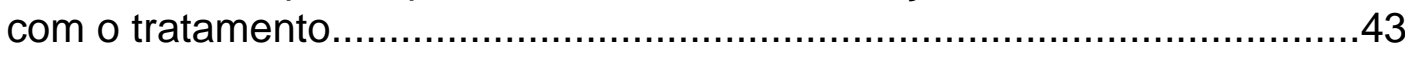

Tabela 2 - Medidas descritivas de IFF, em cada grupo, ao longo do tempo. 


\section{LISTA DE GRÁFICOS}

Gráfico 1- Perfis médios da variável IFF em cada grupo durante o tempo de estudo, iniciado no pré-operatório e o seguimento no pós-operatório imediato, 3

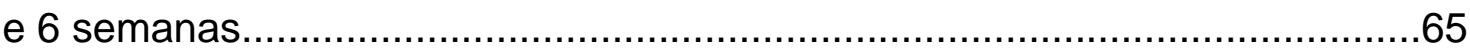




\section{LISTA DE ABREVIATURAS}

a.c antes de cristo

ACTH Hormônio adrenocorticotrófico

$\mathrm{CP} \quad$ comprimento de pegada

CPO comprimento de pegada da pata operada

CPN comprimento de pegada da pata não operada

D músculo digástrico

d.c depois de cristo

DP desvio padrão

Ed. Edição

ED extensão dos dedos

EDO extensão dos dedos da pata operada

EDN extensão dos dedos da pata não-operada

et al e outros

FK-506 Tacrolimus

GM1 Monossialotetraesosilgangliosídeo

HIV vírus da imunodeficiência humana

IFF índice de função do nervo fibular

LIM Laboratório de investigação médica

LINF linfonodos

M músculo masseter

MC músculo clavotrapezóide

MEM músculo esternocleidomastoideo

MSH músculo esternohiodeo

n número de animais

NC nervo ciático

NF nervo fibular 


$\begin{array}{ll}\text { NFS } & \text { segmento do nervo fibular } \\ \text { NGF } & \text { fator de crescimento neural } \\ \text { NS } & \text { nervo sural } \\ \text { NT } & \text { nervo tibial posterior } \\ \text { p } & \text { nível de significância } \\ \text { p. } & \text { página } \\ \text { PTFE } & \text { politetrafluoretileno } \\ \text { tAPG } & \text { tubo de ácido poliglicólico } \\ \text { USP } & \text { Universidade de São Paulo } \\ \text { VFA } & \text { veia facial anterior } \\ \text { VFP } & \text { veia facial posterior } \\ \text { VJE } & \text { veia jugular externa }\end{array}$




\section{LISTA DE SÍMBOLOS}

$\begin{array}{ll}\mathrm{cm} & \text { centímetro } \\ { }^{\circ} \mathrm{C} & \text { graus Celsius } \\ \mathrm{Kg} & \text { kilograma } \\ \mathrm{mm} & \text { milímetro } \\ \mathrm{mg} & \text { miligrama } \\ = & \text { igual a } \\ < & \text { menor }\end{array}$




\section{RESUMO}

Lemos SPS. Nervo alógeno conservado em glicerol na regeneração de nervos periféricos: Estudo experimental em ratos [dissertação]. São Paulo: Faculdade de Medicina, Universidade de São Paulo; 2008. 106p.

O tratamento cirúrgico mais utilizado para a reparação das lesões de nervos periféricos com perda de substância é através de auto-enxertia de nervo. Essa técnica produz alterações na área doadora e muitas vezes não se dispõe de tecido suficiente para grandes perdas de tecido neural. Desta forma é necessária a busca de novas técnicas, menos traumáticas e mais simples, visando eliminar a morbidade na área doadora e prover a quantidade necessária de tecido para a regeneração neural. $\mathrm{O}$ objetivo desse trabalho foi comparar, em ratos Wistar, o grau de regeneração neural, utilizando-se de análise histológica e análise funcional, através de interposição de enxerto autógeno de nervo (Grupo A), veia autógena conservada em glicerol (Grupo B) e enxerto alógeno de nervo conservado em glicerol (Grupo C) para correção de defeito de $5 \mathrm{~mm}$ de nervo fibular. Quinze ratos machos da raça Wistar, com peso variando entre 200 e $300 \mathrm{~g}$, e idade ao redor de oito semanas foram divididos em três grupos de cinco animais de acordo com o tratamento empregado. Para a coleta de segmentos de nervos alógenos, foram escolhidos cinco ratos da Raça Sprague-Dawley, com sexo, idade e peso semelhantes ao da raça Wistar. Os animais foram submetidos à avaliação funcional ("walking track analysis") imediata, com três semanas e com seis semanas e sacrificados 
para realização dos estudos histológicos com a coloração de tetróxido de ósmio. Na análise microscópica das lâminas, realizada, em todos os grupos foram visualizados pequenos fascículos contendo axônios mielinizados de tamanhos variados e degeneração Walleriana em pequeno número de axônios. Nos grupos B (Veia autógena conservada em glicerol) e C(Nervo alógeno conservado em glicerol) o escape de fibras axonais mielinizadas para fora dos limites do epineuro e o processo inflamatório local foram menores que o do grupo A (Auto-enxertia). Em relação à avaliação funcional, onde foi utilizada a análise estatística por meio do modelo de análise de variância com medidas repetidas e o de comparações múltiplas de Bonferroni $(p<0.05)$, não houve diferença estatisticamente significativa entre as recuperações funcionais do nervo fibular independente do tipo de reparação utilizada em nenhum período avaliado.

Descritores:

1. Transplantes 2. Regeneração nervosa 3. Glicerol 4. Nervo Fibular 5. Ratos Wistar 6. Cirurgia/ métodos 


\section{SUMMARY}

Lemos SPS. Allogenous nerve preserved in glycerol in the regeneration of peripheral nerves. Experimental study in rats [Master Thesis]. São Paulo, University of São Paulo Medical School, 2008. 106 p.

The most used surgical treatment of peripheral nerves for the repair of injuries with loss of substance is using nerve autograft. This technique produces alterations in the donor area and often not sufficient tissue is available for great losses of neural tissue. Thus the need for new less traumatic and simpler techniques is needed in order to eliminate morbidity in the donor area and to provide the necessary amount of tissue for neural regeneration. The objective of this study was to compare, in Wistar rats, the degree of neural regeneration, using histological and functional analysis through interposition of autogenous nerve graft (Group A), autogenous vein preserved in glycerol (Group B) and allogenous graft preserved in glycerol (Group C) for the correction of a 5-mm defect of fibular nerve. Fifteen male Wistar rats, weighing between 200 and 300 $\mathrm{g}$ and approximately 8 weeks old were divided into 3 groups of five animals according to the used treatment. For the collection of autogenous nerve segments 5 Sprague-Dawley rats were chosen, with similar sex and age as the Wistar rats. The animals were submitted to immediate functional evaluation (walking track analysis), at 3 and 6 weeks and sacrificed for histologic studies using osmium tetroxide stain. On microscopic analysis of the slides, performed in all groups, small fascicles containing myelinated axons of varied sizes and wallerian degeneration in a small number of axons were visualized. In Groups $B$ (autogenous vein preserved in glycerol) and C (allogenous nerve preserved in glycerol) escape of axonal myelinated fibers outside the limits of the epineurium and the local inflammatory process were less than in Group A (autograft). Regarding functional evaluation, where statistical analysis by variance analysis using the models of repeated measures and that of Bonferroni's multiple comparisons were used $(p<0.05)$ there was no statistically significant difference 
between functional recoveries of the fibular nerve independent of the type of repair used in any evaluated period.

Descritors:

1. Transplants 2. Glycerol 3. Nerve regeneration 4. Peroneal Nerve 5. Rats, Wistar 6. Surgery/ methods 



\section{INTRODUÇÃO}

O tratamento cirúrgico mais utilizado atualmente para a reparação das lesões de nervos periféricos com perda de substância é através da autoenxertia de nervo. Essa técnica consiste na interposição de um nervo autólogo entre as extremidades proximal e distal do nervo lesado e tem como objetivo o preenchimento do espaço entre os cotos, promovendo a diminuição da tensão nas linhas de sutura e a orientação para o avanço linear dos cones de crescimento neurais.

A auto-enxertia além de não promover a recuperação funcional total do nervo lesado produz alterações na área doadora (Spector et al, 1993 e Brunelli et al, 1994). Esses problemas associados a essa metodologia abrem caminho para a busca de novas técnicas que sejam menos traumáticas, mais simples e que possam eliminar os danos causados na área doadora e reduzir o tempo cirúrgico.

Uma dessas alternativas foram o uso das câmaras de tubulização e o emprego de outros substitutos para o reparo do nervo. Muitos materiais foram estudados como forma de tubulização, incluindo osso descalcificado (Glück et al, 1880), tubo de fáscia (Kirk et al, 1915), tubos sintéticos (Lundborg et al 1981 e 1982, Garrity et al, 1955) e tubos reabsorvíveis (Molander et al, 1983, Brunelli et al, 1991; Costa, 2006).

Também se utilizou vasos como forma de tubulização para reconstrução neural. Foramitti (1904) foi o primeiro a realizar o reparo nervoso com enxerto arterial seguido por Wrede (1909) que o fez por meio de enxerto venoso. 
Wolff e Dienemann (1990) e Wolff et al (1993) demonstraram que os vasos podem ser preservados em glicerol sem destruição de sua estrutura, o que permite seu uso na microcirurgia vascular.

Cunha e costa (2007) demonstraram que veias autógenas e alógenas conservadas em glicerol podem ser utilizadas como substitutos na regeneração neural, tendo resultados similares aos obtidos por auto-enxertia de nervo fibular para lesões de cinco $\mathrm{mm}$ em ratos Lewis.

Também foi comprovado por Wolff et al (1993) que o uso de enxertos alógenos de nervo femoral conservados em glicerol para defeitos de $12 \mathrm{~mm}$ mantiveram propriedades similares aos obtidos com os auto-enxertos.

Apesar dos trabalhos sobre o uso de tubulização com vasos preservados em glicerol como substitutos de auto-enxertos de nervo na literatura, pouco se têm do uso de enxertos alógenos de nervos conservados em glicerol para correção de defeitos neurais.

O objetivo deste trabalho foi comparar, em ratos, o grau de regeneração neural, utilizando-se de análise histológica e análise funcional, através de interposição de enxerto autógeno de nervo, veia autógena e enxerto alógeno conservados em glicerol na correção de defeito de $5 \mathrm{~mm}$ de nervo fibular..

Para melhor entendimento da revisão de literatura esta será realizada em três partes: 1 - Histórico; 2 - Fisiologia da lesão neural e sua reparação; 3 Conservação de tecidos em glicerol. 
1 - Histórico:

Galeno (460-370 a.c) foi o primeiro a relatar os efeitos da transecção de nervos periféricos através de experimentos simples, observando decréscimo de sensibilidade ou de motricidade após seccionar alguns nervos de pequenos animais.

Embora haja referências muito antigas a respeito do reparo de nervos lesados (Paulus de Aegineta, século VII d.c; Roger de Parma e William de Saliceto, século XII d.c), a rápida evolução do entendimento e também do tratamento das lesões nervosas iniciou-se nos séculos XIX e XX.

No fim do século 18, Galvani utilizando um microscópio óptico e através de experimentos em animais, demonstrou a importante relação entre nervos, contração muscular e estimulo elétrico.

Bell e Purkinje seguiram elucidando a intima relação entre conexões da raiz espinhal e axônios dos nervos periféricos. Waller fez uma descoberta importante sobre a degeneração axonal após lesão nervosa (1850), o que posteriormente ficou conhecido por Degeneração Walleriana.

Paralelamente a estas descobertas cientificas básicas, desenvolveu-se a primeira sutura primária bem sucedida de um nervo mediano, relatada por Paget (1847) e os experimentos de Vulpian com enxertos de nervos (1870).

Silas Weir Mitchell, através de sua vivência como médico militar durante a Guerra Civil Norte Americana, fez observações clinicas muito detalhadas e precisas a respeito de lesões nervosas (1872). 
De forma similar, pelo grande numero de casos de pacientes com lesões de nervos periféricos na $1^{\mathrm{a}}$ Grande Guerra Mundial, os estudos clínicos e a aplicação de técnicas de enxertos nervosos autólogos se intensificaram na primeira parte do século 20 com Mayo-Robson (1917), Delangeniere (1924) e Bunnell (1927). Nesta época, Wyeth e Taylor (1917, 1920) relataram resultados favoráveis com reparo por sutura primária de cotos de nervos.

A $2^{\mathrm{a}}$ Grande Guerra Mundial deu a Seddon e a outros estudiosos a oportunidade de investigar um largo espectro de lesões nervosas periféricas com as quais conduziram com tentativas de reparo primário e de enxertos de nervos autólogos. Saint Clair Strange reportou a primeira transferência de nervo com pedículo vascular para a reconstrução de grandes defeitos em 1947. Entretanto, resultados clínicos pobres desencorajaram a aceitação por outros cirurgiões à utilização desta técnica.

O advento da microcirurgia reconstrutiva dentro da cirurgia plástica desafiou o antigo conceito de que a reconstrução de nervos era algo inalcançável. Pode-se dizer que o fundamento básico na morfologia e fisiologia da lesão e da regeneração do nervo, foi obtido por experimentos realizados por Seddon (1947) e Sunderland (1945), qualificando os tipos de lesões de nervos e orientando a conduta apropriada para cada grau de lesão.

Surgia assim a classificação de Seddon e Sunderland para lesões de nervos periféricos que tem grande significado prático para o cirurgião plástico moderno.

Concomitantemente, o conhecimento obtido por Millesi (1975) e vários outros estudiosos em seus experimentos, trouxe uma melhor compreensão e 
aplicação dos princípios da microcirurgia aplicada ao reparo de nervos periféricos levando à melhores resultados no tratamento destas lesões.

Os estudos mais relevantes sobre as lesões de tecido neural e sobre a necessidade de pontes entre os cotos proximais e distais para permitir a sua regeneração datam da segunda metade do século XIX. O primeiro experimento com enxertia de nervos foi descrito por Phillipeaux e Vulpian em 1870.

Em 1873, foi feita a publicação por Heuter, do primeiro estudo sobre neurorrafia em lesões neurais prévias.

Já Glück, em 1880, descreveu a primeira anastomose com a utilização de tubulização, quando interpôs ossos descalcificados para a regeneração axonal.

Em 1901, Lotheissen descreveu uma técnica de tubulização com uso de gelatina para promover crescimento axonal.

Em 1904, Foramitti relatou uma regeneração neural bem sucedida utilizando tubulização com uso de enxerto arterial. Em 1909, Wrede realizou tubulização por meio de enxerto venoso.

Em 1915, Kirk e Lewis confeccionaram um tubo de fáscia para conduzir a regeneração neural. Em 1932, Ballance e Duel relataram a tubulização com de trompa de falópio para a regeneração de nervo facial.

Em 1941, Swan utilizou enxerto venoso na correção de lesão do nervo ulnar em humanos. Em 1943, Weiss usou tubos de artérias dissecadas para guiar a regeneração neural. 
Como os resultados obtidos foram pobres, estudos para a compreensão da fisiologia e anatomia dos nervos periféricos passaram a ser realizados. Sunderland (1945) contribuiu de forma importante para melhorar os resultados das neurorrafias.

Highet e Sanders procuraram estabelecer a importância da eliminação da tensão em reparos de nervos periféricos, seguidos por outros autores com os mesmos resultados (Denny-Brown e Doherty, 1945; Salvy, 1973; Terzis et al, 1975).

Foi creditada a Seddon, em 1947, a introdução do uso de enxerto de nervo em lesões extensas, onde a simples neurorrafia ocasionaria uma anastomose sob tensão, e, conseqüentemente, maus resultados. Este conceito foi em seguida ampliado na forma de segmentos de nervos com a vascularização ainda presente e ativa em uma técnica complexa e de resultados pobres (St. Clair Strange e Silverstone, 1947).

A inexistência de materiais de suturas adequados levou ao desenvolvimento de câmaras de tubulização ou neurotubos (estruturas cilíndricas que abrigariam em seu interior os cotos proximal e distal, com a finalidade de promover a regeneração) como meio alternativo para as neurorrafias.

Em 1955, Garrity relatou o uso de tubos plásticos como condutores para regeneração neural. Basset, em 1959, relatou a regeneração neural através de tubos amnióticos.

A introdução da magnificação da visão intra-operatória através de lupas e microscópios na reparação de nervos periféricos ocorreu nos anos 60 , e foi um 
marco na historia das técnicas de reparação de nervos, pois levou a uma significativa melhora qualitativa nos resultados (Jacobson et al, 1963; Gabrielson e Stenstrom, 1966; Wise et al, 1969; Stancic et al, 1998) e abriu um campo para novos estudos.

Mais recentemente, em 1981 e 1982, Lundborg e cols. desenvolveram novos estudos com a utilização de tubos sintéticos não-absorvíveis que são câmaras pré-fabricadas de silicone revestidas de mesotélio, nos quais ocorreu regeneração neural, mostrando a influência do neurotropismo no crescimento axonal.

Em 1982, Brunelli e cols. demonstraram a possibilidade de completa regeneração neural no interior de enxertos autólogos de veia em defeitos menores que um cm. Posteriormente, em 1987, demonstraram a atração quimiotática seletiva para fibras sensitivas e motoras através de enxerto de veia em defeitos menores que um $\mathrm{cm}$. A quimiotaxia seletiva foi posteriormente reproduzida por Ochi e cols. (1991) e Maki (1991).

Em 1983, Ide et al relataram a possibilidade de se usar uma fita circular de membrana basal de músculo esquelético para guiar a regeneração neural, hipótese já sugerida por Sanes e cols. em 1978.

Muitos outros pesquisadores continuaram os estudos em condutores musculares, usando fibras integras ou degeneradas (Davies, 1987; Fawcet e Keynes, 1986; Gattuso et al, 1988; Glasby et al, 1986; Jimming et al, 1986).

De uma maneira não rotineira no uso de câmaras de tubulização, Politis e cols. (1988) incorporaram um dispositivo produtor de corrente elétrica em um neurotubo e demonstraram que a aplicação de um campo de corrente elétrica 
melhora a regeneração neural. Embora há muito tempo já se tenha o conhecimento de que campos elétricos "in vitro" orientam e aceleram o crescimento de nervos (Jaffe, 1979; Patel e Poo, 1982), esse é o primeiro estudo sobre o efeito de campos bem orientados e localmente aplicados em um modelo cirúrgico de lesão neural. Apesar de este dispositivo ter promovido crescimento histologicamente perceptível, a sua eficácia funcional ainda não foi comprovada.

Walton et al, em 1989, descreveram os estudos com o uso de enxertos de veia no reparo de lesões de nervos digitais em intervalos de um a três $\mathrm{cm}$ obtendo resultados comparáveis aos casos controle (enxerto de nervo) que foi encontrado por outros autores (Chiu et al, 1982; Rice e Berstein, 1984). Essa técnica apresenta a desvantagem de ser mais susceptível ao colapso.

Estudos mais atuais têm sido realizados na tentativa de desenvolvimento de tubos sintéticos reabsorvíveis, entre eles, os de poliglactina (Molander et al, 1982; Molander et al, 1983) e diferentes tipos de ácido hialurônico (Brunelli, 1991).

A regeneração neural no interior de tubos de poliglactina foi relatada em 1990 por Mackinnon e Dellon. Hentz et al, em 1991, apresentaram um estudo comparativo entre a sutura primária e a tubulização fascicular com tubos de ácido poliglicólico, em primatas, onde um defeito de $1,5 \mathrm{~cm}$ era tratado com estas duas técnicas, concluindo não haver diferenças significativas entre elas.

Keeley, em 1991, realizou estudo com tubos de carbonato de trimetileno glicólico e, em 1993, Robinson e cols, apresentaram bons resultados com uma prótese de poliuretano biodegradável contendo ACTH4-9. 
Em 1999, Hazari et al, realizou estudo experimental em ratos com um tubo de poli-3-hidroxibutirato (PHB); no entanto, obteve resultados piores se comparados aos do auto-enxerto, relacionando-os com a falta de propriedades celulares do mesmo.

Brunelli, em 1993, realizou estudo com condutor venoso preenchido com músculo fresco autógeno e demonstrou a qualidade superior dos resultados para distancias até o dobro daquelas dos condutores preenchidos por axônios em tubos vazios.

Recentemente, alguns autores mostraram experimentalmente, vantagens do uso de veia invertida (ao avesso) em relação ao enxerto tradicional de veia (Wang et al, 1993) e também quando comparado com os enxertos de nervos (Wang et al, 1995). Segundo Wang, os enxertos de veia invertida possuem algumas vantagens teóricas. Foi demonstrado que o colágeno e a laminina facilitariam a regeneração neural nesses casos (Bryan et al, 1993; Colin e Donoff, 1994; Eppley e Delfino, 1988; Giorgio et al, 1993; Ide et al, 1990; Lander et al, 1985; Muller, 1988; Takahashi et al, 1988; Valentini et al, 1987).

A camada adventícia das veias é uma rica fonte de colágeno, e a camada muscular média das veias é rica em laminina. Invertendo-se a orientação normal das veias, ocorre uma melhor exposição dos axônios ao colágeno existente na camada adventícia. Alem disso, a camada adventícia posicionada internamente previne com maior eficiência o colapso da veia (Mattar et al, 1990; Wang et al, 1993), principal fator que prejudicaria sua utilização (Tang et al, 1993; Chui e Strauch, 1990; Walton et al, 1989). 
Em nosso meio, Costa foi o pioneiro na realização de estudos com a técnica de tubulização. Em 1995, comparou a regeneração entre a interposição de auto-enxerto de nervo e tubo de acido poliglicólico com e sem a presença de GM1, uma substância sabidamente neurotrófica, não encontrando diferenças quanto ao grau de regeneração neural em relação ao grupo controle (auto-enxertia) em defeitos de $5 \mathrm{~mm}$ de nervo ciático de ratos.

O mesmo autor, Costa (2006) utilizou tubo de ácido poliglicólico e administração subcutânea de FK506, um imunossupressor potente, que também tem a propriedade de estimulo ao crescimento dos brotos axonais. Demonstrou não haver diferenças entre a regeneração neural em animais tratados com auto-enxerto, tubulização com ácido poliglicólico com e sem a substância FK506 e auto-enxerto recoberto com tubo de ácido poliglicólico em defeitos de $5 \mathrm{~mm}$ de nervo ciático de ratos.

No ano de 2000, Kitahara et al demonstraram, em estudo experimental em gatos, resultados semelhantes aos do auto-enxerto com a utilização do tubo de colágeno obtido de pele suína, sugerindo a possibilidade de um reparo alternativo de lesões de nervos faciais em gatos de até $2 \mathrm{~cm}$.

Na última década, pacientes adultos submetidos à reconstrução com aproximação e sutura de cotos e à utilização de enxertos de nervos obtiveram resultados considerados excelentes em uma taxa que variou de 0 a $67 \%$ (Gould, 1991; Mackinnon e Dellon, 1988). A necessidade de que se melhore essa taxa impulsionou a medicina no sentido de se desenvolver novas técnicas, determinantes na eventual melhora da função (De Medinaceli, 1989). 
O aprimoramento da utilização de conduítes é um método que potencialmente poderia melhorar os resultados funcionais.

O resultado de inúmeros estudos sugere que os axônios em regeneração são capazes de se alinhar através da ação de fatores neurotrópicos e neurotróficos (weber et al, 1996; Lundborg et al, 1986; Mackinnon et al, 1986; Seckel et al, 1986; Brushart e Seiler, 1987).

Desta maneira, o crescimento do nervo dentro de um tubo, como um guia, teoricamente permite que esses fatores de crescimento atuem de forma mais concentrada, de modo a levar a um maior alinhamento entre os cotos proximais e distais, quando comparado com o que pode ser conseguido utilizando-se técnicas visuais (sutura borda a borda ou enxertia) para reparo de lesões neurais (Koeber et al, 1989).

A utilização de tubos condutores elimina a necessidade de enxertia de pequenos fragmentos de nervo (Dellon e Mackinnon, 1998). O nervo sural é o mais utilizado como doador para enxertia, no entanto, o seu uso não é feito sem que haja morbidade local. Staniforth e Fisher demonstraram em seu estudo que $44 \%$ de seus pacientes queixavam-se da perda de sensibilidade das porções laterais do pé e do tornozelo (Staniforth e Fisher, 1978), enquanto que $42 \%$ de seus pacientes reclamavam de parestesia na panturrilha e $16 \%$ de dor intensa nessa região.

Ortiguela reportou que em $6,1 \%$ de seus pacientes apresentaram sintomas relacionados com a presença de neuromas na perna doadora e que $9,1 \%$ dos pacientes não ficaram satisfeitos com a alteração da sensibilidade no pé (Ortiguela et al, 1987). 
Rappaport et al (1993) mostraram que 10\% dos pacientes que retiraram o nervo sural para enxertia de nervo, apresentaram infecção na área doadora, 12\% apresentaram cicatrização retardada, 5\% com dor cronificada nas áreas em que o nervo é responsável pela sensibilidade; segundo esses autores, a taxa de complicações foi de $27 \%$. Na literatura, observamos que outros autores reportaram em seus estudos, a incidência de dor considerável e parestesias que variaram entre 10 a 21\% (Dyck e Lofgren, 1968; Puburski et al, 1985; Perry e Bril, 1994).

O conceito de câmara de tubulização foi retomado e ganhou mais relevância há cerca de quinze anos atrás, a partir da demonstração de que um nervo é capaz de ser reconstituído através do crescimento a distâncias antes intransponíveis através de um tubo mesotelial (Keeley et al, 1993) e de um tubo de silicone, que quando interposto entre as extremidades da lesão, poderia ser usado para coletar fatores neurotróficos sintetizados em ambos os segmentos do nervo (Brunelli et al, 1993).

A câmara de tubulização demonstrou que pode ser uma ferramenta eficiente para o estudo dos fenômenos celulares e bioquímicos envolvidos na regeneração neural (Robinson et al, 1993; Swan , 1941).

O processo de regeneração através desses tubos inicia-se com a exsudação de um líquido acelular no interior da câmara, formando uma matriz sobre a qual as células de Schwann, fibroblastos e capilares crescem para criar um novo tronco com uma aparência semelhante ao normal. O grau de exsudação, de difusão de fatores de crescimento e nutrientes é limitado pela permeabilidade do material do qual o tubo é composto. 
É possível que os axônios sejam capazes de se alinhar em resposta a fatores neurotrópicos quando no interior de conduítes e crescerem para preencher o espaço entre o coto proximal e distal.

Estes fatos sugerem que a utilização de conduítes poderia melhorar os resultados quando comparamos à sutura direta ou à enxertia de nervo. A regeneração através de tubos condutores já foi demonstrada em vários tipos de modelos animais (Chiu DT, Janecka I, Krizek TJ, et al, 1982; Lundborg G, Gilberman RH, Longo RM, et al, 1982; Molander H, Olsson Y, Engkvist O et al, 1982; Colin W e Dnoff RB, 1984; Costa , 2006).

Estudos nessa linha têm envolvido materiais biológicos como tubos mesoteliais (Bignami et al, 1984; Brunelli et al, 1993), tubos amnióticos (Mohammad et al, 2000), vasos (veia, veia invertida, veia associada ao músculo - Ballance e Duel, 1932; Fawcet e Keynrs, 1986), ou materiais nãobiológicos de natureza não-reabsorvível (polytetrafluorethylene - Gore -tex Garrity, 1955; silicone - Ashur et al, 1987; Madison et al, 1988; Spector et al, 1991; Stensaas et al, 1989) ou reabsorvível (polyglactine - Fields, 1989; Molander et al, 1983; Seckel et al,1984; Costa, 1995; Costa, 2006) , já citados anteriormente.

Os tubos sintéticos, compostos de materiais absorvíveis, têm demonstrado melhores resultados funcionais tardios, quando comparados aos tubos de material não-absorvível (Madison, 1987; Nyilas et al, 1983).

Dellon e Mackinnon foram os primeiros a estudar a regeneração em macacos com a utilização de tubos absorvíveis de variados tamanhos (1990), comparando resultados eletrofisiológicos da utilização de enxertos e tubos de 
ácido poliglicólico (1988). Ambos os estudos demonstraram que a regeneração periférica do primata pode ser conseguida através da utilização de conduítes apropriados em defeitos de até $3 \mathrm{~cm}$.

Estudos recentes estabeleceram o tubo de ácido poliglicólico (tAPG), material artificial absorvível, como alternativa para enxertia de nervo ( Dellon e Mackinnon, 1988; Mackinnon e Dellon, 1990; Phan et al, 1991; Rosen et al, 1983; Costa, 1995; Costa, 2006).

Vários estudos desencorajam o uso de tubos não reabsorvíveis, porém, os estudos a respeito do uso de silicone continuam (Ashur et al, 1987; Madison et al,1988; Spector et al, 1991; Stensaas et al, 1989; Braga Silva,1999).

O tubo de silicone, utilizado em muitos estudos, tem como resultado da sua permanência e tubulização por longos períodos de tempo, uma compressão localizada, com conseqüente diminuição da regeneração axonal (Mackinnon et al, 1984; Mackinnon et al, 1985; Mackinnon e Dellon,1986).

A tubulização desperta grande interesse no âmbito experimental, devido ao fato de permitir a retirada de amostras de axônios em regeneração e possibilitar a introdução de fatores neurotróficos e outros adjuvantes em altas concentrações no sítio da lesão. Este fato é ilustrado através dos estudos de Chen e cols. (1989) e Rich e cols. (1989) que demonstraram uma taxa de regeneração aumentada em animais nos quais foram introduzidos NGF no interior da câmara de tubulização e Costa em1995 com a utilização de GM1.

Outra possibilidade de conduíte é a utilização de enxertos alogênicos preservados em glicerol. Cunha e Costa em 2007 compararam a regeneração neural obtida por interposição de auto-enxerto de nervo com tubulização de 
veia autógena e veia alógena conservadas em glicerol para regeneração neural em defeitos de $5 \mathrm{~mm}$ em ratos. Demonstraram não haver diferenças na recuperação funcional entre os grupos.

As características atribuídas aos conduítes permitem o desenvolvimento de um grande número de pesquisas nesta área, objetivando a obtenção de resultados melhores quando da lesão neural e a diminuição do número de seqüelas observadas. Para tal desenvolvimento é necessário a melhor compreensão da fisiopatologia da regeneração de nervos periféricos.

2 - Fisiopatologia da regeneração de nervos periféricos:

Quando um nervo periférico é lesado, surge localmente uma cascata de eventos responsáveis por uma tentativa de regeneração. Caracteriza-se pela remoção de tecido desvitalizado e pela criação de brotamentos e cones de crescimento axonais até a completa continuidade da unidade neural que propiciará novamente a condução de estímulos nervosos.

Dentre as formas de lesão de nervos periféricos a mais comum é por estiramento (Burnett, 2004). Isto ocorre porque apesar da elasticidade do nervo, atribuída ao colágeno endoneural, se ocorrer uma tração excessiva, esta ultrapassa a capacidade de estiramento do nervo e ocorre a lesão.

Lesões deste tipo podem ocorrer principalmente em casos de avulsões do plexo braquial, paralisia obstétrica e de forma associada a outras lesões em fraturas de extremidades. 
A laceração de nervos é tida como a segunda maior causa de lesões de nervos, como exemplo importante àquelas produzidas por facas, que respondem por aproximadamente 30\% das lesões graves (Jacques, 2000).

A compressão é o terceiro tipo de lesão mais comum e correlaciona-se localmente com compressão mecânica e com processo isquêmico. Ficou demonstrado em experimentos com torniquete que a isquemia é o fator causal principal do bloqueio de condução e que as fibras mielinizadas aparentemente são mais susceptíveis a efeitos isquêmicos que as não mielinizadas. (Lewis, 1931).

O grau de recuperação do reparo de um nervo periférico depende muito da extensão da lesão. A classificação do grau de lesão foi desenvolvida por Seddon e Sundeland e faz correlação entre as alterações microscópicas e a sintomatologia apresentada pelo paciente. (Seddon, 1943; Sundeland, 1950; Sundeland, 1978).

Seddon dividiu as lesões de nervos conforme a severidade em três categorias: Neuropraxia, axonotmesis e neurotmesis.

A neuropraxia é a forma mais branda, que não envolve perda de continuidade e causa somente perda funcional temporária. A sintomatologia é atribuída a um bloqueio de condução ionicamente induzido no local de lesão, entretanto, alterações sutis na estrutura da bainha de mielina também são encontradas.

A axonotmesis ocorre quando há uma completa transecção do axônio do nervo e da bainha de mielina circundante, enquanto que as estruturas mesenquimais como o perineuro e o epineuro continuam preservadas. A 
degeneração axonal e da mielina ocorrem distalmente ao ponto de lesão, causando a denervação completa.

A perspectiva de recuperação é muito boa em tais injurias porque o restante das estruturas mesenquimais não acometidas irão prover um meio propicio ao brotamento axonal para reinervar o órgão alvo.

A neurotmesis envolve uma descontinuidade da estrutura neural. A perda funcional é completa e a recuperação sem intervenção cirúrgica, usualmente não ocorre por causa da formação cicatricial local exuberante e pela perda de estruturas mesenquimais responsáveis por guiar os brotos axonais.

Sunderland (1978) introduziu modificações a esta classificação acrescentando à mesma mais duas categorias para caracterizar o grau de lesão local. O primeiro grau de lesão é equivalente à Neuropraxia e o segundo grau de lesão se equivale à axonotmesis. O terceiro grau de lesão neural ocorre quando há uma ruptura do axônio (axonotmesis) e também uma injúria parcial do endoneuro. Esta caracterização seria intermediaria à axonotmesis e à neurotmesis de Seddon. Dependendo da extensão da lesão endoneural, a recuperação funcional pode ser possível. 


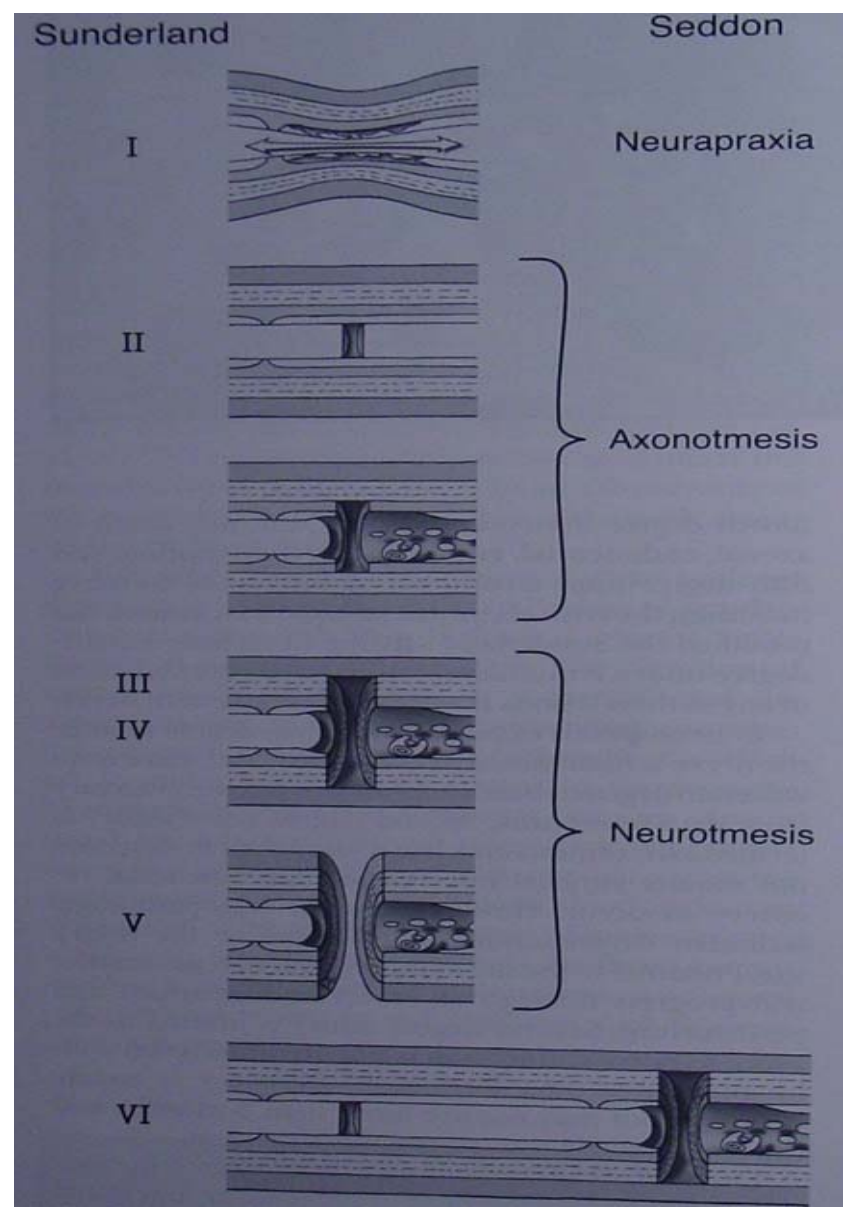

Figura 1. Classificação de lesões de nervos periféricos segundo Sunderland. ( McCarthy JG; Plastic Surgery. Philadelphia :W. B. Saunders; 1990. v.1,p. 656) .

Sunderland dividiu a neurotmesis da classificação de Seddon no que corresponde ao quarto e quinto graus de lesão. No quarto grau de lesão de 
Sunderland, todas as porções do nervo estão rompidas exceto o epineuro. A recuperação não é possível sem intervenção cirúrgica. De forma similar, o quinto grau de lesão envolve o dano completo do nervo.

Antes de ocorrer a regeneração das fibras, uma serie de processos degenerativos ocorrem localmente, muitos dos quais são importantes para o inicio do processo de regeneração. O sucesso da regeneração é intrinsecamente dependente da severidade da lesão e do processo degenerativo resultante.

As alterações fisiopatológicas são mínimas ou não ocorrem no primeiro grau de lesão (Seddon-Sunderland) enquanto que ocorre o bloqueio de condução temporário sem que ocorram processos degenerativos ou regenerativos locais.

No segundo grau de lesão (axonotmesis) há uma pequena alteração histológica no sitio de lesão ou proximal a este sitio. Entretanto, distalmente ao sitio de lesão, ocorre um processo degenerativo cálcio dependente conhecido como degeneração Walleriana ou degeneração anterógrada (Waller, 1850).

Na degeneração Walleriana, a mudança histológica característica é a fragmentação do axônio e da bainha de mielina, um processo que se inicia em poucas horas após a lesão.

$\mathrm{Na}$ ultramicroscopia evidenciou-se um desarranjo de neurotubos e de neurofilamentos, com edema e deformação do axônio. Por aproximadamente 48 a 96 horas após a lesão, há perda da continuidade axonal. 
A desintegração da bainha é lenta no principio, mas se torna mais rápida em aproximadamente 36 a 48 h. As células de Schwann desempenham um papel fundamental na degeneração Walleriana. Elas tornam-se ativas dentro das primeiras 24 horas após a lesão, exibindo à microscopia, um crescimento nuclear e citoplasmático bem como um aumento importante do índice mitótico. Estas células se dividem rapidamente para formar células diferenciadas e adaptadas para conduzir o processo de degeneração e de reparo.

A célula de Schwann ainda não diferenciada desempenha o papel de remover os axônios e a mielina em degeneração.

Os macrófagos migram para o sitio de lesão através dos vasos sanguíneos da região, que se tornam permeáveis neste momento. Em conjunto com as células de Schwann iniciam a fagocitose e limpeza do sitio de lesão em um processo que requere algo entre uma semana a vários meses.

As células satélite endoneurais também desempenham um papel primordial neste processo, principalmente dentro das duas primeiras semanas de lesão neural. Elas liberam histamina e serotonina que geram o aumento da permeabilidade capilar e facilitam a migração de macrófago.

Durante as fases iniciais, os tubos endoneurais se edemaciam em resposta ao trauma, mas depois das primeiras duas semanas há uma regressão parcial do processo e conseqüentemente do diâmetro destes tubos. Leva aproximadamente cinco a oito semanas para que o processo degenerativo se complete e surjam fibras nervosas com células de Schwann dentro de uma envoltura delgada de endoneuro. 
Em lesões de terceiro grau acontece uma reação induzida pelo trauma bem maior. Ocorrem lesões intrafasciculares que levam a retração da fibra nervosa distal seccionada devido à elasticidade do endoneuro. Um trauma vascular local leva a hemorragia e edema que resultam em uma resposta inflamatória vigorosa. Fibroblastos proliferam-se e uma cicatriz fibrosa densa causa um edema fusiforme do segmento acometido.

Um tecido cicatricial interfascicular também se desenvolve de forma que todo o tronco do nervo é acometido e aumenta em diâmetro permanentemente. Pode se apresentar, com freqüência, aderida ao tecido cicatricial perineural.

O Segmento Distal

Distalmente ao segmento acometido, a degeneração Walleriana segue uma seqüência bem semelhante à observada em lesões de segundo grau.

Uma diferença importante é que a lesão intrafascicular prejudica a regeneração axonal e, então, os tubos endoneurais permanecem denervados por longo período. Enquanto permanecem denervados, os tubos endoneurais começam a se retrair em um processo que alcança seu máximo três a quatro meses após a lesão. (Sunderland, 1950; Sunderland 1978; Sunderland, 1990).

O envoltório do endoneuro se espessa progressivamente em conseqüência do acúmulo de colágeno ao longo da superfície externa da membrana das células de Schwann. Se o tubo endoneural não receber um axônio em regeneração, ocorrerá uma fibrose progressiva local, levando à obliteração do mesmo. 
Acúmulos de células de Schwann representando tubos endoneurais colapsados se tornam microscopicamente visíveis tardiamente no desenvolvimento da degeneração Walleriana nas lesões mais significantes.

As colunas de Células de Schwann são conhecidas como as bandas de Büngner e se tornam guias importantes para brotamentos axonais durante a reinervação. Estas bandas demonstram precocemente um segundo papel para as células de Schwann depois da lesão do nervo, o de suporte para o brotamento de axônios.

Em lesões de quarto e quinto graus, a reação local ao trauma é intensa. Tubos endoneurais e também fascículos são rompidos, células de Schwann e axônios perdem o envoltório. O epineuro também está danificado e um estado reativo local caracterizado pela presença de fibroblastos epineurais estará presente dentro das primeiras vinte e quatro horas da lesão. Junto a esta reação, verifica-se a presença de proliferação de células de Schwann e de fibroblastos peri e endoneurais.

Picos vigorosos de proliferação celular ocorrem dentro da $1^{\text {a }}$ semana e continuam por um longo período. Como ocorre nas lesões de graus menores, o aumento de permeabilidade capilar, provavelmente como resultado de degranulação de mastócitos, edema e infiltração de macrófagos surge em seguida. A magnitude desta resposta se correlaciona com a severidade do trauma ao nervo e aos tecidos circunvizinhos.

Em lesões de quarto e quinto graus, os cotos distais dos nervos lesados se tornam uma massa edemaciada com acumulo de células de Schwann desorganizadas, vasos capilares, fibroblastos, macrófagos e fibras colágenas. 
Axônios em regeneração que alcançam este bulbo edemaciado encontram dificuldades o para crescimento.

Muitos axônios que formam espirais dentro do tecido cicatricial retrocedem ao longo do segmento proximal ou se estabelecem no tecido circunvizinho. Alguns podem alcançar o coto distal dependendo de múltiplos fatores: a severidade do dano original, a extensão da formação de cicatriz e o tempo gasto pelos axônios para chegar ao local da lesão.

Como em lesões de terceiro grau, a descontinuidade do endoneuro por períodos prolongados leva ao encolhimento progressivo e fibrose, podendo ficar obliterado completamente por fibras de colágeno.

Segmento Proximal e Corpo celular

Mudanças em corpos celulares de neurônios e em fibras proximais de nervos ocorrem conforme a severidade da lesão e também depende da proximidade do segmento acometido com o corpo celular.

Células de Schwann degeneram-se inevitavelmente ao longo do segmento proximal perto da área da lesão. Esta degeneração proximal pode ser mínima (próximo ao nodo de Ranvier) ou pode se estender por todo o segmento proximal até o nível do corpo celular. Se o corpo celular se degenera, o que pode acontecer em um trauma severo, o segmento proximal inteiro sofrerá degeneração de Walleriana e é fagocitado. 
Lesões significativas da fibra nervosa no segmento axonal proximal terá reduções no seu diâmetro, particularmente se não forem restabelecidas as conexões funcionais para os órgãos alvo. A velocidade de condução do nervo estará indiscutivelmente reduzida.

Como conseqüências da regeneração, os diâmetros axonais aumentarão, mas nunca vão alcançar níveis semelhantes aos que possuíam antes da lesão.

Existe interdependência entre o corpo celular e o axônio em termos de recuperação: o corpo celular não se recupera completamente sem o restabelecimento de conexões periféricas funcionais e o calibre dos axônios dependerá em grande parte da recuperação do corpo celular.

O próprio corpo celular do nervo reage a uma lesão axonal de um modo previsível. Dentro das primeiras 6 horas da lesão, o núcleo migra para a periferia da célula, os grânulos de Nissl e o reticulo endoplasmático rugoso se separam e se dispersam ao longo do citoplasma. Este processo é chamado cromatólise.

Simultaneamente, há uma resposta proliferativa abundante de células gliais do perineuro, provavelmente estimulada pelo processo de cromatólise. Os processos de células gliais se alongam até o neurônio afetado e interrompem as conexões sinápticas, possivelmente para isolar o neurônio até a sua recuperação.

A sobrevivência de uma célula nervosa não está assegurada após uma lesão severa. A incidência de morte celular de neurônios de gânglios da raiz dorsal com lesões do tipo axonotmesis varia entre 20 e 50\% (Lundborg, 2000). 
A morte celular freqüentemente ocorre mais se a axonotmesis ocorrer a nível proximal e em lesões que envolvam nervos sensoriais ou nervos cranianos. Este processo de morte celular neuronal induzida pela lesão axonal permanece mal compreendido, mas é creditado a condições dentro do microambiente do local de lesão.

$\mathrm{Na}$ realidade, a capacidade regenerativa do microambiente do nervo periférico foi relatada desde o começo do século XX quando Cajal propôs que era o microambiente do nervo periférico e não fatores intrínsecos que explicariam o fracasso da regeneração.

Vários estudiosos em sistemas moleculares continuam investigando sobre o papel estimulador das células de Schwann e demonstraram a presença de moléculas neurotróficas no microambiente do nervo periférico que parecem influenciar na sobrevivência do neurônio após lesões (Varon et al, 1978; Yan et al , 1992; Yin et al , 1998).

Regeneração de nervos

A regeneração de um nervo com lesão severa só começará depois que a degeneração Walleriana estiver em curso, mas em lesões moderadas, os processos regenerativos e de reparo locais começam quase que imediatamente. Para lesões de primeiro e segundo graus (Neuropraxia e axonotmesis), a restauração da função é o caminho comum. Isto acontece precocemente por reversão do bloco de condução ou mais tardiamente por 
regeneração axonal. A recuperação funcional poderá ser completa nestes graus mais moderados de lesão.

Em lesões nervosas mais severas na qual o endoneuro é rompido, os axônios em regeneração não se mantêm confinados nos envoltórios neurais. Eles podem vagar por tecidos circunvizinhos ou se tubulizar em endoneuros impróprios, possibilitando a falha na reinervação de seu órgão alvo original. A recuperação neurológica estará mais comprometida proporcionalmente ao grau de severidade da lesão.

A sucessão de graus de regeneração pode ser dividida em zonas anatômicas: 1) o corpo celular do neurônio; 2) o segmento entre o corpo celular e o local da lesão; 3) o próprio local de lesão; 4) o segmento distal entre o local de lesão e o órgão alvo; e 5) o próprio órgão alvo. Um atraso na regeneração ou uma regeneração mal sucedida podem ser atribuídos a mudanças patológicas que impedem os processos reparadores normais a uma ou mais destas zonas.

A regeneração e a fase de reparo seguinte à lesão do nervo podem durar muitos meses. Os sinais mais precoces desta fase são mudanças visíveis no corpo celular. O núcleo retorna ao centro da célula e proteínas nucleares reorganizam-se nos grânulos de Nissl.

Após a lesão, muitas funções metabólicas foram alteradas durante a cromatólise. A síntese de RNA foi aumentada e a síntese de neurotransmissores diminuiu. A cromatólise indica uma alteração fundamental da função celular passando de transmissão sináptica para reparo celular. 
A máquina metabólica foi reprogramada de forma que a célula poderia produzir uma vasta quantidade de proteínas e lipídios necessários para o crescimento axonal durante a fase de regeneração.

Uma complexa e mal elucidada interação ocorre entre o corpo celular e o brotamento axonal. O axoplasma que serve para regenerar o brotamento axonal surge entre segmento axonal proximal e o corpo celular. Transportadores rápidos e lentos do axoplasma vão carrear substâncias do corpo celular para o local da regeneração axonal.

A taxa de aumento de síntese protéica e de síntese de lipídios no corpo celular do neurônio influencia na taxa de avanço e no calibre final do axônio regenerado. A capacidade do neurônio periférico humano para iniciar uma resposta regenerativa parece persistir durante pelo menos 12 meses depois da lesão e uma franca resposta ainda pode ser esperadas até mesmo depois de repetidos traumatismos locais.

O comprimento do segmento entre o brotamento axonal e o local da lesão depende da severidade da lesão original e da degradação retrógrada conseqüente.

Podem ser vistos os primeiros sinais de crescimento axonal neste segmento já nas primeiras 24 horas após a lesão ou estes sinais podem só aparecer após semanas em lesões mais severas.

A taxa de crescimento axonal é determinada pela atividade do cone de crescimento especializado na extremidade de cada broto axonal e pela resistência oferecida pelo tecido lesado que fica entre o corpo celular e o órgão alvo. 
Pode haver vários brotamentos axonais dentro de cada bainha de endoneuro, até mesmo em lesões mais moderadas, isso não significa necessariamente a destruição do endoneuro. A ocorrência de processos degenerativos e regenerativos é tal que pode haver sobreposição entre estes em alguns segmentos em dado momento.

Em lesões mais moderadas nas quais não há um atraso na regeneração ao longo do sitio de lesão, os cones de crescimento na porção distal do axônio podem encontrar uma área com a presença de debris da degeneração Walleriana no segmento distal. Estes debris podem não impedir que a regeneração ocorra. Isso se deve ao fato de que o cone de crescimento segrega uma protease que pode ajudar dissolver o material que está bloqueando o seu caminho. (Krystosek et al, 1981).

Em lesões nervosas muito proximais nas quais há um considerável demora até que o axônio alcance o segmento distal, o endoneuro distal ainda vazio acaba por diminuir o seu diâmetro. Este fator pode ser responsável, em parte, por reduzir a velocidade de crescimento do axônio na porção terminal do nervo.

Uma Intervenção cirúrgica que interrompa o aporte por artérias nutrientes circunvizinhas não parece prejudicar a regeneração axonal, contanto que não sejam rompidas aquelas artérias longitudinais que se encontram dentro do próprio nervo.

Em lesões nervosas severas onde há o rompimento do endoneuro, fascículos ou troncos formam-se obstáculos quase intransponíveis para os axônios em regeneração alcançarem o sitio da lesão. 
Se há uma grande falha entre os cotos do nervo roto, permitindo que os brotamentos axonais cresçam sem qualquer orientação, estes podem atingir tecidos circunvizinhos ao invés de seu órgão alvo.

A Cicatrização está inevitavelmente presente no local de lesão severa; a extensão desta depende de fatores múltiplos que incluem o tempo gasto para a chegada dos brotos axonais ao órgão alvo após o dano.

Foi bem documentado que axônios em regeneração podem atravessar com sucesso longas distâncias, apesar da presença de tecido cicatricial significativo no local, porém não há garantias de que eles seguirão a orientação original do fascículo. Eles podem crescer em um endoneuro funcionalmente impróprio ou até mesmo não alcançar um endoneuro. Qualquer que seja a circunstância resultará em axônios perdidos e falhos na reinervação.

Axônios previamente não mielinizados podem se regenerar dentro de uma bainha do endoneuro que antigamente continha axônios mielinizados e vice-versa. Esta regeneração não será exuberante. A resistência de um axônio encontrar o sitio de lesão resulta na formação de brotos axonais pequenos e múltiplos. Estes brotos axonais não alcançarão o segmento distal.

Nenhum neurotropismo específico conhecido é capaz de aumentar o crescimento de um axônio em regeneração no seu endoneuro original, mas alguma forma de influência neurotrópica foi demonstrada em estudos experimentais.

A cicatriz dentro do sitio de lesão impede a regeneração e desencaminha os brotos axonais rumo ao endoneuro, impedindo o retorno 
funcional. O tecido cicatricial residual também interfere com o processo de maturação de axônios que ocorrem no sitio de lesão.

Axônios que alcançam com sucesso o endoneuro do segmento distal têm uma boa chance de alcançar o órgão alvo. A taxa de regeneração distal será mais lenta se os tubos do endoneuro forem rompidos.

O cone de crescimento especializado que fica na extremidade de cada broto axonal contém múltiplas estruturas chamadas filopódios que aderem à lâmina basal da célula de Schwann e a usam como um guia. Foi demonstrada a existência de fatores quimiotáticos como sendo importantes para dirigir o avanço dos cones de crescimento (Gundersen et al, 1980; Dodd et al , 1988).

Pelo fato de que muitas vezes vários brotos axonais pequenos poderem entrar no mesmo tubo endoneural é que se pode vislumbrar uma fibra nervosa regenerada poder conter mais axônios que o nervo de origem.

Se um órgão alvo funcionalmente não é alcançado, não haverá o desenvolvimento do axônio e da remielinização. De forma semelhante, o desenvolvimento e a maturação axonais serão abortados se o órgão alvo sofrer mudanças degenerativas, devido à denervação prolongada, não permitindo assim o estabelecimento de conexões funcionais.

Se a entrada de axônios em regeneração no segmento de distal se atrasar mais que quatro meses, os axônios estarão entrando em tubos de endoneuro com diâmetro menor, geralmente três $\mathrm{m} \mu$ ou menos. Esse estreitamento pode tornar mais complicado para os brotos axonais localizarem e se canalizarem nos tubos de endoneuro, mas isto não parece impedir o 
crescimento de axônios uma vez que os brotos já estejam dentro dos tubos. Isso é devido provavelmente às propriedades elásticas do endoneuro.

O retorno de função não requer uma recuperação absolutamente fiel da arquitetura de nervo. Os efeitos da denervação prolongada prejudicam a recuperação funcional devido ao impedimento do crescimento dos axônios em regeneração de entrar nos tubos de endoneuro apropriados e alcançarem o seu órgão alvo.

Os órgãos alvo sofrem alterações histológicas características com a degeneração do nervo e com a sua subseqüente reinervação. Fibras musculares se atrofiam rapidamente (uma redução média de $70 \%$ de seu diâmetro secional em dois meses) e os núcleos celulares assumem uma posição central em lugar da posição periférica normal.

As regiões sinápticas das placas motoras ficam preservadas durante pelo menos um ano após a denervação.

Uma imensa proliferação de fibroblastos também caracteriza o quadro histológico da denervação. O colágeno novo se deposita no endo e perimisio.

Em geral, fibras musculares não são substituídas por tecido conjuntivo, mas muitas se atrofiam e são isoladas por tecido conjuntivo denso, de forma que o padrão interno global da arquitetura do músculo é preservado.

A reabsorção parcial de fibras musculares ocasionalmente acontece. Este é um fenômeno geralmente observado entre seis e 12 meses depois da denervação. 
Brotos axonais seguem as células de Schwann originais até as placas motoras denervadas para refazer as junções neuromusculares (Seckel, 1990). O crescimento colateral do axônio também acontece, resultando em grupos de fibras musculares reinervadas, rápidas ou lentas. Este é um achado característico em músculo reinervado, contrastando nitidamente com o padrão randômico observado em um músculo normal.

Infelizmente, a recuperação motora pode ser incompleta e geralmente acontece depois de lesões nervosas moderadas e severas. Isto é devido a vários fatores dentro do próprio músculo e no nervo em regeneração.

A fibrose intramuscular pode limitar a eficácia da contração produzida por um impulso nervoso. Uma fisioterapia apropriada poderia ajudar a manter os músculos denervados em uma ótima condição para receber uma reinervação pelos axônios em regeneração.

A recuperação funcional motora é prejudicada obviamente se um número significativo de axonios não refizer conexões funcionais bem sucedidas com o músculo. Até mesmo se o numerário de axônios é adequado, pode ocorrer reinervação cruzada produzindo um resultado funcional pobre: um músculo originalmente "rápido" pode ser reinervado por axônios de fibras musculares "lentas" e o resultado pode ser uma forma mista com uma contração ineficiente.

Naqueles casos os quais a recuperação motora acontece de forma qualitativa, o resultado funcional pode ser prejudicado por déficits sensoriais concomitantes, particularmente a propriocepção. Receptores sensoriais denervados sobrevivem e podem se recuperar funcionalmente por vários anos. 
Em lesões de primeiro e de segundo graus, o retorno sensorial estará completo em seu padrão original até mesmo depois de 6 a 12 meses de denervação. Isto está devido à reinervação fiel dos receptores sensoriais pelos axônios originais dos mesmos.

Após lesões mais severas com a regeneração do nervo, a recuperação sensorial nunca estará completa. Isto está relacionado ao fracasso dos axônios sensoriais para alcançar a pele, reinervação cruzada e possivelmente degeneração de receptores sensoriais.

A reinervação sensorial parece ser uma modalidade a parte de reinervação, onde a ocorrência de reinervação cruzada pode acontecer com maior freqüência.

Alguma controvérsia existe acerca do encapsulamento de receptores sensoriais denervados. Estes receptores incluem corpúsculos de Pacini e corpúsculos de Meissner que são receptores que captam o toque leve e a vibração e as células de Merkel, receptores que captam o toque contínuo e a pressão lenta.

É creditado a estes receptores especializados o potencial de sobreviverem em um estado de atrofia por longos períodos, como que esperando a chegada de um coto neural regenerado próprio.

O período de sobrevivência não foi claramente estabelecido, porém, há alguma evidência que indica que esta sensação protetora se recuperaria anos depois da denervação, sendo captada através de receptores sensoriais menos elaborados. 
A taxa de regeneração axonal geralmente é constante e, em situações clínicas, é de um mm por dia, seguido freqüentemente por um sinal de Tinel. Porém, foram reportadas taxas de regeneração variando entre 0.5 a $9 \mathrm{~mm}$ por dia. Esta variabilidade é atribuída a vários fatores: 1) a taxa de crescimento do axônio diminui com o aumento da distância do corpo celular para a extremidade do axônio em regeneração. 2) as medidas da regeneração axonal foram realizadas em várias espécies de animais e com diferentes métodos de lesão de nervos. 3) as técnicas de avaliação da regeneração axonal foram diferentes (por exemplo, através do sinal de Tinel comparado com recuperação funcional). Além disso, a taxa de regeneração pode depender da natureza e severidade da lesão do nervo, a duração da denervação e a condição dos tecidos periféricos.

A regeneração após um reparo cirúrgico de um nervo é mais lenta que uma regeneração de um nervo parcialmente acometido. Isto reflete que quanto mais camadas acometidas (epineuro, perineuro e endoneuro) maior a dificuldade na recuperação da função. A idade avançada também foi demonstrada como fator de retardo da taxa de crescimento de axonal.

A regeneração axonal não é sinônima de retorno de função. Um processo de maturação precede a recuperação funcional. Alterações morfológicas de maturação ocorrem por todo o axônio em regeneração a uma taxa mais baixa que aquela do crescimento do axônio e se continua por um período de até aproximadamente um ano. 
A remielinização se desenvolve de forma semelhante para fibras nervosas em crescimento, desenvolvendo o alinhamento de células de Schwann e recobrindo o axônio para formar uma envoltura multilamelar.

Este processo começa dentro das duas primeiras semanas do inicio da regeneração axonal e resulta em axônios mielinizados bastante semelhantes aos originais exceto pela presença de espaços internodais encurtados.

O diâmetro do axônio aumenta progressivamente até que alcance dimensões normais, mas esta amplificação é dependente do estabelecimento de conexões funcionais entre a porção terminal do axônio e o órgão alvo apropriado.

Para que os processos de degeneração e regeneração aconteçam de um modo ordenado é necessário um sistema sofisticado de comunicação celular. Investigadores suspeitaram da existência de uma cascata de moléculas e fatores tróficos semelhantes em complexidade ao que é visto em uma cascata da resposta inflamatória.

Os fatores neurotróficos como NGF (Fator de crescimento do nervo), fator neurotrófico derivado de células cerebrais, fator neurotrófico ciliar, e muitos outros foram identificados e foram relacionados ao processo de reparo de nervos (Barbin et al, 1984; Seckel , 1990; Yan et al, 1992; Yin et al,1998).

O fator de crescimento de nervo (NGF) foi a primeira molécula neurotrófica a ser identificada e permanece como a mais caracterizada (LeviMontalcini et al , 1951). Está relacionado à sobrevivência da célula nervosa e na manutenção do seu estado normal e parece ser um componente importante do processo de reparação do nervo. 
São libertados fatores como NGF tonicamente do nervo periférico a órgãos alvo e transferido ao corpo celular do nervo por transporte axonal retrógrado (Slack et al, 1983). É possível que a diminuição do NGF e de outros fatores tróficos que normalmente alcançariam o corpo celular, seriam o sinal molecular que deflagre o processo de reparação neural como resultado do rompimento axonal que acontece imediatamente após a lesão do nervo.

Em um experimento com NGF, foi aplicado a neurônios com axonotomia e foi percebida a inversão das mudanças do corpo celular vistas na cromatólise (Otto et al, 1987). Em seguida à lesão, as concentrações de NGF e NGF do RNA mensageiro estavam aumentadas, padrão consistente de substâncias neurotróficas. Acredita-se que macrófagos invasores ao sitio de lesão estimulam a produção de NGF por meio da interleucina-1 beta, o que sugere que o macrófago está envolvido com fagocitose e regeneração. De forma semelhante, foi demonstrado que as células de Schwann podem produzir fatores neurotróficos, inclusive NGF, no sitio de lesão.

Os fatores neurotróficos, bem como outras moléculas sinalizadoras para as células nervosas, se ligam aos receptores de kinase de tirosina específicos que transmitem um sinal que regula a ativação de genes. Receptores para o NGF em grande número nas células de Schwann formam as bandas de Büngner depois da lesão. O NGF que se liga a estes receptores nas células de Schwann é apresentado aos brotos axonais. Este aporte de NGF pelo axônio é transferido retrogradamente do cone de crescimento para o corpo celular, provendo um estímulo contínuo para o crescimento bem como um guia para o axônio em crescimento (Taniuchi et al, 1988). 
A resposta do nervo periférico à lesão é algo unico. Neurônios do sistema nervoso central não apresentam a mesma habilidade para regenerarem as conexões perdidas. Em lugar de reconstruir, neurônios do sistema nervoso central evitam a lesão se fortalecendo e reprogramando caminhos incólumes de forma que eles substituam as funções que foram perdidas.

Os processos complicados da degeneração e regeneração dos nervos periféricos só são entendidos em parte. No futuro, as investigações nesta área renderão informações que possam conduzir a avanços cirúrgicos e terapêuticos para o tratamento de lesões de nervos periféricos no sentido de estimular o crescimento axonal de forma eficiente e especifica para o seu órgão alvo com o retorno qualitativo da função. Uma das tentativas para tal é a utilização de aloenxerto de nervo preservados em glicerol.

Preservação de tecidos em glicerol:

O glicerol (1,2,3 propanotriol), também conhecido como glicerina, é um álcool triídico de fórmula molecular $\mathrm{C} 3 \mathrm{H} 8 \mathrm{O} 3$, liquido semiviscoso, incolor, transparente, de leve odor, sabor adocicado, com peso molecular de 92,09. É miscível em água e álcool, sendo insolúvel em clorofórmio, éter, óleos fixos e voláteis. Sua densidade a $25{ }^{\circ} \mathrm{C}$ é de $1,249 \mathrm{~g} / \mathrm{cm} 3$, com índice de refração a $20^{\circ} \mathrm{C}$ entre 1,4696 e 1,4726 (Pigossi, 1967). 
O glicerol foi utilizado inicialmente na preservação de peças anatômicas, tendo sido Laskowski, em 1885, o pioneiro no uso deste álcool. Laskowski recebeu na época o prêmio da Academia de Ciências de Caen por tal procedimento.

Outros autores adotaram este método, porém foi com Giacomini (1878) que este se tornou mais divulgado, pois fez uso do glicerol para conservação de peças anatômicas do sistema nervoso (medula e encéfalo), bem como para uso complementar em refrigeração de cadáveres.

O glicerol é capaz de desidratar o tecido, removendo a maior parte da água intracelular, sem, contudo, alterar a concentração iônica das células, sendo um eficiente fixador e protetor da matriz tecidual, pois inviabiliza as células locais mantendo a arquitetura local.

A ausência de reações inflamatórias agudas dos implantes preservados em glicerol indica a baixa antigenicidade desse meio de conservação (Richters, 1996).

O glicerol é ainda um dos bons meios de conservação de tecidos por suas propriedades antibactericina e antiviral, inclusive sendo eficaz para a eliminação do vírus HIV (Marshall, 1995). Diminui severamente a antigenicidade, é de fácil manuseio e baixo custo, sendo por estas razões o método de escolha utilizado em várias instituições européias e outras partes do mundo (Herson et al, 2002; Ferreira et al, 2000).

O glicerol a 20\% foi aplicado na conservação de derme autóloga usada como implante não causando infecção, conforme estudo realizado por Crawford et al (1957). Também foi utilizada à temperatura ambiente na 
preservação de escleras (Sabates, 1967). O autor submeteu tratamento a 34 implantes, sendo que desses, 28 não apresentaram rejeição. Tornou-se na década de 60 o método preconizado para conservação de escleras pelos bons resultados obtidos.

Em nosso meio, Pigossi em 1967, introduziu a conservação de tecidos com o uso de glicerol, a partir de experimentos com Dura-máter homóloga, armazenada à temperatura ambiente como substituto dural. Este autor relatou neoformação nos implantes, ausência de contaminação, ausência de formação de granulomas de corpo estranho e ausência de resposta imune local, sendo a dura-máter material apropriado para implantes durais, mantendo inclusive características como resistência à tração e conservação de textura. Estudos subseqüentes avaliaram a manutenção de várias propriedades imunológicas da dura-máter conservada em glicerol à temperatura ambiente (Fiolova, 1976).

Apesar de seu potencial uso para conservação de diversos tipos de tecidos e a versatilidade no preparo e manejo, a aplicação mais freqüente do glicerol é na conservação de pele homógena cadavérica. Feito por meio de bancos de pele e tecidos serve para o uso como enxertos temporários no tratamento de queimaduras (Ghosh, 1997).

A técnica de preservação de pele de cadáver em glicerol foi aplicada inicialmente com sucesso por Hoekstra e cols. no começo dos anos 80, impulsionados pela insatisfação com o manejo e resultados obtidos até então com a criopreservação de pele de cadáver.

Os homoenxertos de pele de doador cadáver foram usados clinicamente no Red Cross Hospital em Beverwijk (Holanda) em 1983. Seguidos relatos 
provenientes deste centro, encorajaram e levaram a uma gradual aceitação e popularidade desta metodologia em toda a Europa. De fronte a uma grande demanda insurgente, o banco de tecidos, apoiado financeiramente pelo Dutch Burns Fundation, se reorganizou e solidificou-se através da fundação do Euro Skin Bank (ESB) em 1992.

A preservação de homoenxertos em glicerol é tecnicamente simples e requer poucos meios e equipamentos para sua funcionalidade. Esse método de preservação é efetivo como agente bactericida e antiviral, é intrinsecamente seguro e estocável em um refrigerador doméstico por um longo tempo.

Quanto à utilização para preservação de vasos sanguíneos, Farhner (2004) conduziu um trabalho experimental em ratos wistar, avaliando a concentração do glicerol e período de incubação na preservação de artérias aórticas de ratos, utilizando uma série em baixas concentrações (30, 50, 75\%) e uma série em altas concentrações (70, 85 e 98 \%). Comparou com casos controle para investigar as alterações morfológicas e funcionais na parede desses vasos.

Esse estudo demonstrou que as características biomecânicas da aorta do rato, como resistência, e a estrutura da matriz extracelular encontravam-se preservadas em suas características apesar das duas formas distintas de preservação, não havendo diferenças nas características histológicas entre as mesmas. Não foi encontrado nenhum tipo celular local, o que é uma vantagem, já que provavelmente as células endoteliais seriam as responsáveis pelo componente imunogênico do transplante arterial. 
Isso torna a conservação de tecido vascular com glicerol um método vantajoso em relação a outros métodos de preservação, justamente pela baixa imunidade dos tecidos tratados e pela conservação de suas propriedades mecânicas, conservando um arcabouço estrutural viável para a realização de enxertos venosos. (Costa, 1995; Costa et al, 2006; Cunha e Costa, 2007). 


\section{MATERIAIS E METODOS}

Quinze ratos machos da raça Wistar, com peso variando entre 200 e $300 \mathrm{~g}$, e idade ao redor de oito semanas foram divididos em três grupos de cinco animais. Com técnica microcirúrgica criou-se um defeito de cinco mm no nervo fibular da pata traseira direita dos animais. Os ratos, então, foram subdivididos em três grupos distintos, de acordo com o método de reparação:

Grupo A: grupo controle; interposição imediata de auto-enxerto de nervo fibular.

Grupo B: grupo com tratamento através de tubulização com veia autógena conservada em glicerol.

Grupo C: grupo com tratamento através de interposição de nervo alógeno (proveniente de ratos Sprague-Dawney com peso, sexo e idade semelhantes ao rato Wistar) entre os cotos do nervo fibular.

No grupo A (grupo controle), o defeito do nervo periférico foi corrigido pelo reposicionamento de fragmento de nervo autógeno retirado e ressutura na orientação original com mononylon 10.0.

No grupo $B$, inicialmente retiramos um segmento de $1 \mathrm{~cm}$ de veia jugular interna, para ser conservada em glicerol a 98\% por sete dias consecutivos e refrigerado a $4{ }^{\circ} \mathrm{C}$. Após sete dias, criou-se um intervalo de $5 \mathrm{~mm}$ no nervo fibular e utilizou-se 0 segmento de $1 \mathrm{~cm}$ de veia jugular interna direita autógena preservado em glicerol como condutor da regeneração axonal ( Cunha e Costa , 2007). 
Nos animais do grupo C, os defeitos foram corrigidos através de enxertos de nervo alógeno extraídos de ratos da raça Sprague-Dawney e preservados em glicerol a $98 \%$ por sete dias consecutivos e sob refrigeração a $4^{\circ} \mathrm{C}$.

Os animais foram submetidos à avaliação funcional e em seguida, sacrificados seis semanas após a cirurgia de correção do nervo fibular para realização dos estudos histológicos. A avaliação da recuperação funcional foi feita por meio da técnica de análise dos padrões das pegadas impressas pelas patas posteriores dos ratos ("walking track analysis") nos períodos préoperatórios, pós-operatório imediato, na terceira semana de pós-operatório e no momento do sacrifício (seis semanas) (Tabela I). 


\begin{tabular}{|c|c|c|c|c|}
\hline GRUPO & DEFEITO & TRATAMENTO & $\begin{array}{l}\text { MOMENTO } \\
\text { DO } \\
\text { SACRIFÍCIO }\end{array}$ & NERVO \\
\hline $\begin{array}{l}\text { A } \\
n=6 \\
\text { (Rato } \\
\text { Wistar) }\end{array}$ & $5 \mathrm{~mm}$ & \begin{tabular}{|l} 
Auto-enxerto \\
(controle) (Rato \\
Wistar)
\end{tabular} & 6 semanas & Fibular \\
\hline $\begin{array}{l}\text { 1. B } \\
\mathrm{n}=6 \\
\text { (Rato } \\
\text { Wistar) }\end{array}$ & $5 \mathrm{~mm}$ & $\begin{array}{l}\text { 2. Veia } \\
\text { autógena } \\
(10 \quad \mathrm{~mm})(\text { Rato } \\
\text { Wistar) }\end{array}$ & 6 semanas & Fibular \\
\hline $\begin{array}{l}\mathrm{C} \\
\mathrm{n}=6 \\
\text { (Rato } \\
\text { Wistar) }\end{array}$ & $5 \mathrm{~mm}$ & $\begin{array}{|ll|}\text { 3. } & \begin{array}{l}\text { Nervo } \\
\text { Alógeno }\end{array} \\
& \\
(10 & \text { mm }) \quad \text { (Rato } \\
\text { Sprague-Dawley) }\end{array}$ & 6 semanas & Fibular \\
\hline
\end{tabular}

Tabela 1: Grupos experimentais com a distribuição dos animais de acordo com o tratamento.

\section{Procedimento Cirúrgico}

Em todos os procedimentos cirúrgicos os animais foram anestesiados utilizando-se pentobarbital sódico, na dose de $5 \mathrm{mg} / \mathrm{Kg}$ por via intraperitonial.

No grupo A (grupo controle), o acesso ao nervo ciático foi feito através de uma incisão na face posterior da pata traseira direita, com diérese cuidadosa sob a musculatura ventral para se obter a exposição do nervo ciático em sua porção média até a porção distal de seus ramos: nervo fibular, sural e tibial, conforme demonstrado na figuras 2 e 3 . 


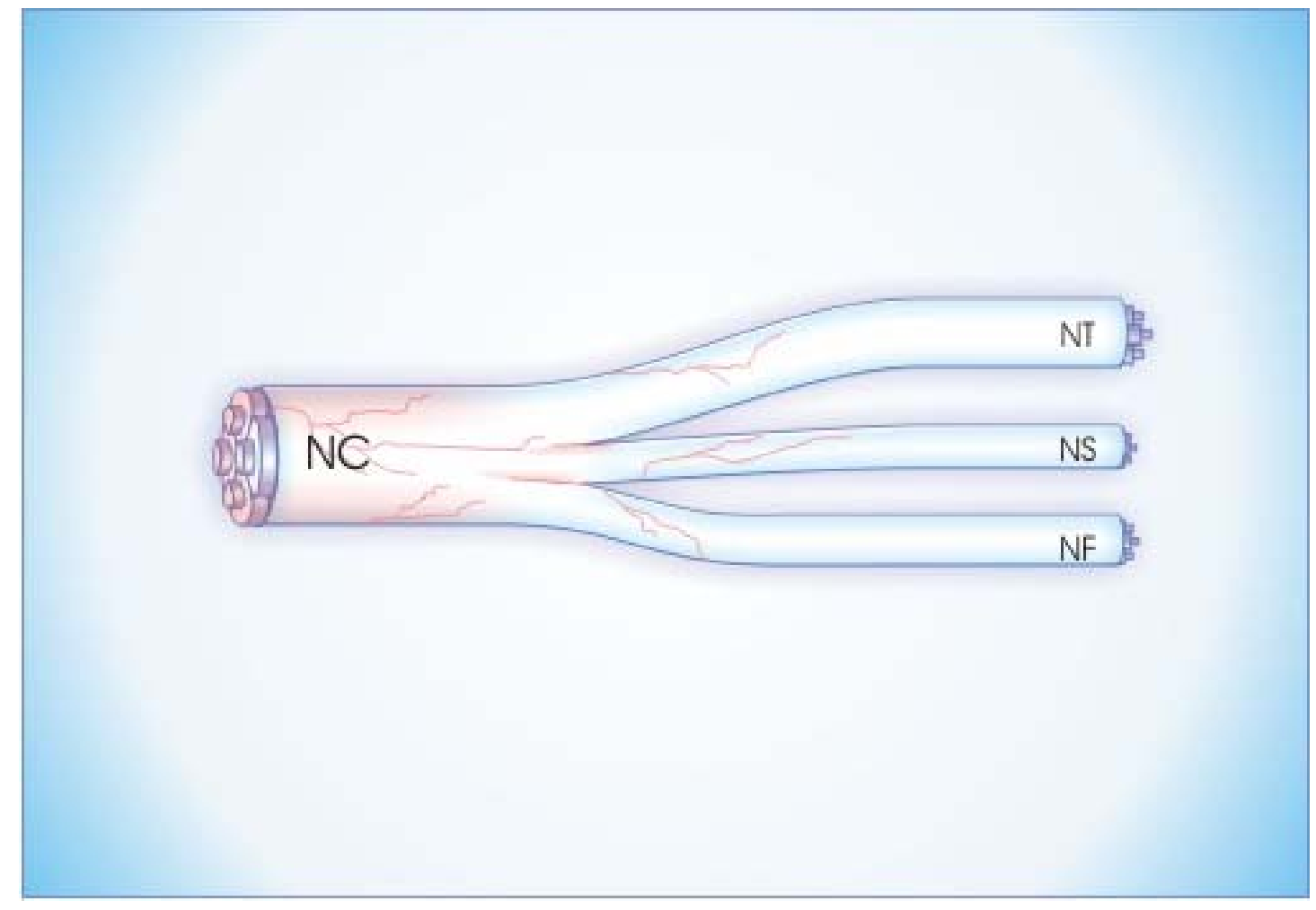

Figura 2. Representação esquemática: tronco do nervo ciático (NC), demonstrando suas ramificações: (NT) nervo tibial posterior, (NS) nervo sural e (NF) nervo fibular. 


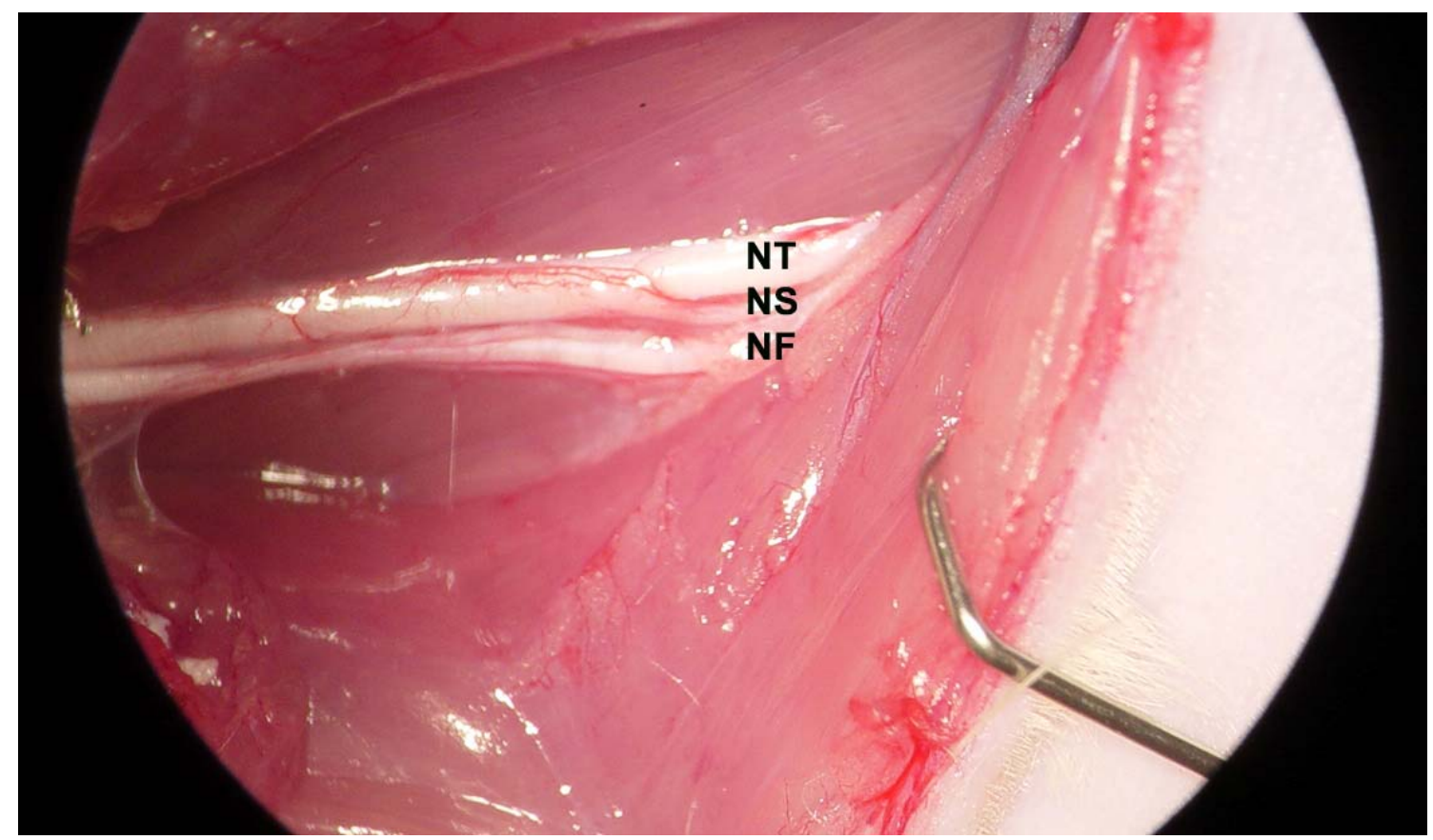

Figura 3. Ramificações do nervo ciático: (NT) nervo tibial posterior, (NS) nervo sural e (NF) nervo fibular. (10x)

Utilizando-se de instrumental microcirúrgico e sob magnificação com aumento a 10 vezes, foram ressecados segmentos de nervo fibular, de modo a se produzir defeito de $5 \mathrm{~mm}$ de extensão a $5 \mathrm{~mm}$ distalmente da divisão do nervo ciático. A figura 4 demonstra esquematicamente o modelo adotado. 


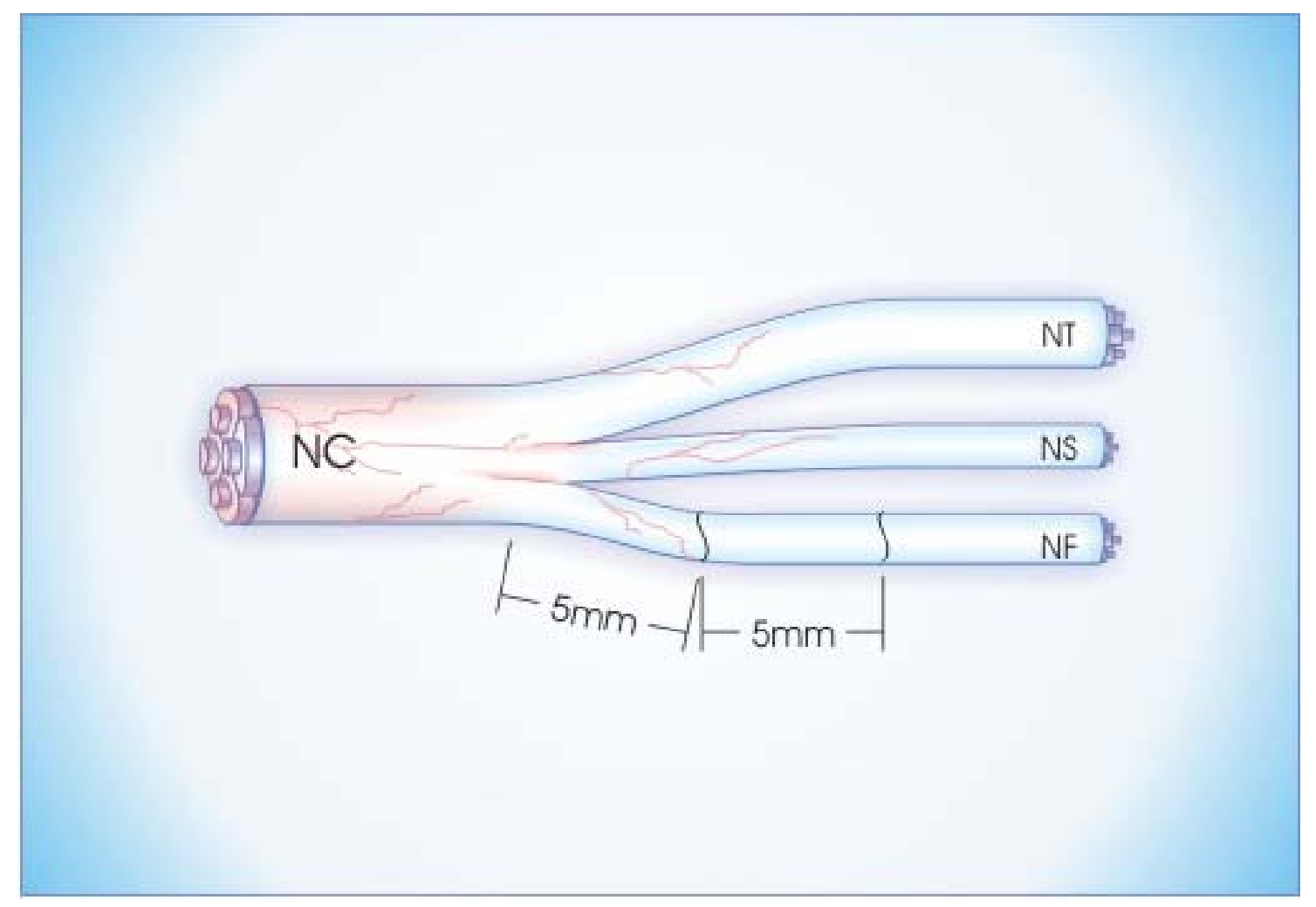

Figura 4. Demonstra a localização exata de secção do nervo fibular (NF) de 5 mm de comprimento e a $5 \mathrm{~mm}$ de sua origem no nervo ciático.Tronco do nervo ciático (NC), o nervo tibial posterior (NT) e o nervo sural (NS).

O segmento ressecado foi ressuturado em sua posição (funcionando como um enxerto de nervo autógeno) com quatro pontos epineurais separados com fio monofilamentar nylon 10-0 (Ethicon®) e agulha BV-6, conforme demonstrado esquematicamente na figura 5. 


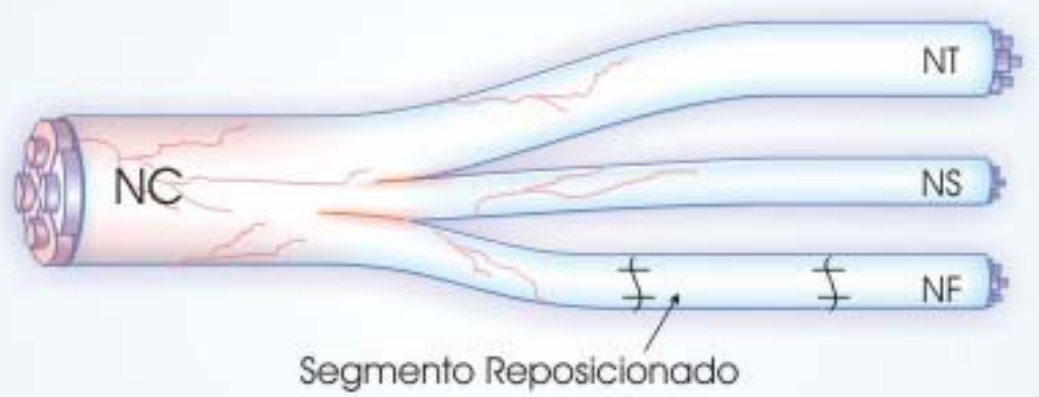

Figura 5. Modelo esquemático demonstrando o reposicionamento do segmento de nervo autógeno previamente retirado através de sutura com fio monofilamentar de nylon 10.0. NC: nervo ciático, NF: nervo fibular, NS: nervo sural e NT: nervo tibial posterior.

Para o preparo do material a ser utilizado no grupo $B$, veias jugulares dos ratos do mesmo grupo foram separadas para cada espécime, através de uma incisão na porção paramediana cervical e isolamento da veia jugular interna com ressecção de $1 \mathrm{~cm}$ de sua extensão sendo ligados seus cotos distal e proximal com fio de algodão 4.0 , conforme figura 6 . 


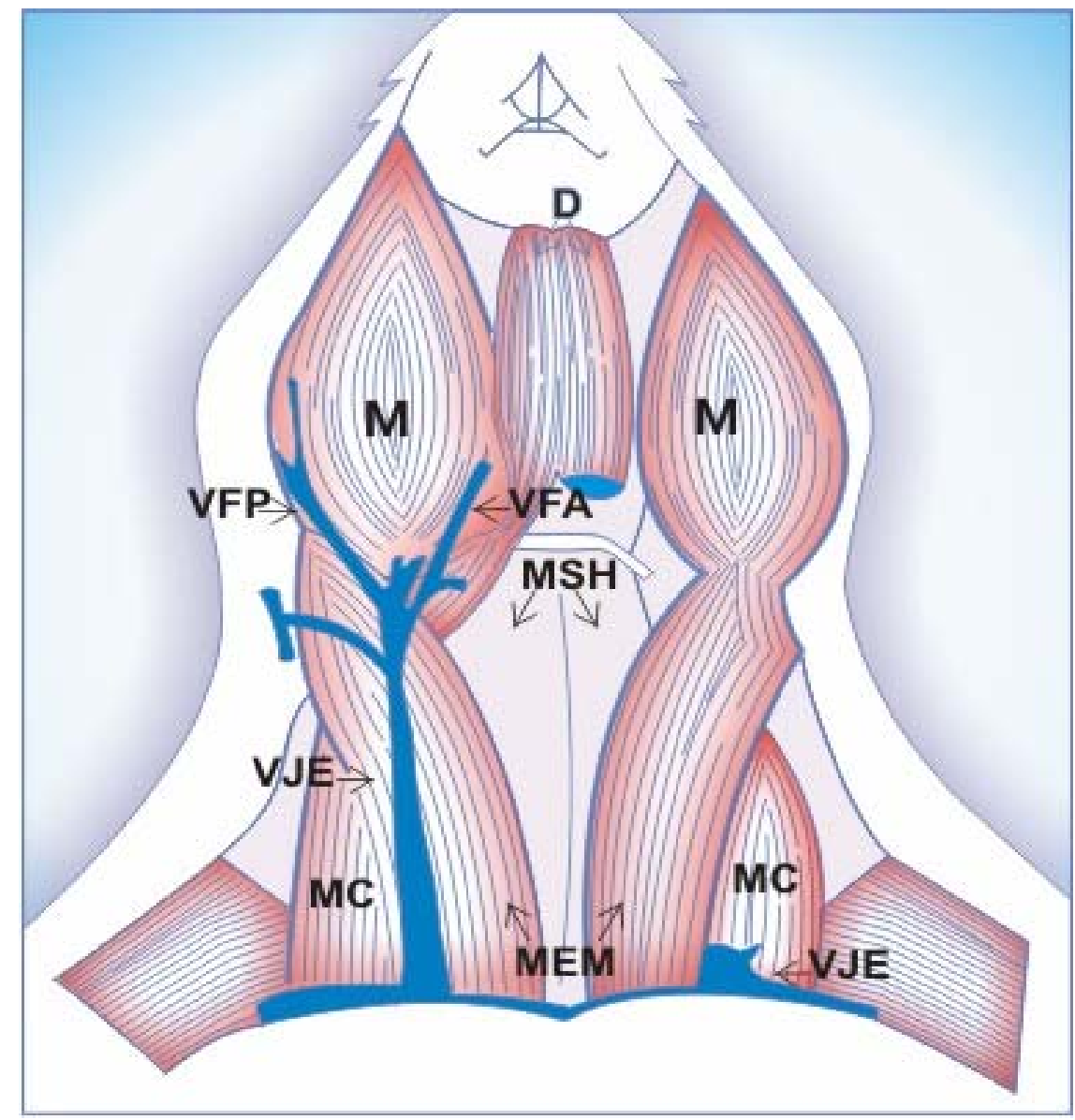

Figura 6. Modelo esquemático da região cervical anterior do rato, demonstrando a veia jugular externa (VJE) e a musculatura cervical superficial. (M) - Músculo Masseter; (D) - Músculo digástrico; (MSH) - Músculo esternohiodeo; (VFP) - Veia Facial Posterior; (VFA) - Veia Facial Anterior; (MC) - Músculo clavotrapezóide; (MEM) - Músculo esternocleidomastoideo.

A sutura da pele foi feita com fio de nylon 6.0. As veias extraídas foram tratadas em glicerol a $98 \%$, sendo conservadas em recipientes apropriados e identificados para cada animal, tendo-se o cuidado de retornar ao mesmo animal, a mesma veia, após o tratamento em geladeira a $4{ }^{\circ} \mathrm{C}$ por sete dias.

Depois de sete dias, cada animal foi colocado em decúbito ventral e tricotomizado na porção dorsal da pata direita. Através de uma incisão na face posterior da pata, fez-se a diérese da musculatura ventral até se obter a 
exposição do nervo fibular desde a sua ramificação do nervo ciático até próximo à região do músculo extensor dos dedos.

Com auxílio de microscópio e instrumental microcirúrgicos, foram ressecados segmentos do nervo fibular, de modo a se produzir defeito de $5 \mathrm{~mm}$ de extensão a $5 \mathrm{~mm}$ de sua origem do nervo ciático . Então, após lavagem ostensiva das veias jugulares conservadas em glicerol, com soro fisiológico a 0,9\%, em temperatura ambiente, cada veia extraída, foi mantida em frasco separado, contendo solução de soro fisiológico a 0,9\%\%, por 30 minutos, para reidratação da mesma.

Em seguida, a veia jugular foi suturada ao nervo fibular através de um ponto em "U" de fio monofilamentar nylon 10-0 (Ethicon®) com agulha BV-6, passado em cada extremidade da seguinte maneira: de fora para dentro na veia, atravessando o epineuro no coto do nervo e voltando na veia de dentro para fora, devendo a veia cobrir $2.5 \mathrm{~mm}$ de cada coto do nervo. Procedimento feito de forma igual em cotos proximal e distal. Em seguida, realizo-se o fechamento por planos da musculatura e pele com fio de nylon 6.0. (figura 7) 


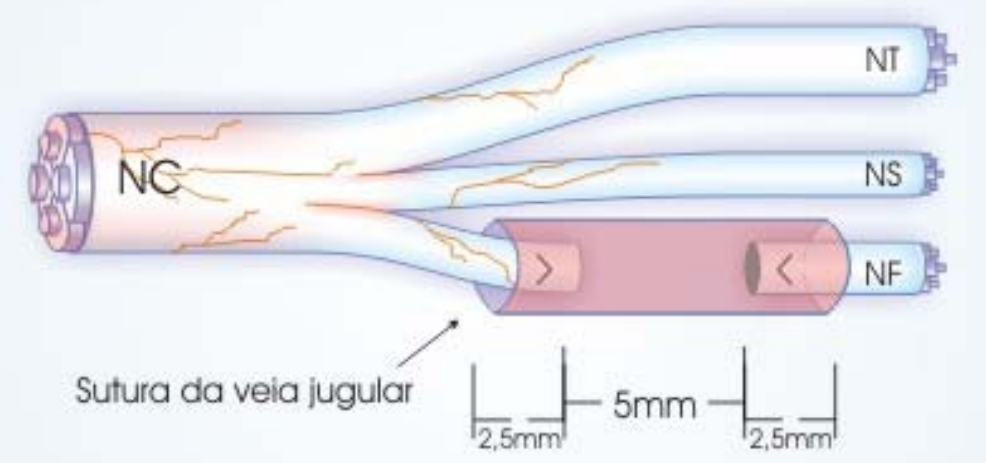

Figura 7. Modelo esquemático da interposição de veia conservada em glicerol (grupo B) para tubulização de defeito de $5 \mathrm{~mm}$ em nervo fibular. Nota-se que o comprimento da veia é de $10 \mathrm{~mm}$ e que esta recobre $2,5 \mathrm{~mm}$ do coto proximal e $2,5 \mathrm{~mm}$ do coto distal, além da fixação em cada coto com ponto em "u".

Para a transferência de material para os animais do grupo C, Cinco Ratos doadores Sprague-Dawley foram submetidos à exerese de fragmentos de nervos fibulares para o preparo de nervos conservados em glicerol para que fossem posteriormente utilizados como nervos alógenos (aloenxertia de nervo).

A extração do nervo fibular para posterior transferência é realizada após anestesia do rato, com metodologia semelhante à utilizada para os grupos $A, B$ e C: retirada de segmento de $5 \mathrm{~mm}$ de nervo fibular da pata direita do rato, após exposição cirúrgica por diérese cuidadosa nos planos cirúrgicos, com o rato posicionado em decúbito ventral.

O fragmento de nervo fibular alógeno (raça Sprague-Dawley) permaneceu estocado em tubo individual identificado com $20 \mathrm{ml}$ de solução de glicerol a 
$98 \%$ e refrigerado em temperatura de $4^{\circ} \mathrm{C}$ por período de 7 dias. Antes da realização da enxertia, os nervos foram mantidos em solução de soro fisiológico a $0.9 \%$ por 30 minutos.

A aloenxertia para o grupo C utilizou a mesma técnica de interposição de nervo aplicada no grupo A já descrita anteriormente. Conforme demonstram as figuras número 8 e 9.

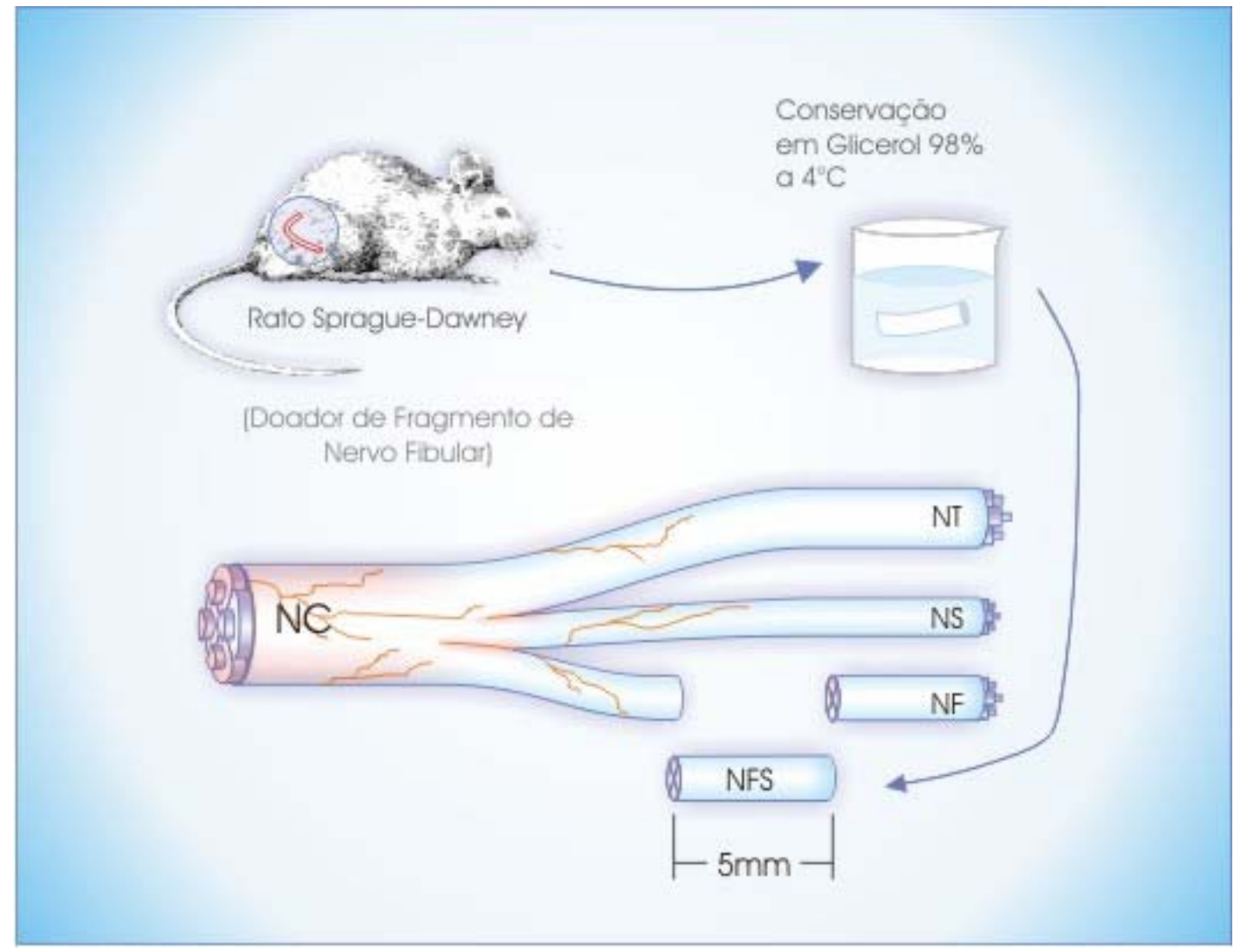

Figura 8. Modelo esquemático da interposição de nervo alógeno conservado em glicerol (grupo C) para tratamento de defeito de $5 \mathrm{~mm}$ em nervo fibular de rato Wistar, após sua retirada em rato doador de espécie diferente (Sprague- Dawley) e conservação por sete dias em glicerol a $98 \%$ em refrigeração a $4^{\circ} \mathrm{C}$. NC: nervo ciático, NFS: nervo fibular de rato doador, NS: nervo sural e NT: nervo tibial posterior. 


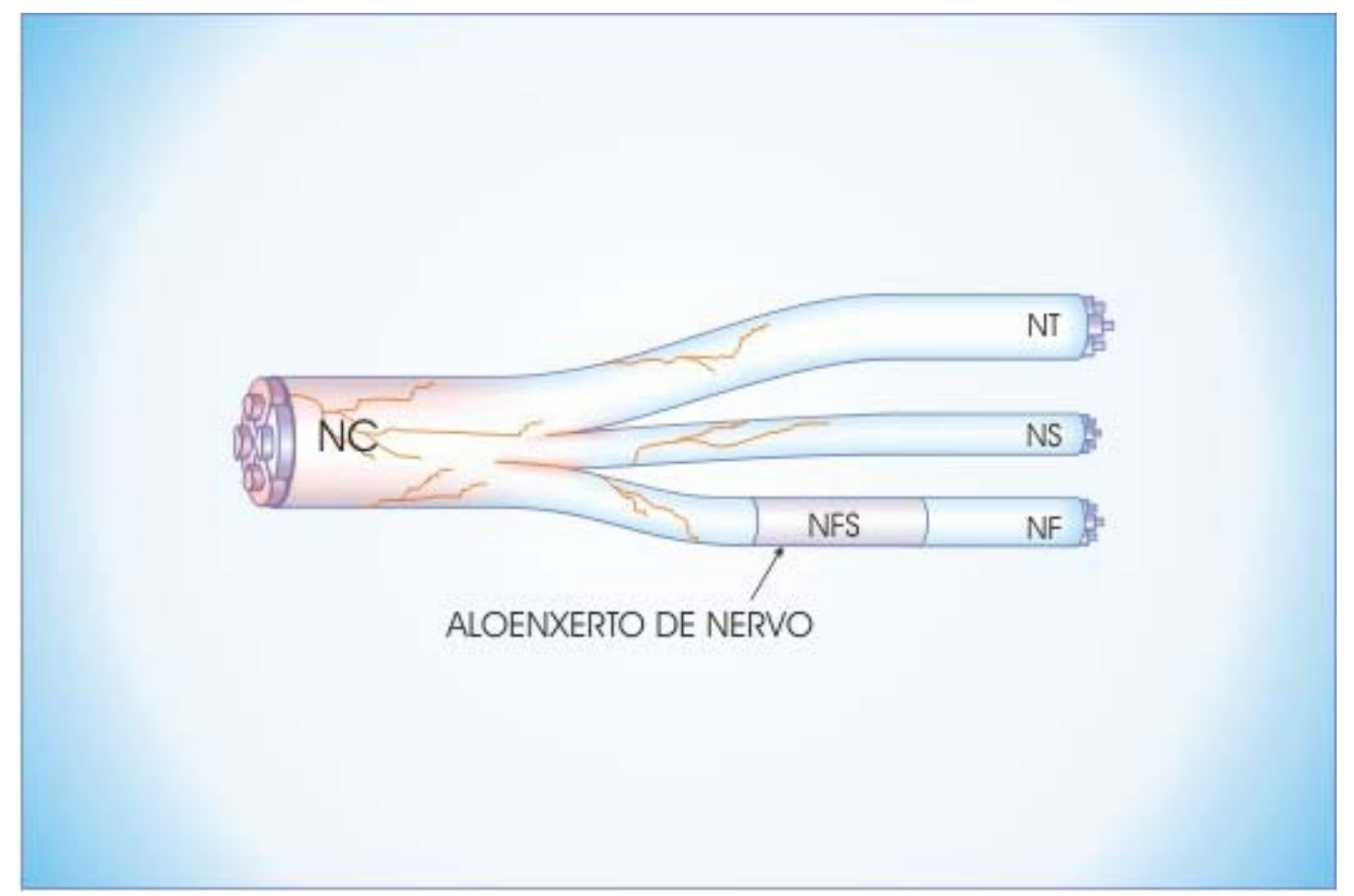

Figura 9. Modelo esquemático demonstrando o reposicionamento do segmento de nervo alógeno previamente retirado de rato Sprague-Dawley, através de sutura com fio monofilamentar de nylon 10.0. NC: nervo ciático, NFS: nervo fibular de rato doador, NS: nervo sural e NT: nervo tibial posterior.

Ao término do procedimento cirúrgico, os animais foram mantidos em gaiolas separadas e com identificação conforme grupo, sob aquecimento, até total restabelecimento de suas funções vitais. Nos dias subseqüentes, foram mantidos com água e ração "ad libitum" até a data do sacrifício.

Os animais foram sacrificados através de eutanásia com uma sobre dose de anestésico (pentobarbital sódico), por via intraperitonial. Os animais foram desprezados em lixo biológico existente no Instituto de Ciências Biomédicas da Universidade de São Paulo. 
Avaliação da Regeneração Neural

A regeneração neural dos grupos $A, B$ e $C$ foi avaliada com base em análises de parâmetros histológicos e também por meio de um teste funcional: "walking track analysis" (De Medinacelli et al , 1982; Bain et al ,1989; Costa, 1995; Costa , 2006 ; Cunha e Costa, 2007).

Histologia Qualitativa

Para a análise histológica, padronizou-se a coleta de fragmento da porção média do segmento interposto, desta forma evitou-se a área de sutura em ambos os grupos.

O material foi fixado em solução de glutaraldeído a 2 \% e em solução de tetróxido de ósmio a 1\%, incluído em resina pura de peróxido de bezoíla a 1\% e hidroxietilmetacrilato. Realizou-se cortes transversais de 2 micras de espessura, corados com azul de toluidina a 1\%, para uma varredura mais rigorosa.

Nos cortes analisou-se a arquitetura geral do nervo regenerado, procurando-se identificar o padrão geral de organização do tecido neural dentro dos enxertos venosos, o grau de mielinização e da reorganização axonal, a disposição dos fibroblastos e do tecido conjuntivo epiperineurais, a presença de escape de fibras axonais para fora dos limites do epineuro e a análise da reação tecidual (Costa, 1996; Costa, 2006; Cunha e Costa, 2007). 
Avaliação Funcional

O grau de recuperação funcional associado à regeneração neural foi avaliado pelo estudo dos padrões de deambulação dos ratos no pré-operatório e no pós-operatório (imediato, 3 semanas e no momento do sacrifício - 6 semanas), através da análise das pegadas impressas pelas patas posteriores dos animais ("walking track analysis"), de acordo com o método previamente descrito por De Medinaceli (1982) e modificado por Bain (1989).

Mergulharam-se as patas traseiras dos animais em tinta azul, sendo colocados, um por um, para caminharem em um corredor sobre papel branco, de modo a deixarem suas pegadas impressas. As folhas de impressão foram identificadas para cada animal e o exame foi repetido sempre que se considerou que as impressões tivessem borrado, seja por excesso de tinta ou por um deslize do animal no momento da caminhada.

Foram coletadas as distâncias das impressões entre o primeiro e quinto dedos (extensão dos dedos - ED) e o comprimento da pegada (CP) (fig. 10).

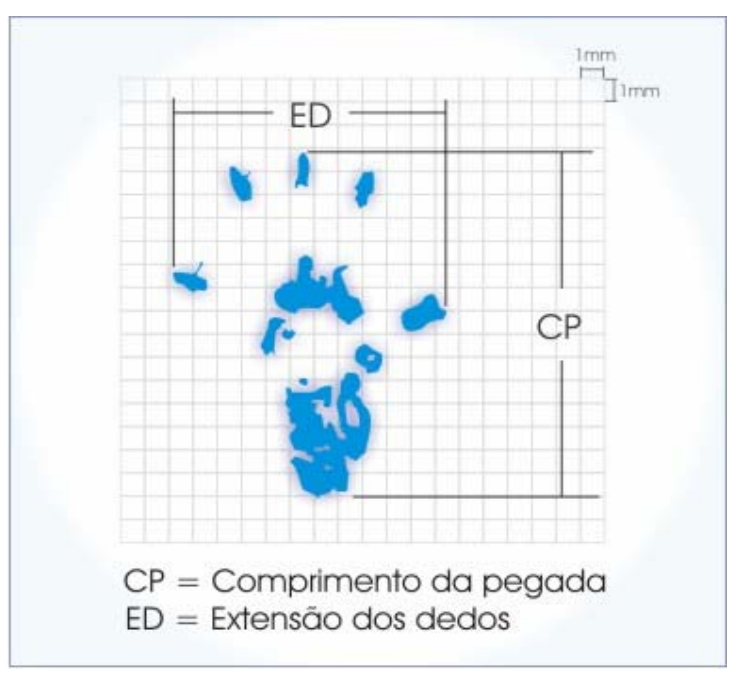

Fig. 10 - Demonstram-se na impressão da pata do rato as medidas necessárias para quantificação do índice de função do nervo fibular. (De Medinaceli, 1982). 
Estes dados foram colhidos para os cálculos dos índices de função do fibular (IFF) de cada animal, utilizando-se a fórmula proposta por Bain et al (1989):

$I F F=174.9 \times[(C P O-C P N) \div C P N]+80.3 \times[(E D O-E D N) \div E D N]-13.4$

onde:

$\mathrm{CPO}=$ comprimento da pegada da pata operada

$\mathrm{CPN}=$ comprimento da pegada da pata normal

EDO = extensão dos dedos da pata operada

EDN = extensão dos dedos da pata normal

sendo:

IFF = próximo a zero $\rightarrow$ função motora normal do nervo fibular

IFF = próximo a $-100 \rightarrow$ completa disfunção.

Utilizando-se dos dados apresentados pelos grupos em relação ao IFF do pós-operatório e submetendo-os a análise estatística pelo método de variância com medida repetida e um fator, seguida de comparações múltiplas pelo método de Bonferroni, foi demonstrado a variação do IFF em relação ao tempo de pós-operatório (Costa, 1996; Costa, 2006; Cunha e Costa, 2007). 


\section{RESULTADOS}

Durante as seis semanas do estudo, todos os animais mantiveram-se saudáveis, não tendo sido observada infecção da ferida cirúrgica, nem a presença de úlceras plantares neuro-distróficas.

No momento do sacrifício, o Grupo A (auto-enxerto), demonstrava macroscopicamente, enxertos intactos, sem neuromas visíveis nas linhas de sutura e pouca aderência a tecidos adjacentes. 
O Grupo B (veia autógena + glicerol) apresentou pouca aderência entre as veias e os tecidos adjacentes, com uma fina camada de tecido fibroso envolvendo externamente as veias. Não foram observados neuromas ou colabamento das veias.

No grupo C (nervo alógeno + glicerol) também não se observaram neuromas e havia pouca aderência a tecidos adjacentes, de forma muito semelhante ao grupo A (auto-enxerto).

Analise Histológica

Na análise microscópica das lâminas do Grupo A (auto-enxerto) nota-se que o auto-enxerto conservou o epineuro, caracterizado pela presença de células fusiformes e uma bainha fibrosa delgada. No interior deste invólucro é possível delimitar a presença de vasos sanguíneos em pequena quantidade.

Visualizaram-se pequenos fascículos contendo axônios mielinizados e de tamanhos variados. A degeneração walleriana está presente, mas em pequeno número de axônios. Evidencia-se também o escape de fibras axonais 
mielinizadas para fora dos limites do epineuro em todos os 5 animais do grupo

(figuras 11 e 12).

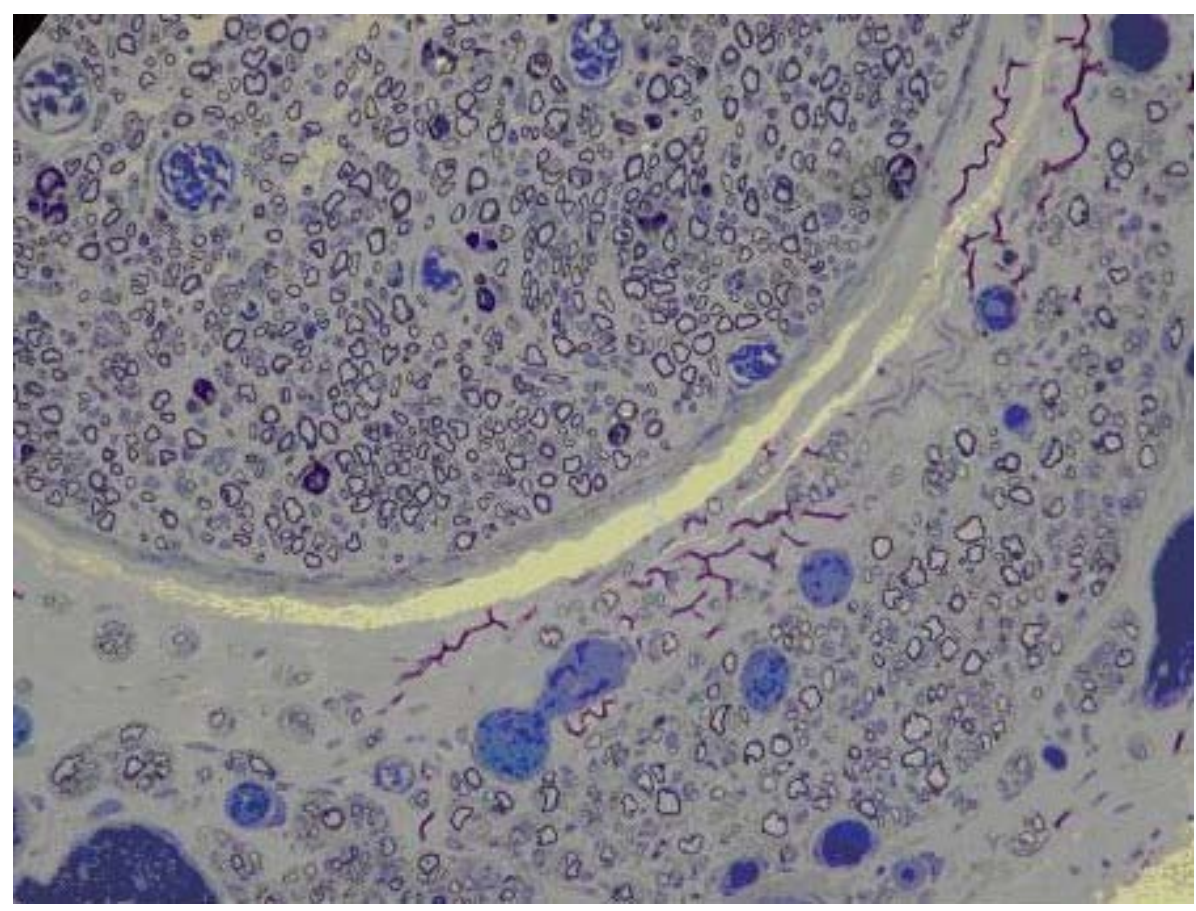

Figura 11. Grupo A (auto-enxerto): escape de fibras regeneradas para fora dos limites do epineuro do auto-enxerto (200X).

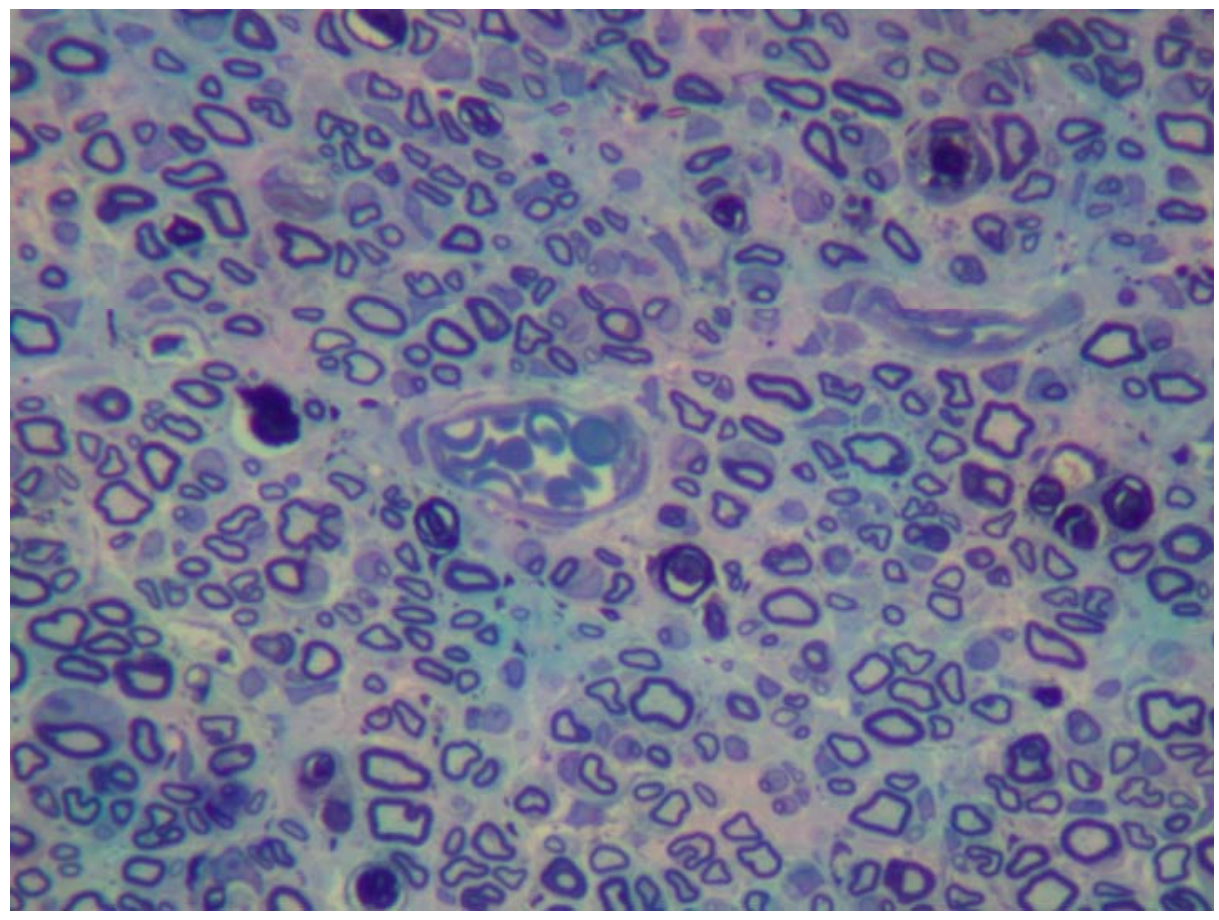


Figura 12. GRUPO A (auto-enxerto). Minifascículos de axônios, em sua maioria, mielinizados e de variados diâmetros. (400x).

Nos cinco animais do Grupo B (veia autógena+ glicerol) houve menor reação tecidual perineural e menor quantidade de escape axonal quando comparada ao Grupo A (auto-enxerto). As veias conservadas em glicerol apresentaram sua estrutura preservada e facilmente distinguível do tecido neural. Nota-se uma grande quantidade de vasos neoformados em permeio aos fascículos formados pelos axônios neurais, esses, em sua grande maioria, mielinizados, porém de diâmetro relativamente inferior e contendo menos axônios em comparação aos fascículos do grupo A (auto-enxerto) (figuras 13 e 14). 


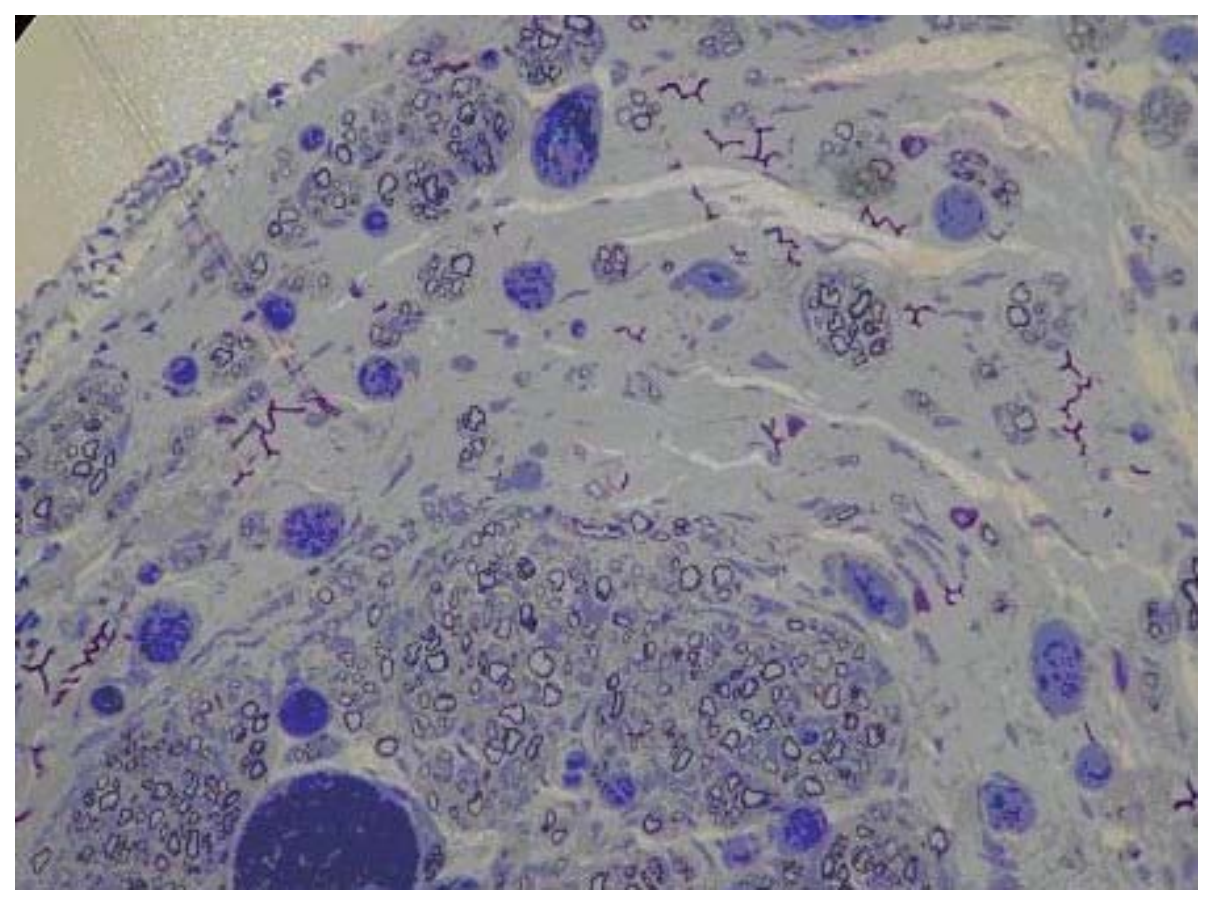

Figura 13. Grupo B (veia autógena + glicerol): corte histológico com presença de pequena reação tecidual perineural e escape axonal fora dos limites do epineuro (200X).

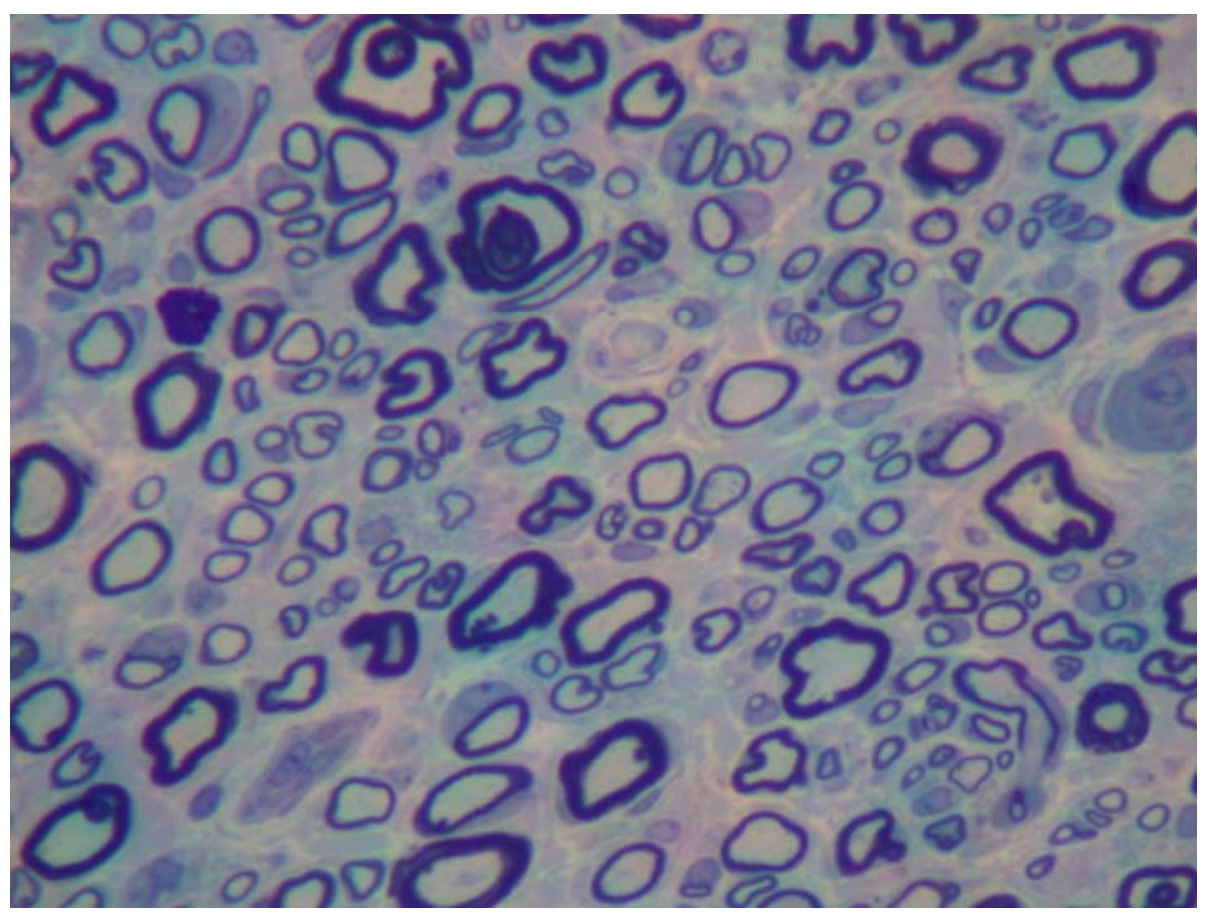


Figura 14. Grupo B (Veia autógena + Glicerol): Demonstra-se minifascículos de axônios, a sua maioria mielinizados e de diâmetros variados. (400x).

No Grupo C (nervo alógeno + glicerol) os achados histológicos foram semelhantes aos encontrados no grupo B (veia autógena + glicerol). O aloenxerto conservou o seu epineuro, sendo possível a visualização de uma bainha fibrosa localmente. No interior deste invólucro notamos a presença de neoangiogênese em pequena quantidade. Os fascículos formados pelos agrupamentos de axônios eram pequenos, com poucas fibras axonais, em sua maioria mielinizadas e de diâmetros variados. A degeneração Walleriana de fibras axonais estava presente, mas em pequena quantidade. $\mathrm{O}$ escape de fibras axonais mielinizadas para fora dos limites do epineuro e a reação tecidual perineural foram de baixa intensidade e inferiores em relação ao grupo A (auto-enxertia) (figuras 15 e 16). 


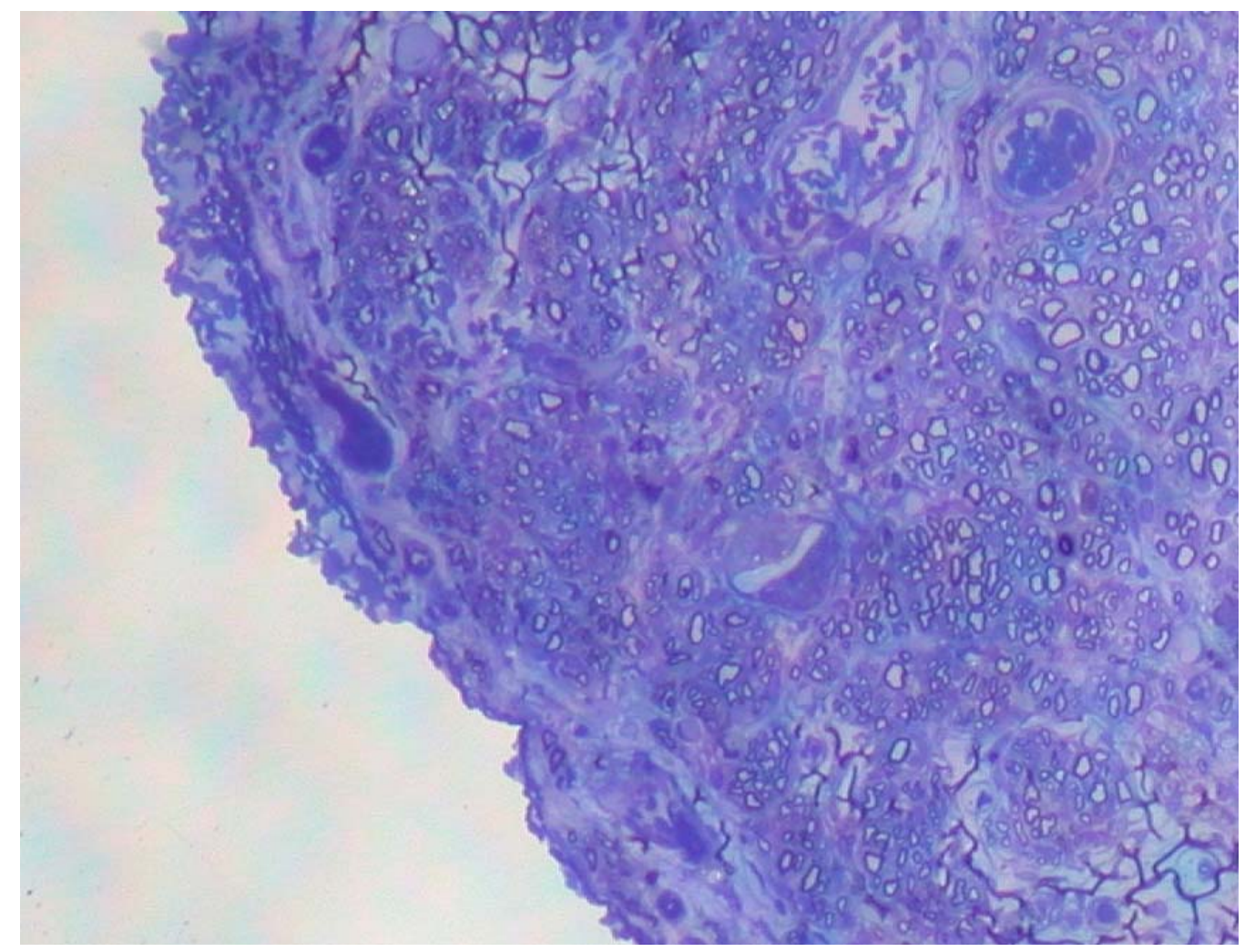

Figura 15. Grupo C (aloenxerto de Nervo + Glicerol): corte histológico com presença de pequena reação tecidual perineural e escape axonal fora dos limites do epineuro (200X). 


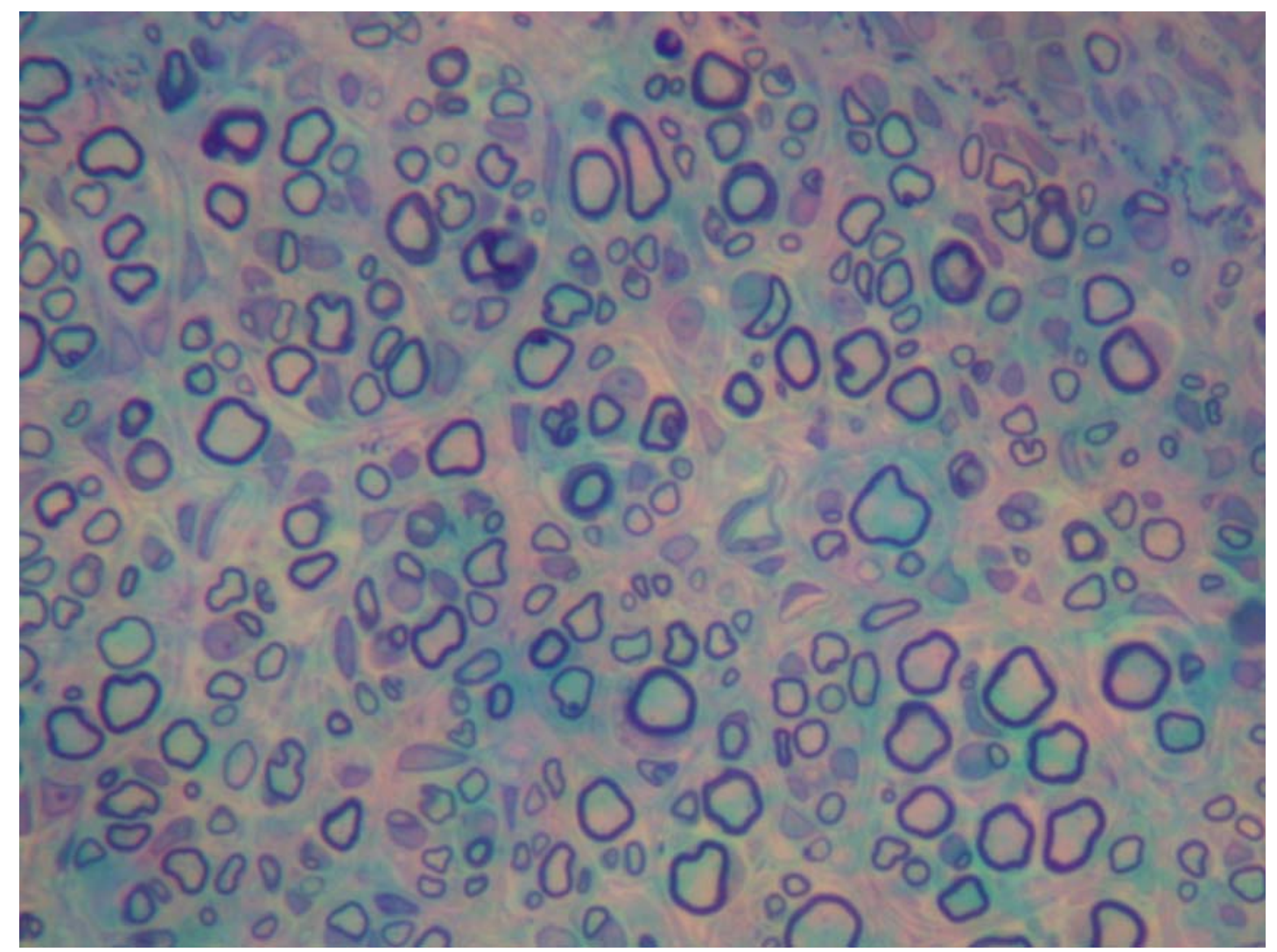

Figura 16. Grupo C (nervo alógeno + glicerol): Disposição dos axônios em minifascículos, em grande parte, mielinizados e de variados diâmetros (400x).

\section{ESTUDO FUNCIONAL}

A figura 17 mostra a representação de uma pegada normal da pata traseira direita antes do momento operatório, e a figura 18 mostra o aspecto das pegadas dos ratos no pós-operatório imediato, 3 e 6 semanas após tratamento dos três grupos avaliados. 


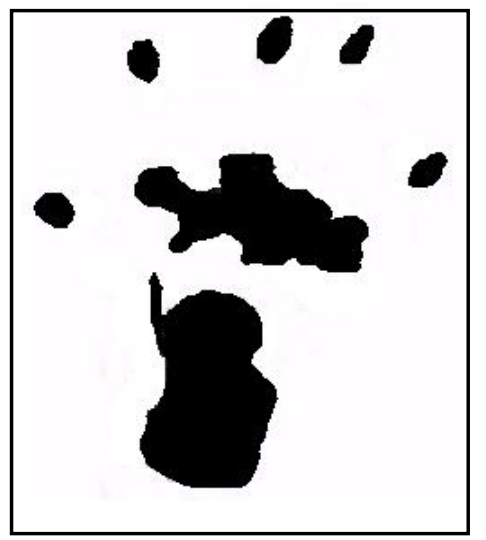

Figura 17. Aspecto normal da pegada da pata traseira direita dos ratos no pré-operatório (sem lesão do nervo fibular).

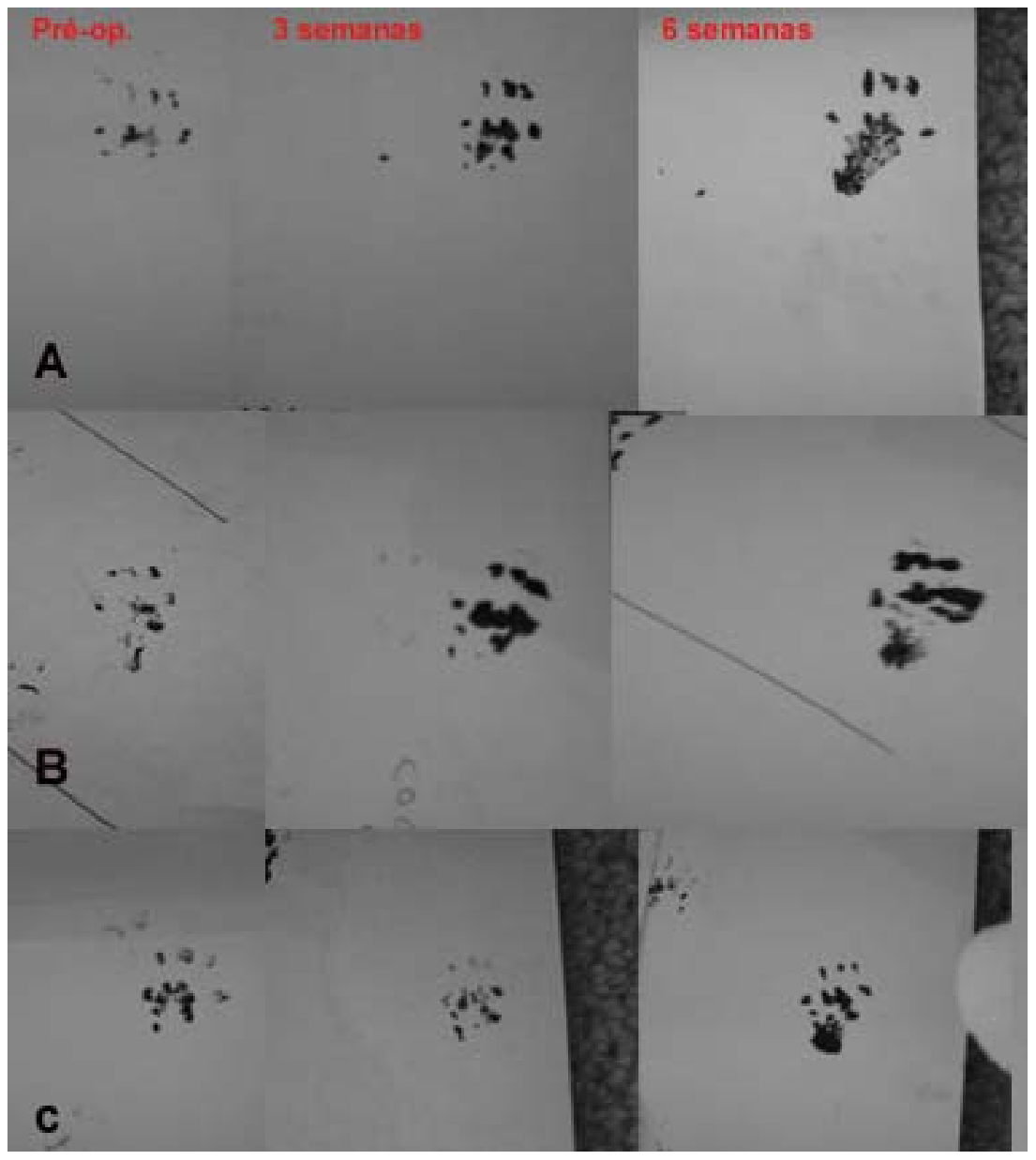

Figura 18. Aspecto das pegadas dos ratos no pré e pós-operatório dos três grupos. 
Na figura 18 é possível ver a evolução do comprimento da pegada e da extensão dos dedos durante os períodos de pós-operatório imediato, 3 e 6 semanas de pós-operatório.

Os valores médios dos IFF (índice de função do nervo fibular), no préoperatório e no pós-operatório (imediato, 3 e 6 semanas), calculados para cada grupo estão apresentados na tabela 2 e representados no gráfico 1.

Tabela 2: Medidas descritivas de IFF, em cada grupo, ao longo do tempo.

\begin{tabular}{|c|c|c|c|c|c|}
\hline Grupo & & Pré op & Pós op & 3 semanas & 6 semanas \\
\hline \multirow[t]{4}{*}{ Auto-enxerto } & Média & $-7,79$ & $-88,96$ & $-63,79$ & $-24,51$ \\
\hline & DP & 0,23 & 8,01 & 6,59 & 10,79 \\
\hline & Mínimo & $-8,10$ & $-102,23$ & $-74,60$ & $-37,40$ \\
\hline & Máximo & $-7,57$ & $-80,74$ & $-57,13$ & $-13,38$ \\
\hline \multirow[t]{4}{*}{ Veia Autógena + glicerol } & Média & $-6,30$ & $-83,57$ & 57,68 & $-27,36$ \\
\hline & DP & 2,42 & 9,08 & 12,75 & 11,43 \\
\hline & Mínimo & $-8,26$ & $-95,79$ & $-68,06$ & $-40,73$ \\
\hline & Máximo & $-2,80$ & $-73,50$ & $-41,61$ & $-11,57$ \\
\hline \multirow[t]{4}{*}{ Nervo Alógeno+ glicerol } & Média & $-7,67$ & $-96,04$ & $-71,76$ & $-34,36$ \\
\hline & DP & 2,87 & 7,50 & 7,24 & 14,48 \\
\hline & Mínimo & $-11,41$ & $-107,87$ & $-80,24$ & $-53,44$ \\
\hline & Máximo & $-3,34$ & $-87,76$ & $-64,36$ & $-17,03$ \\
\hline
\end{tabular}




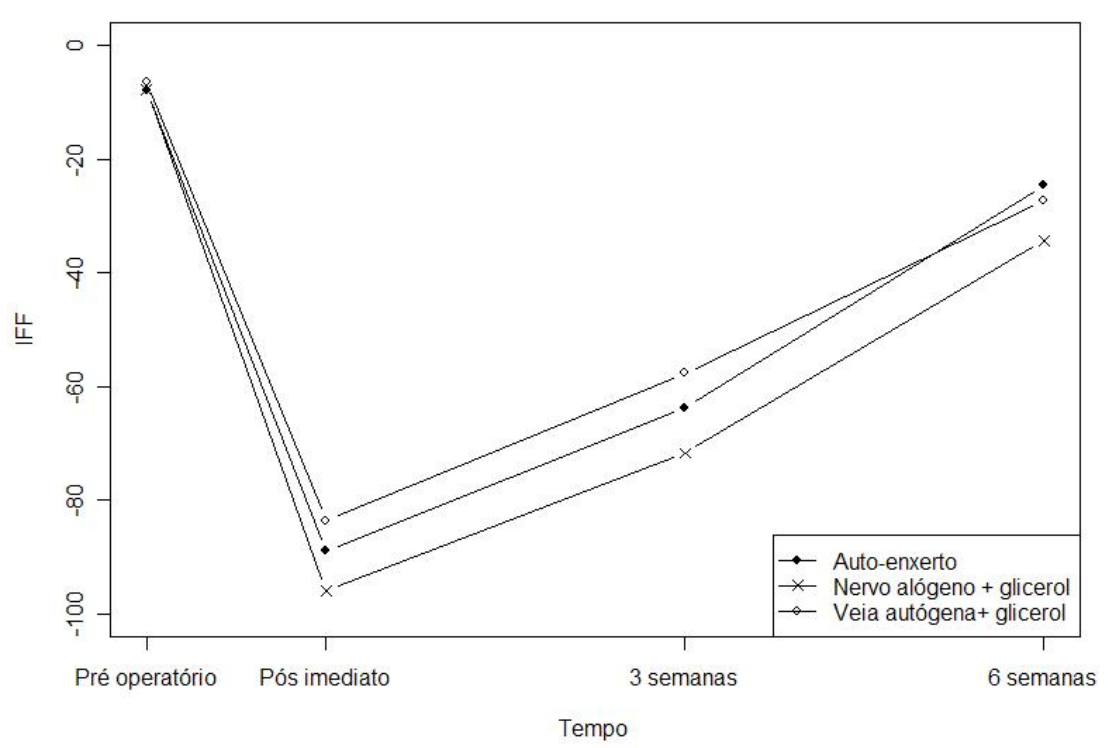

Gráfico 1. Perfis médios da variável IFF em cada grupo durante o tempo de estudo, iniciado no préoperatório e o seguimento no pós-operatório imediato, 3 e 6 semanas

A análise estatística da recuperação funcional determinada pelo IFF (índice de função do nervo fibular) foi realizada pelo o modelo de análise de variância com medidas repetidas (Winer, 1971) e o método de comparações múltiplas de Bonferroni $(p<0.05)$.

Os IFF observados no pré-operatório foram: no Grupo A (auto-enxerto) em média de - 7,79 +- 0,23; no Grupo B (veia autógena + glicerol) de - 6,30 +2,42 e no Grupo C (nervo alógeno + glicerol) de - 7,67+- 2,87.

A análise estatística não mostrou diferença estatisticamente significativa entre os três grupos em relação IFF no pré-operatório.

Os IFF do pós-operatório imediato foram, respectivamente, em média: Grupo A (auto-enxerto) - 88,96+- 8,01; Grupo B (veia autógena + glicerol) 83,57+-9,08 e no Grupo C (nervo alógeno + glicerol) -96,04+- 7,50. A análise estatística não mostrou diferença estatisticamente significativa entre os três grupos em relação ao índice IFF no pós-operatório imediato. 
Os IFF do pós-operatório dos três grupos em 3 semanas foram, respectivamente, em média: Grupo A (auto-enxerto) - 63,79+-6,59 ; Grupo B (veia autógena + glicerol) - 57,68+- 12,75 e no Grupo C (nervo alógeno + glicerol) - 71,76+-7,24. A análise estatística não mostrou diferença estatisticamente significativa entre os três grupos em relação IFF no pósoperatório de 3 semanas.

Os IFF do pós-operatório de seis semanas foram, respectivamente, em média: Grupo A (auto-enxerto) - 24,51+- 10,79; Grupo B (veia autógena + glicerol) - 27,36+- 11,43 e no Grupo C (nervo alógeno + glicerol) - 34,36+14,48. A análise estatística não mostrou diferença estatisticamente significativa entre os três grupos em relação ao IFF no pós-operatório de 6 semanas. 


\section{DISCUSSÃO}

A auto-enxertia de nervo é o tratamento cirúrgico de escolha para os casos de lesões de nervos que acometam um segmento maior do que aquele onde seja possível realizar reaproximação simples e rafia com fio micro cirúrgico.

No entanto, criticas devem ser feitas a esta metodologia principalmente pela morbidade que pode ser produzida ao se retirar um segmento de nervo autólogo de uma região antes normal. Esta retirada produz um déficit com várias repercussões clínicas locais, dentre elas, parestesia e dor crônica na região de coleta do nervo doador (ljpma et al, 2006).

Também é importante frisar que a auto-enxertia não é aplicável a todas as intervenções cirúrgicas de reparação de nervos periféricos, principalmente quando a quantidade de nervo autógeno disponível é insuficiente para cobrir as distâncias a serem reconstruídas ou pela necessidade de múltiplos reparos na correção de lesões de nervos calibrosos (Colohan et al, 1996; Terzis et al, 2007).

O índice de sucesso da técnica de auto-enxertia em relação ao nível de recuperação funcional alcançado nem sempre é satisfatório, ou por vezes, é comparável a resultados de outras técnicas, como uso de tubos sintéticos, veias frescas, veias invertidas e vasos conservados em glicerol. (Lundborg et al 1981 e 1982, Garrity et al, 1955; Brunelli, 1982 e 1987; Chiu et al, 1982; Rice e Berstein, 1984; Costa, 1995; Costa et al, 2006; Cunha e Costa, 2007). Outro fato importante é que a coleta de um nervo autógeno para enxertia há um acréscimo no tempo cirúrgico. (Rappaport et al, 1993). 
A procura por novas técnicas que substituíssem a enxertia de nervo para tratamento de grandes perdas de tecido neural sem os danos causados a área doadora, perda de tempo cirúrgico e melhora dos resultados funcionais se torna cada vez mais uma tendência na Literatura sobre regeneração neural. Uma dessas possibilidades é a utilização de nervos alógenos preservados em glicerol realizado nesse trabalho.

Quanto ao modelo experimental, o rato como animal de escolha já foi utilizado por vários estudos na Literatura, sendo sua utilização propicia na realização de experimentos com nervos periféricos. A disponibilidade de espécimes, o seu manuseio e cuidados já são muito bem conhecidos e documentados. (Rosen et al, 1983; Seckel et al, 1984; Keeley et al, 1991; Phan et al,1991; Buttemeyer et al, 1995; De medinacelli et al, 1995; Eang et al, 1997; Carter et al , 1998; Doolabh et al , 1998; Gold et al, 1999; Hazari et al, 1999).

O uso de anestesia com o pentobarbital sódico por via intraperitonial para o rato em estudos experimentais já é aceito e corrente há vários anos em estudos de nervos periféricos (Zhang et al, 2005; Costa et al, 2006; Cunha e Costa, 2007).

O microscópio como ferramenta fundamental na manipulação dos nervos periféricos e realização de suturas já era citado como peça indispensável nos trabalhos de Stancic et al, em 1998. A sutura do tipo epineural com pontos simples de fio microcirúrgico também é técnica encontrada em diversos trabalhos experimentais (Carter, 1998; Davison, 1999; Hazari et al, 1999; Tuma Jr , 1997). 
Outra vantagem de experimentos feitos com ratos é a possibilidade de estudo da análise funcional do nervo ciático ou de seu ramo tibial ou fibular por meio da técnica de "Walking track analysis", metodologia bastante conhecida e utilizada no meio científico. Estabelecida inicialmente por De Medinacelli, tratase de um teste não invasivo, rápido e de custo baixo que pode ser utilizado antes do tempo operatório e durante o período de recuperação funcional (Wang et al, 1993; Buttemeyer , 1995; De Medinacelli, 1995; Doolabh e Mackinnon , 1999; Kayikçioglu et al, 1999; Mohammad et al , 2000).

Em 1989, Bain et al, modificaram a metodologia de De Medinacelli para possibilitar a diferenciação de lesões de nervo ciático, nervo tibial posterior e nervo fibular. Dessa forma, tornaram possível o desdobramento do exame e trouxeram a possibilidade de alterações metodológicas que privilegie um só tipo de lesão, ao contrário da lesão total do nervo ciático. Esse fato inclusive facilita análise de resultados, permitindo a comparação entre diversas técnicas de reparação neural (Seckel et al, 1984; Buttemeyer, 1995; De Medinacelli, 1995; Gold et al, 1995; Wang et al, 1997; Doolabh e Mackinnon, 1998; Davison, 1999; Fansa et al, 1999; Hazari et al, 1999; Madison, 1999; Mohammad et al, 2000; Cunha e Costa, 2007).

Quanto à metodologia utilizada na abordagem cirúrgica desse experimento (padronização do tamanho do defeito de $5 \mathrm{~mm}$ em nervo fibular, auto-enxerto como grupo controle e tubulização com veias autógenas conservadas em glicerol) foi semelhante às realizadas por vários outros autores da literatura (Seckel et al, 1984; Fields et al, 1989; Keeley et al, 1991; Buttemeyer, 1995; Hazari et al, 1999; Li et al, 2004; Zhang et al, 2005; Costa et al, 2006; Cunha e Costa, 2007). 
A técnica de preparo dos cortes histológicos utilizando a fixação com tetróxido de ósmio e azul de toluidina é considerada a melhor técnica para a preservação e estudo da bainha de mielina em nervos periféricos (Rosen et al, 1983; Bora et al, 1987; Buttemeyer, 1995; Wang et al, 1995; Doolabh e Mackinnon, 1998; Kitahara et al, 2000; Costa et al 2006; Cunha e Costa, 2007).

Quanto aos períodos de análise funcional e análise histológica (de 3 e de 6 semanas para o sacrifício) é o mesmo utilizado por vários autores e é baseado no tempo decorrido para que o axônio atinja o coto distal do nervo fibular (Stancic et al, 1998; Fansa et al, 1999; Costa et al, 2006; Cunha e Costa, 2007).

Em relação a esse fato, Tseng em 2003 classificou as alterações histológicas da regeneração do nervo periférico de ratos em relação ao fator tempo nas seguintes fases: $1^{\mathrm{a}}$. Fase de hematoma (1 a 7 dias após a lesão); $2^{\mathrm{a}}$. Fase de migração celular (7 a 14 dias); $3^{\mathrm{a}}$. Fase de crescimento axonal (11 a 31 dias); 4ª . Fase de mielinização e maturação (após 31 dias). Desta forma, nesse estudo, os animais foram avaliados com 6 semanas, ou seja, na fase final de mielinização e maturação do nervo fibular reconstruído (Tseng et al, 2003).

Com relação à determinação dos grupos experimentais, temos: o grupo A (auto-enxerto) é o tratamento de escolha para a reparação de lesões de nervos com perda de substância suficiente para impedir reaproximação e sutura de bordos (Sunderland et al, 1978; Brunelli et al, 1994); o grupo B(veia autógena conservada em glicerol) é um método alternativo para enxerto de nervos, servindo como tubo condutor para reparo de pequenos defeitos neurais com 
resultados semelhantes ao auto-enxerto (Wolff et al, 1990; Cunha e Costa, 2007); o grupo C (aloenxerto de nervo conservado em glicerol) é um método com apenas uma citação prévia na literatura médica (Wolff et al, 1993) e com resultados semelhantes a auto-enxeria.

É importante ressaltar que o método de tubulização apresentados nos grupos $\mathrm{B}$ (veia autógena conservada em glicerol) e C(aloenxerto de nervo conservado em glicerol) apresentariam algumas vantagens em relação à autoenxertia: ausência de seqüela neural da área doadora, menor tempo cirúrgico e a possibilidade de grandes áreas doadoras na correção de grandes perdas de tecido neural.

É fato que o tubo condutor pode ser utilizado como alternativa ao enxerto de nervo para correção de defeitos inferiores a $2 \mathrm{~cm}$. (Dellon , 1995; Dellon e Mackinnon, 1988; Phan et al, 1991 , Cunha e Costa , 2007). Pode-se, por exemplo, optar durante uma exploração cirúrgica, por um debridamento mais intenso para diminuir a formação de cicatrizes indesejáveis e evitar o excesso de tensão entre os cotos tratados através da tubulização, melhorando os resultados funcionais.

Qualquer que seja o material do conduíte ou tubo, o mesmo precisa apresentar um nível de flexibilidade compatível com o local de reparo, ou seja, precisa conferir proteção ao nervo em regeneração durante o processo de reinervação, sendo resistente à mobilização.

Deve permanecer no local, sem se degradar por todo o período necessário para que os axônios cresçam e atinjam o órgão alvo (Hazari et al, 1999; Kitahara et al, 2000). 
Também é importante ressaltar que o material utilizado deve oferecer a menor resposta inflamatória possível, para que não crie debris ou obstáculos locais que lentifiquem o crescimento axonal ou adiram estruturas vizinhas ao sitio de reparo como, por exemplo, os tendões, propiciando déficits motores locais.

A veia jugular externa foi utilizada em vários estudos relacionados à reconstrução de nervos (Allet et al, 2003; Ulkur et al, 2003; Cunha e Costa, 2007), sendo sua anatomia amplamente conhecida.

O seu comprimento médio é de $45 \mathrm{~mm}$ (variando entre 42 a $48 \mathrm{~mm}$ ) e o seu diâmetro é variável entre 1,7 +- 0,4 mm na porção proximal e 1,4 +-0,5 mm na sua porção distal. A espessura média da parede da veia é de 250 micrômetros. Também foi demonstrado que essas medidas são compatíveis com as medidas do nervo fibular para a reconstrução em ratos (Wolff et al, 1990; Cunha e Costa, 2007).

Alguns autores relataram sucesso na reparação de nervos com o uso de enxertia de veia em seres humanos, como por exemplo, o uso em reconstrução de nervos sensitivos em defeitos com até $3 \mathrm{~cm}$ (Tang et al, 1993; Malizos et al, 1997; Nahabedian et al, 1998; Stahl et al, 1999).

Relacionou-se ao sucesso deste tipo de reparação a presença do fator de crescimento de células endoteliais (fator angiogênico), que é semelhante ao encontrado nas células de Schwann, como um dos agentes que favoreceriam a regeneração do nervo lesado. A veia também serviria como proteção ao tecido cicatricial que pudesse invadir o sitio de lesão e dificultar ou impedir a regeneração neural (Chiu et al, 1982; Suematsu et al, 1988; Chiu et al, 1990). 
Já a utilização de enxertos alógenos pode ser considerada com uma alternativa de reconstrução quando há, sobretudo, uma grande perda de tecido neural (Millesi et al, 1972).

O principal motivo para o insucesso deste procedimento seria o alto grau de antigenicidade produzido, sendo necessária a utilização de imunossupressores, sob o risco de forte rejeição local com a suspensão precoce do mesmo (Zalewski e Gulati, 1980; Lassner et al, 1989; Tuma Jr et al, 1998).

Há vários relatos na literatura cientifica sobre o efeito do FK506 como imunossupressor eficiente para uso em reparos utilizando nervos alógenos e xenógenos em estudos experimentais, mesmo quando a sua administração é temporária. (Buttemeyer et al, 1995; Hebebrand et al, 1997; Costa et al, 2006).

Uma alternativa para a não utilização dos imunossupressores seria a utilização de substâncias que além de conservarem o tecido alógeno, diminuiriam a sua antigenicidade. A conservação de tecidos em glicerol surgiu para ocupar esta lacuna.

Inicialmente a conservação em glicerol foi utilizada para conservar pele (Crawford, 1957; Granger, 1981; Friedmann, 1986; Hansbrough, 1982; Doughty et al, 1996; Ghosh et al, 1997; Farrington et al, 2002). Porém, outros tecidos foram conservados com sucesso, destacando-se dura-máter (Puig e Verginelli, 1971; Stolf e Zerbini, 1972; Haddad et al, 1973; Nogueira e Pigossi, 1973; Cavalcanti et al, 1974), vasos sanguíneos (Wolff et al, 1990; Farhner ET al, 2004) e nervos (Wolff et al, 1993). 
$\mathrm{Na}$ avaliação dos resultados histológicos, o grupo A (auto-enxertia) demonstrou a presença de escapes axonais, demonstrando que apesar da presença do epineuro e dos fatores neurotróficos locais, estes não foram capazes de dirigir todas as fibras axonais em crescimento para o órgão alvo.

Como demonstrado em vários relatos prévios na literatura cientifica, a regeneração neural não obtém a recuperação total do nervo acometido após o reparo da lesão devido a vários problemas. Dentre os principais fatores, temos: tecido cicatricial, debris, retração do epineuro, degeneração Walleriana, diminuição da quantidade de fibras mielinizadas, decréscimo do diâmetro das fibras axonais, presença de células de Schwann e interferências de estruturas próximas ao sitio de lesão e ao órgão alvo (Burnett and Zager, 2004).

Uma variação considerável entre os tamanhos dos fascículos e a presença de degeneração Walleriana, mesmo que em pequena quantidade, vai de encontro aos relatos prévios de vários autores em relação à regeneração e o uso de auto-enxertos (Wolff et al, 1990; Costa, 2006; Cunha e Costa, 2007).

Na analise histológica do Grupo B (veia autógena conservada em glicerol) foi observada uma menor reação tecidual perineural em relação ao grupo A (auto-enxertia). Esse fato provavelmente está relacionado à conservação em glicerol, que destruiu as células da camada intima da veia, bem como as células musculares da camada média, tornando-a uma estrutura de baixa antigenicidade (Wolff e Dienemann, 1990; Farhner et al, 2004).

Houve também no grupo B (veia autógena conservada em glicerol) um menor escape de axônios para fora dos limites da veia, devido provavelmente ao fato do arcabouço da veia rica em colágeno e laminina guiarem melhor o 
crescimento axonal à extremidade distal do nervo lesado (Cunha e Costa, 2007). Outro aspecto que pode ter contribuído é o fato de que a tubulização elimina a necessidade de sutura entre os cotos do nervo, determinando uma menor reação inflamatória local (Wolff et al, 1990; Costa et al, 2006; Cunha e Costa, 2007).

No grupo B (veia autógena conservada em glicerol) demonstrou a presença de mini fascículos neurais, em sua grande maioria, mielinizados e a presença de degeneração Walleriana em pequena quantidade, conforme relatos prévios na literatura científica (Wolff et al, 1990; Costa et al, 2006; Cunha e Costa, 2007).

O Grupo C (nervo alógeno conservado em glicerol) demonstrou uma baixa resposta inflamatória, caracterizada por uma reação perineural de baixa intensidade e menor se comparada ao grupo A (auto-enxertia). Também demonstrou a presença de axônios, em sua maioria mielinizados, dispostos em minifascículos, fibras neurais com grande variação de diâmetros permeados por vasos sanguíneos e degeneração Walleriana.

Foi observada uma menor quantidade de escapes para fora dos limites do nervo se comparadas ao Grupo A (auto-enxertia) e semelhante ao grupo B (veia autógena conservadas em glicerol). As explicações para esses fatos se devem às mesmas razões que as já discutidas no Grupo B.

Em relação aos dados histológicos obtidos no Grupo C (nervo alógeno conservado em glicerol) fica difícil sua comparação com dados da literatura, uma vez que o único experimento realizado com nervo alógeno conservado em glicerol a 98\% (Wolff et al 1993) foi feito com nervo femoral e não fibular como 
nesse experimento. Várias outras diferenças entre os trabalhos serão descritas a seguir e merecem destaque, tornando esse experimento singular.

Wolff et al em1993 utilizou aloenxerto de nervo preservado em glicerol a 98\% para corrigir lesão de $10 \mathrm{~mm}$ em nervo femoral de ratos. Esse experimento utilizou um nervo mais calibroso e defeitos maiores que os utilizados no experimento com o nervo fibular (lesão de $5 \mathrm{~mm}$ ), sendo necessário um tempo maior para se obter a regeneração e uma maior complexidade nas analises histológica e funcional, pela maior quantidade de fibras presentes no nervo femoral.

Vários estudos corroboram a afirmação de que experimentos realizados com nervos menos calibrosos e com função mais específica são mais fáceis de serem analisados e mais fidedignos que àqueles realizados com nervos de maior calibre em nervos periféricos de membros inferiores em estudos experimentais de ratos (Bain et al, 1989; Kerns et al, 2005; Cunha e Costa, 2007).

Outro ponto a ser considerado é a diferença entre os períodos propostos para a conservação dos aloenxertos no estudo com o nervo femoral (Wolff et al, 1993) em relação aos utilizados nesse experimento.

Wolff et al realizou seu experimento com aloenxertos de nervo femoral retirados de ratos Fisher, conservando-os em glicerol a 98\% por 100 a 147 dias em refrigeração a $4^{\circ} \mathrm{c}$ seguido por breve período de 30 minutos de imersão em solução fisiológica simples ( $\mathrm{NaCl}$ a 0,9\%). Logo após, esses segmentos foram utilizados no reparo de nervos femorais de ratos Lewis. 
Nessa dissertação, aloenxertos de nervo fibular foram retirados de ratos Sprague-Dawley e conservados em glicerol a 98\% pelo período de 7 dias em refrigeração a $4^{\circ} \mathrm{c}$ seguido por breve período de 30 minutos de imersão em solução fisiológica simples ( $\mathrm{NaCl}$ a 0,9\%). Depois, esses segmentos foram utilizados no reparo de nervos fibulares de ratos Wistar. A partir dos dados obtidos neste estudo, verificou-se que o tempo de conservação de 7 dias é suficiente para diminuir a resposta imune ao aloenxerto de nervo fibular de rato. Uma conservação eficiente para aloenxertos fibulares com um tempo pequeno de exposição ao glicerol torna esse trabalho inédito na Literatura Médica.

Em relação à avaliação funcional, realizada com a metodologia do "Walking Track Analysis" nesse estudo, os valores médios do IFF (índice de função do fibular) no pré-operatório dos três grupos avaliados não apresentaram diferença estatisticamente significativa. Esse dado permite conferir uma homogeneidade ao padrão de deambulação no pré-operatório dos 3 grupos e, posteriormente, permitir a comparação do ponto de vista funcional dos tipos de tratamento empregados para correção do defeito do nervo.

Os dados da média do IFF do pós-operatório imediato dos três grupos foram submetidos à análise estatística e não se determinou diferença estatisticamente significativa entre os grupos. Essa ausência de diferença indica que, de maneira semelhante, todos os ratos foram submetidos ao mesmo tipo de lesão neural (realizado através da ressecção de 5mm de nervo) e possibilita a comparação da recuperação funcional entre os grupos.

Com 3 e 6 semanas de pós-operatório não houve diferença estatisticamente significativa do IFF entre os 3 grupos analisados Então, 
independente do método utilizado para o tratamento do defeito do nervo, não houve diferença estatística na recuperação funcional dos animais em nenhum período avaliado.

É importante frisar que com esses dados fica plausível dizer que o glicerol diminuiu de tal sorte a antigenicidade do aloenxerto que permitiu resultados semelhantes ao da veia autógena e da própria auto-enxertia.

A análise funcional realizada no experimento de Wolff et al (1993) foi por estudo eletrofisiológico após 3 e 6 meses do pós-operatório, através de eletrodos de estimulação e de leitura distando $2,5 \mathrm{~cm}$ entre si, localizados no músculo quadríceps femoral, com o registro de 20 potenciais de ação muscular Calculou-se então a média desses potenciais para cada rato do estudo. Não houve diferença estatisticamente significativa entre o grupo da auto-enxertia e do aloenxerto. $(p<0.05)$.

Apesar das metodologias de avaliação e os nervos serem diferentes, nos dois trabalhos não se evidenciou diferença estatisticamente significativa do ponto de vista funcional entre a reparação realizada com auto-enxertia e com o aloenxerto.

Faz-se necessária a pesquisa contínua por alternativas viáveis a autoenxertia de nervos. As perspectivas em relação aos tecidos conservados em glicerol são cada vez melhores, pois demonstraram baixa antigenicidade, baixo custo, facilidade de manipulação e de preparo.

A oportunidade de se utilizar aloenxertos de nervos com características estruturais muito similares aos dos auto-enxertos e com recuperação funcional semelhante à obtida com esse tratamento, torna-se alternativa extremamente 
vantajosa na reparação de nervos periféricos com perda de substância. A fonte de um tecido que não se esgota encoraja ainda mais que novas pesquisas sejam realizadas nessa linha de pensamento. 


\section{CONCLUSÕES}

Baseado na análise histológica e na avaliação funcional da regeneração neural obtida para a correção de defeitos de $5 \mathrm{~mm}$ em nervos fibulares de Ratos Wistar em cada um dos grupos estudados (Grupo A- Auto-enxertia de nervo; Grupo B- Veia autógena conservada em glicerol e Grupo C-Nervo alógeno conservado em Glicerol, pode-se concluir que:

1 - Análise Histológica:

A- Em todos os grupos observaram-se pequenos fascículos contendo axônios mielinizados e de tamanhos variados e degeneração Walleriana em pequeno número de axônios.

B- Nos grupos B (Veia autógena conservada em glicerol) e C(Nervo alógeno conservado em glicerol) o escape de fibras axonais mielinizadas para fora dos limites do epineuro que foi menor que o do grupo A (Auto-enxertia).

C- Nos grupos B (Veia autógena conservada em glicerol) e C (Nervo alógeno conservado em glicerol) houve a formação de um processo inflamatório menos intenso quando comparado ao grupo A (Autoenxertia)l. 
2 - Avaliação Funcional:

A- Não houve diferença estatisticamente significativa entre as recuperações funcionais do nervo fibular independente do tipo de reparação utilizada: auto-enxertia, veia autógena conservada em glicerol e nervo alógeno conservado em glicerol. 


\section{REFERÊNCIAS BIBLIOGRÁFICAS}

Allet MA, Leite VM, Albertoni WM, Fernandes FAZ, Fernandes M, Faloppa F. Enxerto "versus" enxerto coberto com tubo de veia nas reparações nervosas. Rev Bras Ortop. 2003; 38: 194-200.

Ashur $H$, Vilner $Y$, Finsterbusch $A$, Rousso $M$, Weinberg $H$, Devor M. Extent of fiber regeneration after peripheral nerve repair: silicone splint vs. suture, gap repair vs. graft. Exp Neurol. 1987; 97: 365-74.

Bain JR, Mackinnon SE, Hudson AR, Falk RE, Hunter DA. The nerve allograft response in the rat immunosuppressed with cyclosporin. Plast Reconstr Surg. 1988; 82: 1052-64.

Bain JR, Mackinnon SE, Hunter DA. Functional evaluation of complete sciatic, peroneal, and posterior tibial lesions in the rat. Plast. Reconstr. Surg. 1989; 83: 129-36.

Ballance $\mathrm{C}$, Duel $\mathrm{AB}$. The operative treatment of facial palsy by the introduction of nerve grafts into the fallopian canal and by other intratemporal methods. Arch Otolaryngol. 1932; 15:1.

Barbin G, Manthorpe M, Varon S. Purification of the chick eye ciliary neuronotrophic factor. J Neurochem. 1984; 43:1468-1478.

Bassett CAL , Campbell JB, Husby J. Peripheral nerve and spinal cord regeneration technique employing millipore. Exp Neurol. 1959; 1: 386-406. 
Bignami A, Chi N, Dahl D. Laminin in rat sciatic nerve undergoing Wallerian degeneration. Neuropath Exp Neurol. 1984; 43:94-103.

Braga-Silva J. The use of silicone tubing in the late repair of the median and ulnar nerves in the forearm. J Hand Surg [Br]. 1999; 24(6): 703-6.

Brunelli GA. Hyaluronic Acid tubes (in biodegradable tubes section). Symposium: peripheral nerve surgery today. Wien; Algemeines Krankenhaus, 1991.

Brunelli GA, Vigasio A, Brunelli GR. Different conduits in peripheral nerve surgery. Microsurg. 1994; 15: 176-8.

Brunelli GA, Milanesi S, Fontana G, Bartolaminelli P. Invaginamento di segmenti venosi di lesioni nervose. In Congress Societa Italiana Ricerche di Chirurgia, Palermo, 1982.

Brunelli GA, Fontana G, Jaeger C, Bartolaminelli P.Franchini A. Chemotactic arrangement of axons inside and distal to a venous graft. $\mathrm{J}$ Reconstr. Microsurg. 1987; 3: 87-9.

Brunelli GA, Battiston B, Vigasio A, Brunel IGR, Marocolo D. Briding nerve defects with combined skeletal muscle and vein conduits. Microsurg. 1993; 14: 247-51.

Brushart TM, Seiler WA. Selective reinnervation of distal motor stumps by peripheral motor axons. Exp Neurol. 1987; 97:289-300. 
Bryan DJ, Miller RA, Costas PD, Wang KK, Seckel BR. Immunocytochemistry of skeletal muscle basal lamina grafts in nerve regeneration. Plast. Reconstr. Surg. 1993; 92: 927-40.

Bryan DJ, Hekemian KJ, Wang KK, Chakali DP, Seckel BR. Effect of Schwann cells in the microenvironment of regenerating nerves. Surg Forum. 1993; 44:712-14.

Burnett MG, Zager EL. Pathophysiology of peripheral nerve injury: A brief review. Neurosurg Focus. 2004; 16(5).

Buttemeyer R, Rao U, Jones NF. Peripheral nerve allograft transplantation with FK506: functional, histological and immunological results before and after discontinuation of immunosuppression. Ann Plast Surg. 1995; 35: 396-401.

Carter AJ, Kristmundsdottir F, Gilmour J, Glasby MA. Changes in muscle cytoarchiteture after peripheral nerve injury and repair. Journal of Hand Surgery. 1998; 23: 365-369.

Chen YS, Wang-Bennett LT, Cocker NJ. Facial nerve regeneration in the silicone chamber: the influence of nerve growth factor. Exp Neurol. 1989; 103:52-60.

Chiu DT, Janecka I, Krizek TJ, Wolff M, Lovelace RE. Autogenous vein graft as a conduit for nerve regeneration. Surgery. 1982; 91: 226-33.

Colin W, Donoff RB. Nerve regeneration through collagen tubes. J. Dent. Res. 1984; 63: 987-93. 
Colohan AR, Pitts LH, Rosegay H. Injury to the peripheral nerves. In: Feliciano DV, Moore EE, Mattox KL. Eds trauma. 3rd Ed. Stamford, Conn: Appleton \& Lange. 1996: 853-62.

Costa MP. Tubo de ác. poliglicólico e Fr506 na regeneração de nervos periféricos [Tese]. São Paulo: Faculdade de Medicina, Universidade de São Paulo; 2001.

Costa MP, Cunha AS, Silva CF et al. A utilização do tubo de ácido poliglicólico e FK506 na regeneração de nervos periféricos. Acta ortop brás , 2006; 14; 1; 25-29.

Costa MP. Emprego do tubo de ác. poliglicólico como substituto de enxerto de nervo: estudo experimental em ratos [Dissertação]. São Paulo: Faculdade de Medicina, Universidade de São Paulo; 1998.

Crawford H. Dura replacement: an experimental study of derma autografts and preserved dura homografts. Plastic and Reconstructive Surgery. 1957; 19: 29.

Cunha AS, Lemos SPS, Silva CFS, Barros Filho TEP, Costa MP, Ferreira MC. Utilização da veia glicerolada na regeneração neural: estudo experimental em ratos. Acta Ortop Bras. 2007; 15(4): 210-213.

Davies AN, DE Souza BA, Gattuso JM, Glasby MAM, Gschmeissner SE, Huang CLH. Peripheral nerve growth through differently oriented muscle matrices. Neuro-Orthpaedics. 1987; 4:62-73.

Davison SP, Mccaffrey TV, Porter N, Manders E. Improved nerve regeneration with neutralization of transforming growth factor beta-1. The Laryngoscope. 1999; 109: 631. 
De Medinaceli L, Freed WJ, Wyatt RJ. An index of the functional condition of rat sciatic nerve based on measurements made from walking tracks. Exp. Neurol. 1982; 77: 469-87.

De Medinaceli L ,Seaber AV. Experimental nerve reconnection: importance of initial repair. Microsurgery. 1989; 10:56-70.

Dellon Al, Mackinnon SE. An alternative to the classical nerve graft for the management of the short nerve gap. Plast Reconstr Surg. 1988; 82:849-56.

Denny-Brown D, Doherty MM. Effects of transient stretching of peripheral nerve. Arch Neurol Psyc. 1945; 54:116-29.

Dodd J, Jessell TM. Axon guidance and the patterning of neuronal projections in vertebrates. Science. 1988; 242:692-699.

Doolabh V, Mackinnon SE. FK506 accelerates functional recovery following nerve grafting in a rat model. Plast Reconstr Surg. 1999; 103: 1928.

Doughty M.J., Aakre B.M. and Patel S. 1996. Hydration (water binding) of the mammalian corneal stroma ex vivo and in vitro: sample mass and error consideration. Optometry and Visual Science 73: 666-675.

Dych PJ, Lofgren EP. Nerve biopsy - choice of nerve, methods, symptoms, and usefulness. Medical Clin North Am. 1968; 52:878-85.

Eppley BL, Delfino JJ. Collagen tube repair of the mandibular nerve a preliminary investigation in the rat. J. Oral Maxillofac. Surg. 1988; 46: 41-7. 
Fansa H, Keilhoff G, Altmann S, Plogmeier K, Wolf G, Schneider W. The effect of the immunosuppressant FK506 on peripheral nerve regeneration following nerve grafting. Journal of Hand Surgery. 1999; 24: 38-42.

Farhner PJ, Idu MM, Legemate DA, Vanbavel E, Borstlap J, Pfaffendorf $M$, Van Marle J, Van Gulik TM . Morphological and functional alterations in glycerol preserved rat aortic allografts. Int J Artif Organs. 2004; 27(11): 979-989.

Fawcett WJ, Keynes RJ. Muscle basal lamina: a new graft material for peripheral nerve repair. J Neurosurg. 1986; 65: 354-363.

Ferreira MC, Herson MR. 2000. Tissue banking. Latin America Cir. Plast. FMUSP. São Paulo. 2000; 8: 1.

Fields RD, Lebeau JM, Longo FM, Ellisman HN. Nerve regeneration through artificial tubular implants. Prog Neurobiol. 1989; 33: 87-134.

Fiolova MA. Effect of glycerol preservation on the immunogenic properties of dura-mater. Eksp Khir Anesteziol. 1976; 6: 3.

Foramitti C. Zur technik der nervennaht. Archivium Klinik Chirurgie 1904; 73: 643-8.

Friedmann PS. The skin as a permeability barrier. In: Thody A.J. and Friedmann P.S. (Eds), Scientific Basis of Dermatology. New York: Churchill Livingston. 1986

Gabrielson GJ, Stenstrom SJ. A contribution to peripheral nerve suture technique. Plast Reconstr Surg. 1966; 38: 68-72. 
Garrity RW. The use of plastics and rubber tubing in the management of irreparable nerve injuries. Surgical Forum. 1955; 6: 517-20.

Gattuso JM, Glasby MA, Gschmeissner SE, Huang CLH. Recovery of neuromuscular transmission following peripheral nerve repair with muscle autografts in the non-human primate. J Bone Joint Surg. 1988; 70b: 524-29.

Ghosh MM, Boyce S, Layton C, Freelander E and Macneil S. 1997. A comparison of methodologies for the preparation of human epidermal-dermal composites. Annals of plastic Surgery 39: 390-404.

Giorgio AB, Bruno B, Adolfo V, Giovanni B, Marocolo D. Bridging nerve defects with combined skeletal muscle and vein conduits. Microsurg. 1993; 14: 247-51.

Glasby MA, Hitchcock RJ, Huang CLH. The effect of muscle basement membrane on the regeneration of rat sciatic nerve. J Bone Joint Surg. 1986; 68b: 829-33.

Glück T. Ueber Neuroplastik auf dem Wege der Transplantation. Archivium Klinik Chirurgie 1880; 25: 606-66.

Gould JSP. "Digital Nerves" in Gelberman, RH. Operative Nerve Repair and Reconstruction. JB Lippincott Co. 1991: 458.

Granger H.J. 1981. Physicochemical properties of the extracellular matrix. In: Hargens A.R. (ed.), Tissue Fluid Pressure and Composition, Williams \& Wilkins Waverly Press Inc., Baltimore, pp. 43-61.

Gundersen RW, Barrett JN. Characterization of the turning response of dorsal root neuritis toward nerve growth factor. J Cell Biol. 1980; 87: 546-554. 
Hansbrough J.D. 1992. Wound Coverage with Biologic Dressings and Cultured Skin Substitutes, RG Lands Company, Austin, pp. 1-8.

Hazari A, Wiberg M, Johansson-Ruden G, Green C, Terenghi G. A resorbable nerve conduit as an alternative to nerve autograft in nerve gap repair. British $\mathrm{J}$. Plast. Surg. 1999; 52: 653-7.

Hebebrand D, Zohman G, Jones NF. Nerve xenograft transplantation immunosuppression with FK-506 and RS-61443 . J Hand Surg [Br]. 1997 ; 22(3): 304-7.

Hentz VR, Rosen JM, Xiao SJ, McGILL KC, Abraham G. A comparison of suture and tubulization nerve repair technique in a primate. J. Hand Surg. 1991; 16a: 251-61.

Herson MR, Mathor MB, Ferreira MC. Bancos de Pele I. Revista Brasileira de Queimaduras. 2002; 1: 35-40.

Heuter K. Die Allgemeine Chirugie. Leipzig. Vogel verlag. 1873.

Ide C, Osawa T, Tohyama K. Nerve regeneration through allogeneic nerve grafts with special reference to the role of the Schwann cell basal lamina. Prog Neurobiol. 1990; 34; 1-38.

Ide C, Tohyama K, Yotoka R, Nitatori T, Onodera, S. Schwann cell basal lamina and nerve regeneration. Brain Res. 1983; 288: 959-62.

ljpma FF, Nicolai JP, Meck MF. Sural nerve donor-site morbidity: thirty-four years of follow-up. Ann Plast Surg. 2006; 57(4): 391-5. 
Jacobson $\mathrm{JH} 2^{\text {nd }}$. Microsurgical technik in repair of the traumatized extremity. 1963. Clin Orthop Relat Res. 1995; 314: 4-7.

Jacques L, Kline DG: Response of the peripheral nerve to physical injury, Crockard A, Hayward R, Hoff JT (Eds): Neurosurgery: The Scientific Basis of Clinical Practice, Ed 3. London: Blackwell. 2000; 1: 516-525.

Jaffe LF, Poo MM. Neuritis growth faster towards the cathode than the anode in a steady field. J Exp Zool. 1979; 209: 115-128.

Jimming K, Shizhen Z, Bo S, Shengxiu Z. Experimental study of bridging the peripheral nerve gap with skeletal muscle. Microsurg. 1986; 7: 183-189.

Kayikçioglu A, Karamursel S, Agaoglu G, Sargon M. A new epineural nerve repair technique: Oblique nerve cooptation. Ann Plast Surg. 1999; 32: 506-12.

Keeley R, Atagi T, Sahelmann E, Padilla J, Kadlcik S, Keeley S, Keeley A, Nguyen K, Rosen J. Peripheral nerve regeneration across 14mm gaps: a comparison of autograft and entubulation repair method in the rat. J. Reconstr. Microsurg. 1993; 9: 349-59.

Keeley RD, Nguyen KD, Sthephanides MJ, Padilla J, Rosen JM. The artificial nerve graft: a comparison of blended elastomer-hydrogel with polyglicolic acid conduits. J Reconstr Microsurg. 1991; 7: 93-100.

Kirk EG, Lewis D. Fascial tubulization in the repair of nerve defects. JAMA 1915; 65: 486-92. 
Kitahara AK, Nishimura Y, Shimizu Y, Endo K. Facial nerve repair accomplished by interposition of a collagen nerve guide. J. Neurosurg. 2000; 93:113-20.

Koerber HR, Seymour AW, Mendell LM. Mismatches between peripheral receptor type and central projections after peripheral nerve regeneration. Nuerosci Lett. 1989; 99: 67-72.

Kristensson K. Retrograde signaling of nerve cell body response to trauma. In Gorio A, Millesi H, Mingrino S. Eds: Posttraumatic Peripheral Nerve Regeneration. New York: Raven Press.1981. p. 27-34.

Lander Ad, Fuji DK, Rechardt LF. Laminin is associated with " neuritis outgrowth-promoting factors" found in conditioned media. Proc. Natl. Acxad. Sci. USA. 1985; 82: 2183-7.

Laskowski S. L'embaument, la conservacion des sujets et les preparations anatomiques. Geneve. 1885.

Levi-Montalcini R, Hamburger V .Selective growth stimulating effects of mouse sarcoma on the sensory and sympathetic nervous system of the chick embryo. J Exp Zool. 1951; 116:321-361.

Lewis T, Pickering GW, Rothschild P. Centripetal paralysis arising out of arrested bloodflow to the limb. Heart. 1931; 16: 1-32.

Lundborg G, Dahlin LB, Danielsen NP. Hansson HA. Larsson K. Reorganisation and orientation of regenerating nerve fibers, perineurium and epineurium in preformed mesothelial tubes- An experimental study on the sciatic nerve of rats. J. Neurosc. Res. 1981; 6: 265-81. 
Lundborg G, Dahlin LB, Danielsen N, Hasson HA, Johannesson A, Longo FM, Varon S. Nerve regeneration across an extended gap: a neurobiological view of nerve repair and the possible involviment of neuronotrophic factors. J. Hand Surg. 1982; 7: 580-7.

Lundborg G, Dahlin LB, Danielsen N, Gelberman RH, Longo FM, Powell HC, Varon S. Nerve regeneration in silicone chambers: influence of gap length and distal stump components. Exp. Neurol. 1982; 76: 361-75.

Lundborg G, Dahlin LB, Danielsen NP. Hansson HA. Larsson K. Reorganisation and orientation of regenerating nerve fibers, perineurium and epineurium in preformed mesothelial tubes- An experimental study on the sciatic nerve of rats. J. Neurosc. Res. 1981; 6: 265-81.

Lundborg G, Dahlin LB, Danielson N, Nachemson, AK. Tissue specificity in nerve regeneration. Scan J Plast Surg. 1986; 20; 279-83.

Lundborg G, Gelberman RH, Longo RM. In vivo regeneration of cut nerves encased in silicone tubes: growth across a six millimeter gap. J Neurophatol Exp Neurol. 1982; 41: 412-22.

Lundborg G, Longo FM, Varon S. Nerve regeneration model and trophic factors in vivo. Brain Res. 1982; 232: 157.

Mackinnon SE, Dellon AL. Clinical nerve regeneration with a bioabsorbable polyglicolic acid tube. Plast. Reconstr. Surg. 1990; 85: 419-24.

Mackinnon SE, Dellon AL. A study of nerve regeneration across synthetic (Maxon) and biologic (collagen) nerve conduits for nerve gaps up to $5 \mathrm{~cm}$ in the primate. J Reconstr Microsurg. 1990; 6: 117-121. 
Mackinnon SE, Dellon AL. Experimental study of chronic nerve compression: Clinical implications. Clinics in Hand Surgery. 1986 2: 639-50.

Mackinnon SE, Dellon AL. Surgery of the peripheral nerve. 1988; 1: 1-33.

Mackinnon SE, Dellon AL. Surgery of the peripheral nerve. Thieme Publishing. 1988; $1: 121$.

Mackinnon SE, Dellon AL. Clinical nerve reconstruction with bioabsorbable polyglicolic acid tube. Plast Reconstr Surg. 1990; 85: 419-24.

Mackinnon SE, Dellon AL, Hudson AR, Hunter DA. Chronic nerve compression: An experimental model in the rat. Annals of Plastic Surgery. 1984; 13:112-120.

Mackinnon SE, Dellon AL, Hudson AR, Hunter DA. A primate model for chronic nerve compression. Journal of Reconstructive Microsurgery. 1985; 1:185-94.

Mackinnon SE, Dellon AL, Hudson AR, Hunter DA. A study of neurotropismo in the primate model. J Hand Surg. 1986; 11: 888-894.

Madison R, DA Silva CF, Dikkes P, Chiu TH, Sidman RL. Peripheral nerve regeneration with entubulization repair; Comparison of biodegradable nerve guides vs. polyetilene tubes and effects of a laminina- containing gel. Exp Neurol. 1987; 95: 378-390.

Madison R, DA Silva CF, Dikkes P. Entubulation repair with protein additives increases the maximum nerve gap distance successfully bridged with tubular prostheses. Brain Res. 1988; 96: 325-334.

Maki Y. Selectivity of regenerating motor axons. In Symposium: Peripheral Nerve Surgery Today. Wien; Algemeines Krankenhaus. 1991. 
Marshall L, Gosh MM, Boyce SG, Macneil S, Freedlander E, Kudesia G. Effects of glycerol on intracellular virus survival: implications for the clinical use of glycerol-preserved cadaver skin. Burns 1995; 21:356-361.

Mattar Jr R, Azze RJ, Ferreira MC, Zumiotti AV. Fibrin glue versus conventional epineural suture for peripheral nerve repair. A comparative experimental study. Rev Soc Brás Cir Plast. 1990; 5: 34-9.

Mattar Jr R, Starck R, Guarnieri MV, Azze RJ, Witteldorf CS, Ferreira MC. Utilização de enxerto de nervo de membrane basal de fibra muscular estriada para a reparação de lesões de nervos periféricos: estudo experimental. Ver Bras Ortop. 1990; 25: 287-91.

Malizos KN, Dailiana ZH, Anastasiou EA, Sarmas I, Soncacos PN. Neuromas and gaps of sensory nerves of the hand: management using vein conduits. Am J Orthop. 1997; 26(7): 481-5.

Millesi H. Progress in peripheral nerve reconstruction. W. J. Surg. 1990; 14:73347.

Millesi $\mathrm{H}$. Treatment of nerve lesions by fascicular free nerve grafts. In Michon j, and Moberg E. (Eds): Traumatic nerve lesions. Edinburg: Churchill Livingstone. 1975.

Mohammad J, Shenaq J, Rabinovsky E, Shenaq S. Modulation of peripheral nerve regeneration: a tissue-engineering approach. The role of amnion tube nerve conduit across a 1 centimeter nerve gap. Plast Reconstr Surg. 2000; 105: 660. 
Molander H, Engkvist O, Hagglund J, Olsson Y, Torebjorg E. Nerve repair using a polyglactin tube and nerve graft: an experimental study in the rabbit. Biomaterials. 1983; 4: 276-280.

Molander $\mathrm{H}$, Olsson $\mathrm{Y}$, Engkvist $\mathrm{O}$. Regeneration of peripheral nerve through a polyglactin tube. Muscle Nerve. 1982; 5: 54-7.

Molander $\mathrm{H}$, Olsson $\mathrm{Y}$, Engkvist $\mathrm{O}$, Bowald S, Eriksson I. Regeneration of peripheral nerve through polyglactin tube. Muscle Nerve. 1982; 5: 54-57.

Muller $\mathrm{H}$. Further evaluation of laminina, testosterone, ganglioside GM-1, and catalase on early growth in rat nerve regeneration chambers. Exp Neurol. 1988; 101: 228-233.

Nahabedian MY, Sinder Jr. Successful reinnervation of the penis using Autogenous vein conduits. J Reconstr Microsurg. 1998; 14(1): 31-33.

Nyilas E, Chiu TH, Sidman RL. Synthetic bioresorbable polymers: 1. Polyester and polyester-composite guidance channels for peripheral nerve repair. Trans Am Soc Artif Intern Organs. 1983; 6: 85.

Ochi M, Fukuhara K, Chow SP, Ikuta Y. An experimental study on selective sensory and motor nerve regeneration in silicone $\mathrm{Y}$ chamber. In Symposium: Peripheral Nerve Surgery Today. Resumenes. Wien; Algemeines Krankennhaus. 1991.

Ortiguela ME, Wood MB, Cahill DR. Anatomy of the sural nerve complex. J Hand Surg. 1987; 12: 19-23. 
Otto D, Unsicker K, Grothe C. Pharmacological effects of nerve growth factor and fibroblast growth factor applied to the transectioned sciatic nerve on neuron death in adult rat dorsal root ganglia. Neurosci Lett. 1987; 83:156-160.

Patel N, Poo MM. Orientation of neuritis growth by extracellular electric fields. J Neurosci. 1982; 2: 483-496.

Perry JR, Bril V. Complications of sural nerve biopsy in diabetic versus nondiabetic patients. Can J Neuro Sci. 1994; 21: 34-7.

Pham HN, Padila JA, Nguyen KD, Rosen JM. Comparison of nerve repair techniques: suture vs. avitene-polyglicoic acid tube. J. Reconstr. Microsurg. $1991 ; 7: 31-6$.

Pigossi N. A glicerina na conservação de dura-máter: estudo experimental. [Livre Docência]. 1967. São Paulo: Faculdade de Medicina da Universidade de São Paulo.

Puburski R, Malin JP, Stark E. Sequelae of sural nerve biopsies. Clin Neurol Neurosurg. 1985; 87:193-99.

Politis MJ, Ecerle K, Spencer PS. Tropism in nerve regeneration in vivo, attraction of regenerating axons by diffusable factors derived from cells in distal nerve stump of transected peripheral nerves. Brain Res.1982; 253: 1-12.

Politis M, Zanakis MF, Albala BJ. Facilitated regeneration in the rat peripheral nervous system using applied electric fields. J Trauma. 1988; 28: 1375-1381. 
Rappaport WD, Valente J, Hunter GC, Rance NE, Lick S, Lewis T, Neal D. Clinical utilization and complications of sural nerve biopsy. Am J Surg. 1993; 166: 252-56.

Rice $\mathrm{DH}$, Berstein FD> the use of Autogenous vein for nerve grafting. Otolaryngol Head Neck Surg. 1984; 92: 410-412.

Rich KM, Alexander TD, Pryor JC, Hollowell JP. Nerve growth factor enhances regeneration through silicone chambers. Exp Neurol. 1989; 105: 162-170.

Robinson PH, Vanderlei B, Pennings AJ, Neiwenhuis P. Nerve regeneration through a two-ply biodegradable nerve guide in the rat and the influence of ACTH4-9 nerve growth factor. Microsurg. 1993; 14: 30.

Rosen JM, Hentz VR, Kaplan EN. Fascicular tubulization: a cellular approach to peripheral nerve repair. Ann Plast Surg. 1983; 11: 397.

Sabates FN. Experimental and clinical studies of glycerin preserved sclera's homografts: a preliminary report. Eye Ear and Nose Throat. 1967; 46:1162.

Salvi V. Problems connected with the repair of nerve sections. Hand. 1983; 5: $25-32$.

Sanes J, Marshall LM, Mc Mahan UJ. Reinnervation of muscle fiber basal lamina after removal of myofibres. Differentiation of regenerating axons at original synaptic sites. J Cell Biol. 1978; 78: 176-98.

Seckel BR, Chiu TH, Nyilas E, Sidman RL. Nerve regeneration synthetic biodegradable nerve guides: regulation by the target organ. Plast Reconstr Surg. 1984; 74: 173-181. 
Seckel BR, Ryan SE, Gagne RJ. Target specific nerve regeneration through a nerve guide in the rat. Plast Reconstr Surg. 1986; 78; 793-798.

Seckel BR: Enhancement of peripheral nerve regeneration. Muscle Nerve. $1990 ; 13: 785-800$.

Seddon HJ. The use of Autogenous grafts for the repair of large gaps in peripheral nerves. Br J Surg. 1947; 35: 151-167.

Slack JR, Hopkins WG, Pockett S. Evidence for a motor nerve growth factor. Muscle Nerve. 1983; 6:243-252.

Smith JW. Microsurgery of peripheral nerves. Plast Reconstr Surg. 1964; 33: 317-329.

Spector JG, Lee P, Derby A, Frierdich GE, Neises G, Roufa DG. Rabbit facial nerve regeneration in NGF-containing Silastic tubes. Laryngoscope. 1991; 101: $537-554$.

Spector JG, Lee P, Derby A, Frierdich GE, Roufa DG. Early stages of facial nerve regeneration through silicone chambers in the rabbit. Laryngoscope. 1991; 101: 1109-1123.

Spector JG, Lee P, Derby A, Frierdich GE, Neises G, Roufa DG. Rabbit facial nerve regeneration in ngf-containing Silastic tubes. Laryngoscope. 1993; 103: 548-58.

Spector JG, Lee P, Derby A, Roufa DG. Comparison of rabbit facial nerve regeneration in NGF-containing silicone tubes to that in autologous neural grafts. Ann. Otol. Rhinol. Laryngol. 1995; 104: 875-85. 
Stahl S, Rosenberg N. Digital nerve repair by Autogenous vein graft in highvelocity gunshot wounds. Mil Med. 1999; 164(8): 603-4.

Stancic MF, Micovic V, Potocnjak M, Draganic P, Sasso A, Mackinnon SE. The value of an operating microscope in peripheral nerve repair. International Orthopaedics. 1998; 22: 107-110.

Staniforth P, Fisher TR. The effects of sural nerve excision in Autogenous nerve grafting. Hand .1978; 10: 187-90.

Stensaas L, Bloch LM , Garcia R, Sotelo J. Snug tubular enclosures reduce extrafascicular axonal escape at peripheral nerve repair sites. Exp Neurol. 1989; 103: 135-145.

Sunderland S. Nerves and nerves injuries. New York: Churchill Livingstone. 1978.

Sunderland S. The intraneural topography of the radial, median and ulnar nerves. Brain. 1945; 68: 243-298.

Sunderland S. The anatomy and physiology of nerve injury. Muscle Nerve $.1990 ; 13: 771-784$.

Swan JJ. Discussion on injuries to the peripheral nerves. Proc R Soc Med. 1941; 34: 521-532.

Takahashi M, Statou T, Hashimoto S. Experimental in vivo regeneration of peripheral nerve axons and perineurium guided by resorbable collagen film. Acta Patol Jpn. 1988; 38: 1489-1502. 
Tang JB, Gu Y, Song YS. Repair of digital nerve defect with autogenous vein graft. Hand. Baltimore: Williams \& Wilkins. 1981.

Tang JB, Gu Y, Song YS. Repair of digital nerve defect with autogenous vein graft during flexor tendon surgery in zone 2. J Hand Surg[Br]. 1993; 18(4): 44953.

Taniuchi M, Clark HB, Schweitzer JB, et al. Expression of nerve growth factor receptors by Schwann cells of axotomized peripheral nerves: ultrastructural location, suppression by axonal contact, and binding properties. J Neurosci. 1988; 8:664-68.

Terzis JK, Faibisoff B, Williams HB. The nerve gap: suture under tension vs. graft. Plast Reconstr Surg. 1975; 56: 166-170.

Terzis JK, Kostas I. Vein graft used as nerve conduits for obstetrical brachial plexus palsy reconstruction. Plast Reconstr Surg. 2007; 120(7): 1930-41.

Tuma Jr P. Estudo comparativo da regeneração após aloenxertos de nervo, com e sem imunossupressão. Estudo Experimental [Tese]. São Paulo: Faculdade de Medicina da Universidade de São Paulo. 1997.

Ulkur E, Yukel F, Açikel C, Okur I, Celizos B. Comparison of functional results of nerve graft, vein graft, and vein filled with muscle graft in end-to-side neurorrhaphy. Microsurgery. 2003; 23(1): 40-8. 
Valentini RF, Aerbischer P, Winn SR, Galletti PM. Collagen and laminina containing gels impede peripheral nerve regeneration through semipermeable nerve guidance channels. Exp Neurol. 1987; 98: 350-356.

Varon SS, Bunge RP. Trophic mechanisms in the peripheral nervous system. Annu Rev Neurosci. 1978; 1:327-361.

Varon SS, Adler R. Nerve growth factors and control of nerve growth. Curr Top Dev Biol. 1980; 16; 207.

Waller A, Experiments on the section of the glossopharyngeal and hypoglossal nerve of frog and observations on the alterations produced thereby in the structure on their primitive fibers. Philosophical Transactions of the Royal Society of London. 1850; 140: 423-429.

Walton RL, Brown RE, Matory WE, Borah GL, Dolph JL. Autogenous vein graft repair of digital nerve defects in the finger: a retrospective clinical study. Plast. Reconstr. Surg. 1989; 84: 944-52.

Wang KK, Costas PD, Bryan DJ, Johns DS, Seckel BR. Inside-out vein graft promotes nerve regeneration in rats. Microsurg. 1993; 14: 608-18.

Wang KK, Costas PD, Bryan DJ, Eby PL, Seckel BR. Inside-out vein graft repair compared with grafting for nerve regeneration in rats. Microsurg. 1995; 16: 6570.

Weber RA, Warner MR, Verheyden CN, Proctor WH. Functional evaluation of gap vs. abutment repair of peripheral nerves in the rat. J Reconstr Microsurg. 1996; 12: 159-63. 
Weiss P. Nerve reunion with sleeves of frozen-dried artery in rabbits, cats and monkeys. Proc Soc Exp Biol 1943; 54: 274-7.

Winer BJ. Statistical Principles in Experimental Design. $2^{\text {nd }}$ ed. Tokyo: McGrawHill.1971.

Wise AJ, Topuzlu C, Davis P, Kaye IS. A comparative analysis of macro and microsurgical neurorrhaphy techniques. Am J Surg. 1969; 117: 566-572.

Wolff KD, Dienemann D. Vessel preservation with glycerol: an experimental study in rats. J Oral Maxillofac Surg. 1990; 48: 914-8.

Wolff KD, Walter G, Zimmer C. Nerve reconstruction with glycerol-preserved allogenic grafts in the rat. Microsurgery. 1993; 14: 315-22.

Wrede L. Uberbrueckung eines nervaendefeecktes mitteis seidennant und leben venenstueckes. Deutsches Medezin Wochenschrift. 1909; 35: 1125.

Yan Q, Elliott J, Snider WD: Brain-derived neurotrophic factor rescues spinal motor neurons from axotomy-induced cell death. Nature. 1992; 360:753-755.

Yan Q, Mathelson C, Lopez OT. In vivo neurotrophic effects of GDNF on neonatal and adult facial motor neurons. Nature. 1995 ; 373: 341-344.

Yin Q, Kemp GJ, Frostick SP: Neurotrophins, neurones and peripheral nerve regeneration. J Hand Surg Br. 1998; 23: 433-437. 
Yin Y, Cui Q, Li Y, Irwin N, Fisher D, Harvey AR, Benowitz Li. Macrophagederived factors stimulate optic nerve regeneration. J Neurosci. 2003; 23(6): 2284-93. 